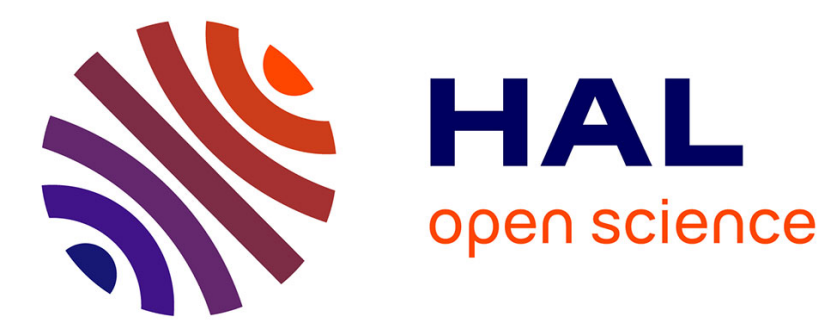

\title{
The Effects of Restrictive Measures on Cross-Border Investment: Evidence from OECD and Emerging Countries
}

Amara Zongo

\section{- To cite this version:}

Amara Zongo. The Effects of Restrictive Measures on Cross-Border Investment: Evidence from OECD and Emerging Countries. 2021. hal-03432663

\author{
HAL Id: hal-03432663 \\ https://hal.science/hal-03432663 \\ Preprint submitted on 17 Nov 2021
}

HAL is a multi-disciplinary open access archive for the deposit and dissemination of scientific research documents, whether they are published or not. The documents may come from teaching and research institutions in France or abroad, or from public or private research centers.
L'archive ouverte pluridisciplinaire HAL, est destinée au dépôt et à la diffusion de documents scientifiques de niveau recherche, publiés ou non, émanant des établissements d'enseignement et de recherche français ou étrangers, des laboratoires publics ou privés.

\section{(c)(1)}

Distributed under a Creative Commons Attribution| 4.0 International License 


\section{BORDEAUX ECONOMICS WORKING PAPERS}

\section{CAHIERS D'ECONOMIE DE BORDEAUX}

\section{The Effects of Restrictive Measures on Cross-Border Investment: Evidence from OECD and Emerging Countries}

\section{Amara ZONGO}

University of Bordeaux, LAREFI, avenue Léon Duguit, 33608 Pessac amara.zongo@u-bordeaux.fr

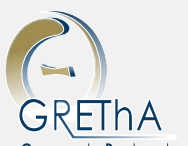

GREThA

Groupe de Recherche en
conomie Théorique et Appliquée
GREThA UMR CNRS 5113

Université de Bordeaux Avenue Léon Duguit 33608 Pessac - France Tel : +33 (0)5.56.84.25.75 http://gretha.u-bordeaux.fr/ larefi LAREFI

Université de Bordeaux Avenue Léon Duguit 33608 Pessac - France Tel : + 33 (0) 5.56.84.25.37 http://larefi.u-bordeaux.fr/ 


\section{Abstract}

This paper investigates the effects of global and sectoral restrictive measures on cross-border FDI among 49 advanced and emerging countries. We use a gravity model with panel data from 2010 to 2019 and the FDI Restrictiveness Index of the OECD that quantifies the level of restriction in FDI. Our results suggest that global restrictive measures do not significantly affect cross-border FDI in OECD countries, while restrictions in the service sector have negative and significant effects on FDI. Moreover, the overall restrictive measures and those in the service sector negatively impact inward FDI among OECD and big emerging countries. In addition, restrictions in the services sector impede inward FDI in African countries. Interestingly, restrictions in the secondary sector boost FDI between advanced and African countries, with larger effects for inward investments in African countries. The analysis of disaggregated sectoral restrictive measures shows that restrictions in business and other financial services are negatively associated with intra-OECD FDI, while restrictions in the banking sector have a significant positive impact on FDI. We also find that restrictions in the manufacturing sector have restrictive impacts on inwrad FDI in big emerging countries, and those in the mining, quarrying, and oil extraction sector hinder inward FDI in African countries. Reforms to liberalize sectoral restrictions by country have positive effects on FDI, but deregulation of the services sector has beneficial effects on inward FDI in all countries.

Keywords : International Trade, FDI stocks, FDI restrictions, Gravity model.

JEL: D25, F10, F14, L51.

Acknow ledgements: I would like to thank Michel Dupuy, Jean-Marie Cardebat and Mehdi El Herradi for their insightful comments and participants at LAREFI weekly seminar for doctoral students (2019).

To cite this paper: ZONGO Amara (2021), The Effects of Restrictive Measures on Cross-Border Investment: Evidence from OECD and Emerging Countries, Bordeaux Economics Working Papers, BxWP2021-09

https://ideas.repec.org/p/grt/bdxewp/2021-09.html

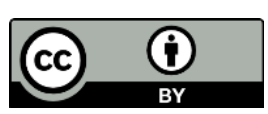




\section{INTRODUCTION}

Foreign direct investment (FDI) has become more and more important in economic growth and globalization in the last years. Indeed, FDI can increase productivity and change the comparative advantage of host countries. The establishment of multinational firms, capital accumulation, or delocalization can reduce unemployment, income inequality, poverty, improve technology transfer, and increase product variety through innovation (Hale and $\mathrm{Xu}$, 2016; Dritsaki and Stiakakis, 2014). The empirical literature suggests a positive correlation between FDI and economic growth (Iamsiraroj and Doucouliagos, 2015). However, several factors determine the massive inflow of FDI into a country and its effectiveness in economic growth (Alfaro et al., 2004; Li and Liu, 2005; Batten and Vo, 2009; Desbordes and Vicard, 2009). A strong macroeconomic framework with competitive and effective policies is necessary and contributes to attracting more FDI into a country (tax rates, restrictions on financial transactions, legal framework, economic and political stability, etc.). Indeed, an investment environment that considers the local institutions, regulations and policies in which companies operate stimulates economic growth by encouraging firms to invest. In this case, regulation has an impact on job creation and sustainability (World Bank, 2005). The positive link between FDI and growth is stronger in open economies with an educated workforce and developed financial markets (Bodman and Le, 2013). Moreover, some analyses have showed the positive link between FDI inflows and low economic policy uncertainty (Gulen and Ion, 2015).

Studies showing the relationship between FDI and regulation suggested that the FDI sector is far less liberalized than trade in goods and services (Ghosh et al., 2012). Although regional, bilateral, and multilateral trade and investment agreements have reduced formal barriers, restrictions are still significant in some countries and affect FDI. The regulatory framework plays a key role in FDI flows. Indeed, regulation has a profound and durable impact on a firm's financial choices and is seen as a crucial driver of investment. To encourage FDI, authorities must reduce the costs, minimize the risks associated with investment, and create an appropriate climate for the domestic economy. Regulation must be both optimal and competitive, protecting investors from potential risks, promoting competition among firms across borders, and protecting consumers from higher prices.

In 2018, inward FDI represented about $2 \%$ of GDP in the EU and 1.5\% of GDP in all OECD countries (see Figure 1). But we find that investments dropped by 3 to $1 \%$ of GDP between 2016 and 2018, which is contrary to the acceleration of GDP and trade growth. These trends are more significant in advanced countries than emerging countries (see Figures 2 and 3). In this year, some 55 economies introduced at least 112 measures affecting foreign investment. Two thirds of these measures sought to liberalise, promote and facilitate new investment (falling since 2016). Almost a third of these measures are new restrictions (increasing since 2016) (UNCTAD, 2019). How can we explain the decline in foreign investment? Is it a consequence of restrictive or sub-optimal policies? What is the real impact of restrictive measures on investment? Have restrictions on investment stimulated capital accumulation in the markets? 
Figure 1: Inward FDI flows, \% of GDP, 2010-2018

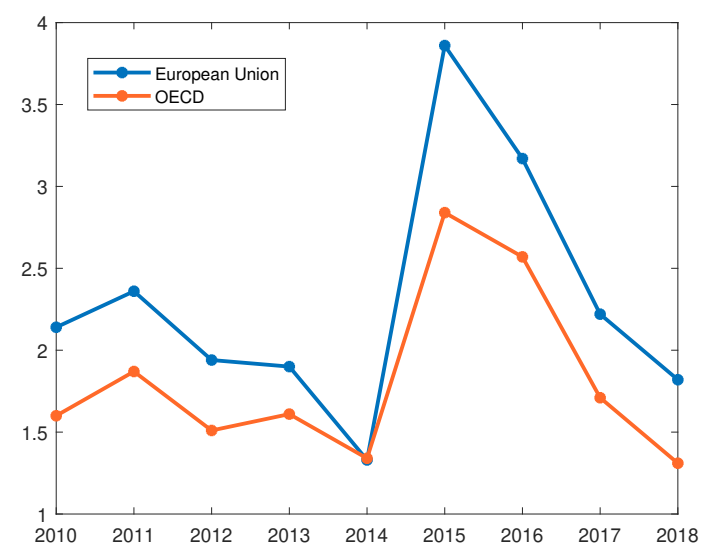

Source: OECD database

Figure 2: Inward FDI in advanced countries as \% of GDP, 2010-2018

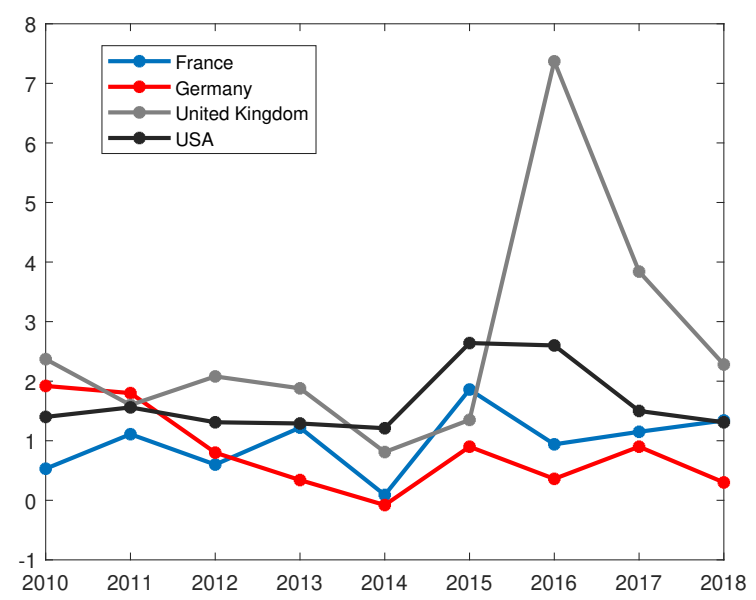

Source: OECD database
Figure 3: Inward FDI in emerging countries as \% of GDP 2010-2018

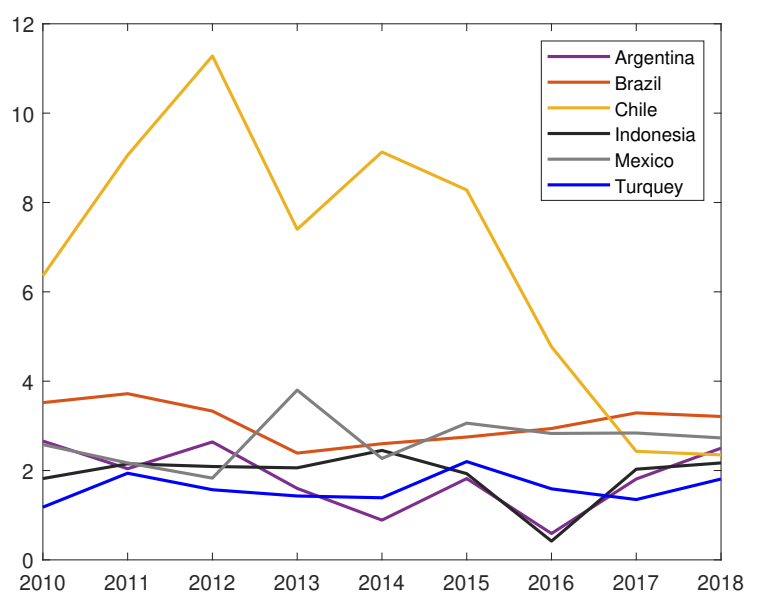

Source: OECD database

This paper examines the effects of global and sectoral restrictive measures on FDI among 49 advanced and emerging countries from 2010 to 2019. The existing empirical literature on the effects of restrictions on FDI has shown negative impacts of restrictive measures on FDI (Nicoletti et al., 2003; Ghosh et al., 2012). Some studies have underlined the restrictive effects of measures on cross-border M\&A in the secondary sector and non-financial services (Gregori and Nardo, 2021). Others have highlighted the negative effects of these measures on cross-border M\&A in the services sector (Mistura and Roulet, 2019). Mistura and Roulet (2019) investigate the impacts of restrictions on global inward FDI and cross-border M\&A across 60 advanced and emerging countries from 1997 to 2016, and Gregori and Nardo (2021) analyze the effects on EU member countries from 2011 to 2018. Few studies have empirically measured the impact of sectoral restrictive measures on overall inward FDI between advanced and emerging countries. 
Our paper contributes to the literature about the effects of restrictive measures on FDI in advanced and emerging countries. However, it is innovative in 3 aspects .

First, similar to Mistura and Roulet (2019), we estimate through an augmented gravity model the effects of restrictive measures on cross-border FDI in 49 developed and emerging countries from 2010 to 2019. We use the OECD FDI Regulatory Restrictiveness Index that captures barriers to FDI entry in 22 economic sectors across 69 countries. The index measures institutional factors that could influence FDI, such as restrictions on equity or key personnel for foreign investors, limitations on the establishment of branches, and clauses on profit and capital repatriation. Moreover Mistura and Roulet (2019) investigate the effects of restrictions on global FDI across advanced and emerging countries in 2001 to 2012 and on M\&A from 2001-2016. our paper provides a more recent analysis of the effects of restrictions on global FDI among advanced and emerging countries from 2010 to 2019. It considers the latest international guidelines for compiling foreign direct investment (FDI) statistics. ${ }^{1}$ Second, Mistura and Roulet (2019); Gregori and Nardo (2021) study the effects of different types of restrictive measures on FDI. Our model examines in more details the impact of global and sectoral restrictive measures on cross-border FDI. We consider FDI restrictions in the primary, secondary, and tertiary sectors, and further investigate the more disaggregated sectoral effects. The last contribution relates to the type of country considered. Contrary to Mistura and Roulet (2019), who analyze the effects of restrictions on FDI between OECD and non-OECD countries, we examine these effects at three levels: first, a study on FDI between advanced countries (intra-OECD), then among OECD countries and emerging countries (BRICS and some Latin American and Asian countries), and finally between OECD countries and middle-income countries (North African countries and South Africa). ${ }^{2}$ Indeed, depending on type of economy, the impacts of sectoral measures are different. OECD countries have a more service-oriented economy, emerging countries have a manufacturing and primary sector-based economy and the economy of African countries depends on agriculture and natural resources.

Our results suggest that overall restrictive measures have negative and non-significant effects on cross-border FDI across OECD countries, while restrictions in the service sector have negative and significant effects on FDI. Indeed, an increase of 0.05 points in FDI restrictions in this sector decreases inward FDI by about $17.36 \%$. Moreover, the overall restrictive measures and those in the service sector have negative and significant effects on inward FDI among OECD and emerging countries. An increase of 0.05 points is associated with a decrease in inward FDI respectively by $14.43 \%$ for global measures and $31.31 \%$ for those in services. In addition, restrictions in the services sector hamper bilateral FDI between OECD and African countries, the effects being more pronounced for African countries. Interestingly, restrictive measures in the secondary sector stimulate FDI between advanced and African countries. The effects are significantly negative for OECD countries, so we can conclude that restrictions in this sector boost inward FDI in African countries. The analysis of disaggregated sectoral restrictive measures shows that restrictions in business and other financial services are negatively associated with intra-OECD FDI and restrictive measures in the banking sector have a positive and significant impact on intra-OECD FDI. A rise of 0.05 points in restrictions in the banking sector is associated with an increase in inward FDI by $28.30 \%$ on average. The

\footnotetext{
${ }^{1}$ In 2014, many countries implemented the latest international guidelines for compiling foreign direct investment (FDI) statistics (OECD, 2015).

${ }^{2}$ The countries with FDI restrictive measures data available in our sample are North African countries and South Africa.
} 
restrictive measures in the manufacturing sector have restrictive impacts on inward FDI in big emerging countries, most pronounced in the BRICS countries, and those in the mining, quarrying, and oil extraction sector are barriers to inward FDI in African countries. Reforms to liberalize sectoral restrictions by country have positive effects on FDI, but deregulation of the services sector has beneficial effects on inward FDI in all countries.

The remainder of this paper is structured as follows. The next section documents recent literature on the effects of FDI regulation on investment. In the second part, we describe our econometric model with data, sources, and the type of regression used. The third section presents and discusses the results. The last section uses the results of this study to perform policy simulation.

\section{Literature ReVIEW}

Empirical studies that examine the impact of restrictive measures on FDI use two main indices. Some authors study the effects of restrictions on FDI using the FDI Regulatory Restrictiveness Index of OECD and others !the indexes of capital account restrictions based on IMF's AREAER database. $^{3}$

Authors such as Nicoletti et al (2003), based on the original version of the index created by Golub (2003) ${ }^{4}$ and the OECD's PMR ${ }^{5}$, explore the effects of FDI restrictions and other policies on foreign direct investment in a panel of 28 OECD countries between 1980 and 2000. The paper uses a gravity model to control bilateral outward FDI flows and a dynamic panel model to explain total multilateral inward FDI stocks. Their results suggest that FDI restrictions could reduce bilateral outward FDI stocks by between $10 \%$ and $80 \%$ on average, depending on the type of restriction. Inward FDI stocks are also impacted by FDI restrictions, but the results should be treated carefully due to the lack of variability of restrictions across OECD member countries. The analysis of Ghosh et al (2012) similar to the previous one shows the impact of restrictions on inward FDI stocks using panel data (1981-2004) for 23 OECD countries. Based on the updated of Koyama and Golub (2006) index and a gravity model, they find significant negative effects of restrictions on inward FDI stocks. To determine the short- and long-run effects of the restrictions, they use an autoregressive distributed lag model. Their results show that the short-run elasticity estimated was between 0.06 and -0.14 , and the long-run elasticity between -0.64 and -1.49 .

The analysis of Ahrend and Goujard (2012) indicates that FDI restrictions may contribute to greater risks of financial crisis. Indeed, higher restrictions in OECD countries, measured by OECD indexes, and anti-competitive product market regulation have contributed to reduced financial stability. That is due to a rise of countries' debt over FDI or capital investment. By contrast, more stringent capital regulations for banks and more openness to foreign bank entry have reduced the vulnerability to financial contagion. Fournier (2015) examines the determinants of foreign direct investment (FDI) from 1998 to 2013, including FDI restrictions. Using gravity models and the recent version of the OECD FDI restrictiveness index, he finds a

\footnotetext{
${ }^{3}$ Database on the exchange rates and trade regimes of all members of the International Monetary Fund (currently 189 countries) and three territories (Aruba, Hong Kong SAR, and Curaaso and Sint Maarten - formerly the Netherlands Antilles).

${ }^{4}$ The first to construct the aggregate index of FDI restrictions.

${ }^{5}$ Product Market Regulation index.
} 
significant negative impact of restrictions on FDI stocks after controlling for various political and structural determinants of bilateral FDI.

Recent studies examining the impacts of restrictive measures on FDI through the OECD FDI Regulatory Restrictiveness Index are those by Mistura and Roulet (2019) and Gregori and Nardo (2021). They differ from those mentioned above because they examine the effects of restrictions on aggregate FDI, sectoral FDI, and M\&A. They also examine the impact of different types of restrictions such as foreign equity limitations, screening or approval mechanisms, restrictions on the employment of foreigners as key personnel and operational restrictions. Mistura and Roulet (2019) find that reforms liberalising FDI restrictions by about 10 percent could increase bilateral FDI in stocks by 2.1 percent on average. The effects are greater for FDI in the services sector, but also in manufacturing sectors which are typically open to FDI. The effect of reducing foreign equity limitations is the strongest, and foreign investment screening policies significantly curb FDI, but to a much lower extent. Gregori and Nardo (2021) show that the presence of formal screening procedures does not negatively affect cross-border investment on average. Other restrictive policies, such as licensing requirements, quantitative limitations, restrictions to the market access and activity of foreign companies limit M\&A flows. This is particularly relevant in the manufacturing and non-financial services industries, where M\&A flows are negatively affected by restrictions on foreign personnel being employed in key positions, and restrictions on the establishment of branch offices, land acquisition, or profit and capital repatriations. Their results are also in line to the literature about the effects of regulation on trade in services. Indeed Van der Marel and Shepherd's (2013) examine the relationship between trade in services and regulation. They find a negative relationship between regulatory restrictiveness and trade flows, with the effects varying across sectors. Nordås and Rouzet (2017) confirm this result. In their gravity model relating trade in services with regulatory restrictions, tighter restrictions decrease both trade and investment, with the exports of services more impacted than imports.

Contrary to the above studies, Binici, Hutchison and Schindler (2009) apply an index of capital restrictions based on IMF's AREAER information, by asset class and covering 74 countries over the period 1995-2005. They study the effects of FDI and equity portfolio investment restrictions on total inward and outward FDI and equity portfolio investment. The results suggest that restrictions control capital outflows, not inflows. The study of Arbatli (2011) similar to the previous one, uses capital account restriction indices based on IMF's AREAER database. Through a binary index of FDI restrictions, he investigates the determinants of FDI flows into emerging economies. The author creates two binary indicators of FDI restrictions: one that assesses the existence of any restrictions on FDI inflows; and one that captures restrictions on the liquidation of direct investment. He uses a dynamic panel model approach to model FDI flows and data for 46 countries over 20 years. The results suggest that FDI capital restrictions have a significant negative effect on inward FDI, but no significant effect was found for restrictions on the liquidation of investment.

\section{Theoretical Gravity Model for FDI}

Gravity model, is increasingly used when investigating determinants of FDI flows. ${ }^{6}$ Head and Ries (2008) provide theoretical micro-foundations for a gravitational model of FDI and

${ }^{6}$ Wei (2000) or Bénassy-Quéré et al. (2007). 
motivate its application for modelling bilateral FDI as well as trade flows.

The framework used in this paper is based on recent advances in the literature on gravitational models (see Yotov et al., 2016). In particular, we apply the gravity modeling approach for FDI developed by Anderson et al $(2016,2017)$. Indeed, their model shows how trade and FDI are linked and how they respond to natural or man-made barriers to trade and investment.

In particular, Anderson et al $(2016,2017)$ model focuses on the interpretation of FDI based on technological capital or knowledge capital. A given stock of technological capital (patents, plans, management skills, etc.) can be used simultaneously in more than one country. The value of knowledge capital increases when it can be "leased" to other countries as FDI. Since knowledge capital flows are largely intangible and therefore difficult to measure, bilateral FDI stock will be used as a proxy indicator of knowledge capital flows between two countries.

FDI from country $\mathrm{i}$ to country $\mathrm{j}$ is as follows: $F D I_{i j}^{\text {stock }}$. It is positively influenced by the size of source country $\left(E_{i}\right)$, as large economies tend to invest more in technological capital. The stock of bilateral FDI is also positively influenced by the size of destination country $\left(Y_{j}\right)$, as large economies can in principle absorb more foreign technology. If the size of the aggregate stock of technological capital in country i is denoted by $M_{i}$, the ratio $\frac{Y_{i}}{M_{i}}$ can be considered as a gross measure of the potential absorptive capacity of country $j$ for FDI-related technological capital from country i. FDI flows are impeded by obstacles or frictions. For FDI, the relative openness of country $j$ to foreign technologies can be represented by $i j$, which has values from 0 to 1 . If $w_{i j}=1$, country $\mathrm{j}$ is fully open to the entry of technological capital from country $\mathrm{i}$, while in the case of $w_{i j}=0$, no technological capital from country $i$ is allowed. All these factors are the main determinants of the bilateral stock of FDI. ${ }^{7}$ The general formulation is as follows:

$$
F D I_{i j}^{\text {stock }}=w_{i j}^{\eta} \frac{\alpha E_{i}}{P_{i}} \frac{Y_{i}}{M_{j}}
$$

Wth $E_{i}$ measures the size of country $i$ as a total expenditure, including expenditures for the development of technological capital; $Y_{j}$ is a measure of the size of host country $\mathrm{j}$. The parameter $\eta$ is the elasticity of FDI revenue flows with respect to the measure of openness. More openness in country $\mathrm{j}$ will lead to more frequent use of the technology stock, which will lead to an increase of FDI revenues. The other elements of equation (1) come from the structural gravity system for trade, in which the FDI determinants are integrated. $\alpha$ groups a set of fixed parameters from the theoretical model. ${ }^{8}$ Finally, $P_{i}$ is the inward multilateral resistance term of the gravity trade model. They aggregate the bilateral trade costs of country i with all other countries:

$$
P_{i}=\left[\sum_{j=1}^{N}\left(\frac{t_{j i}}{\Pi_{j}}\right)^{1-\sigma} \frac{Y_{j}}{Y}\right]^{\frac{1}{1-\sigma}}
$$

With $t_{j i}$ represents the bilateral trade-cost frictions (bilateral distance, having different languages, common border..) that increase bilateral trade cost. $Y=\sum Y_{j}$ is world production or world GDP, used to normalize the size of destination country $\left(Y_{j}\right)$, and $\sigma$ is the elasticity of substitution from CES functions used to aggregate multilateral resistance (MR) terms. ${ }^{9}$

\footnotetext{
${ }^{7}$ Time indices are omitted in this representation.

${ }^{8}$ These include parameters such as the depreciation rate, the utility function discount factor and other parameters that are used in the underlying theoretical model (see Anderson et al., 2016, 2017).

${ }^{9}$ With $\sigma>1$, the elasticity of substitution shows that all countries have a preference for a variety of products and technological capital by origin country.
} 
World trade is a fully integrated system, equation (2) also contains the term $\Pi_{j}$, which represents the outward multilateral trade resistances of country $\mathrm{j}$. It aggregates the bilateral trade costs of country $j$ with respect to all other countries. The gravity system of the FDI becomes:

$$
\Pi_{j}=\left[\sum_{j=1}^{N}\left(\frac{t_{j i}}{\mathbb{M}_{i}}\right)^{1-\sigma} \frac{E_{i}}{Y}\right]^{\frac{1}{1-\sigma}}
$$

Equation (3) shows that if trade costs increase in host country $j$, domestic prices rise and thus reduce the country's real potential to absorb foreign technological capital.

The author has highlighted the gravity estimation of bilateral FDI remains Bénassy-Quéré et al. (2005). The latter study the impacts of FDI determinants on horizontal FDI. In the model, bilateral FDI stocks depend on both economies' GDP, the determinants of supply and demand, and the distance between capital. However, recent theoretical developments have provided other foundations for the application of a gravity model to other FDI models (Kleinert and Toubal, 2010; Bergstrand and Egger, 2007; Head and Ries, 2008; De Sousa et al., 2012; Heid and Larch, 2016 and Nordås and Rouzet, 2017). ${ }^{10}$ Bergstrand and Egger (2007) implement a gravity model of FDI by including several aspects of FDI (foreign direct investment (FDI), foreign affiliate sales (FAS) and multinational companies (MNEs). However, Head and Ries (2008) develop a gravity model of FDI by considering the M\&A process, in which the holding company tries to control the assets abroad.

\section{Model And Estimation Issues}

In our empirical analysis, we examine the impacts of restrictions on FDI stocks between OECD and emerging countries. Using the model of Anderson and Van Wincoop (2003); Anderson et al $(2016,2017)$, our baseline regression equation is the following:

$$
\begin{array}{r}
F D I_{i j, t}=\exp \left[\beta_{0}+\beta_{1} \operatorname{Ln}\left(F D I_{i j, t-1}\right)+\beta_{2} F D I R I_{j, t-1}^{s}+\beta_{3} t_{i j, t-1}+\right. \\
\left.\beta_{4} \operatorname{Ln}\left(G D P_{i, t-1}\right)+\beta_{5} \operatorname{Ln}\left(G D P_{j, t-1}\right)+\beta_{6} X_{j, t-1}+\alpha_{i}+\phi_{j}+\gamma_{t}+\epsilon_{i j, t}\right]
\end{array}
$$

With $F D I_{i j, t}$ represents FDI stocks from country i (the reporting or source country) to country $\mathrm{j}$ (the partner or host country) in period $\mathrm{t}(2010-2019)=\frac{F D I_{i, j}}{\left.G D P_{\text {deflator }(i, t)}\right)}$. FDI are calculated by dividing FDI stocks (in U.S. dollars) by the average of the source and host country GDP deflators to remove inflation. $F D I_{i j, t-1}$ is one-year lagged dependent variable (Egger and Merlo, 2007). ${ }^{11}$ Following Mistura and Roulet (2019), all explanatory variables are lagged by one year to reduce potential endogeneity issues. FDI $R I_{j, t-1}^{s}$ is our interest variable (FDI Regulatory Index), i.e. the restrictive measures on FDI implemented in the destination country $\mathrm{j}$ at the time $\mathrm{t}-1$ in the sector $\mathrm{s}$ ( $\mathrm{s}=$ primary, secondary and tertiary sectors). It is measured by the OECD FDI restrictiveness index. $t_{i j, t-1}$ includes time-invariant bilateral control variables, i.e. bilateral distance, common language, common border, colonial links

\footnotetext{
${ }^{10}$ The studies combine both horizontal and vertical FDI.

${ }^{11}$ They argue that ignoring the dynamic nature of FDI could lead to an overestimation of the effect of bilateral factors.
} 
(Blonigen and Piger, 2014) $)^{12}$ and time varying variables such as regional trade agreements (RTA), bilateral investment treaties (BIT) and human capital dissimilarity $\left(H C D_{i j, t}\right)$. According to Ethier and Markusen (1996), the difference in factor endowments can affect inward FDI. ${ }^{13}$ We include standard gravity variables, specifically the GDP of both the origin country and the destination country. $X_{j t}$ covers destination country specific characteristics such as regulatory quality (Bénassy-Quéré et al., 2007) and FDI determinants in destination country such as trade openess ${ }^{14}$, productivity, labour freedom index ${ }^{15}$, tax burden (Djankov, Ganser, McLiesh, Ramalho, and Shleifer, 2010). ${ }^{16} \alpha_{i}$ and $\phi_{j}$ represent source-host country fixed effect (dummy variables that control the inward and outward multilateral resistance terms). $\gamma_{t}$ is a time fixed effect (capturing the global macroeconomic cycle) and $\epsilon_{i j t}$ is a error term. Standard errors are clustered by country pairs to control for potential heteroskedasticity and to limit the potential effect of persistence over time of FDI stock levels in each pair of countries, see Fournier (2015). $\beta_{2}$ is the coefficient of interest; according to the litterature it is negative (Ghosh et al., 2012; Fournier, 2015; Mistura and Roulet, 2019).

Our dependent variable takes a value of zero and an estimation using OLS leads to a bias (zero FDI is associated with high bilateral fixed costs). To avoid biased estimation results, we use the Pseudo-Maximum Likelihood estimator (PPML) suggested by Santos Silva and Tenreyro (2006). The PPML is used in our case in order to deal with the constraints of zero trade between States, and also estimates the non-linear shape of the gravity model in the presence of heteroskedasticity. However, an important assumption of the PPML estimator is equidispersion, which means that the conditional variance of the dependent variable and its conditional mean are equal. PPML estimation can be assessed by solving the following condition:

$$
\sum_{p}\left[X^{p}-\exp \left(Z^{p} \beta\right)\right]=0
$$

Where $p$ is the country pair, $X^{p}$ is unilateral trade (i.e. exports or imports) between country pairs in non-logarithmic levels and $Z^{p}$ is the complete vector of the gravity equation as defined above.

We include in the estimation fixed effects by origin country to control for unobservable multilateral resistance terms (Olivero and Yotov, 2012). ${ }^{17}$

\section{Data Description}

To analyse the effects of restrictive measures on FDI stocks between OECD and emerging countries, we use panel data across 49 countries from 2010 to 2019. Indeed, we consider OECD

\footnotetext{
${ }^{12}$ They identify as main enabling factors for inward FDI the traditional gravity variables such as cultural distance, difference in labor endowment, and the presence of trade agreements.

${ }^{13}$ Golub et al., 2003 define human capital dissimilarity as the difference in absolute value between the human capital index in the destination country and that in the source country $H C D_{i j, t}=\mid\left(\ln \left(\right.\right.$ education $_{j t}-\ln \left(\right.$ education $\left._{i t}\right) \mid$.

${ }^{14}$ Chakrabarti (2001) finds that a country's degree of openness to international trade is a relevant determinant of the FDI decision, because most investment projects concern the tradable sector.

${ }^{15}$ Nordin et al. (2019).

${ }^{16}$ They estimate, using cross-sectional survey data for 85 developed and developing countries, that corporate taxes always have a negative and significant effect on FDI inflows.

${ }^{17}$ We also estimated the model using destination country's dummies, but the model presents convergence issues (Santos Silva and Tenreyro, 2011).
} 
countries because inward and outward FDI account for a large share of GDP and we include emerging countries due to the high level of restrictions in FDI (see figure 4). Annual data from 2010-2019 to explain the decline in inward FDI since 2016, and to consider the new FDI statistics introduced in 2014. Our dependant variable is aggregate bilateral FDI stock. The data are collected on OECD Foreign Direct Investment Statistics. ${ }^{18}$ The data cover a range of advanced and emerging countries in terms of origin and destination. However, we use the latest version set up by the OECD. ${ }^{19}$ This database highlights bilateral FDI between OECD member and non-member countries and runs from 2005 to 2019. It also highlights sectoral FDI (primary, manufacturing and service sectors). ${ }^{20}$ Missing data (or non-reported, suppressed) and negative FDI are replaced by 0 in our case, because negative values are interpreted as disinvestment and to have a balanced panel (Kox and Rojas, 2019).

Figure 4: Correlation between FDI and restrictive meausres, 2019

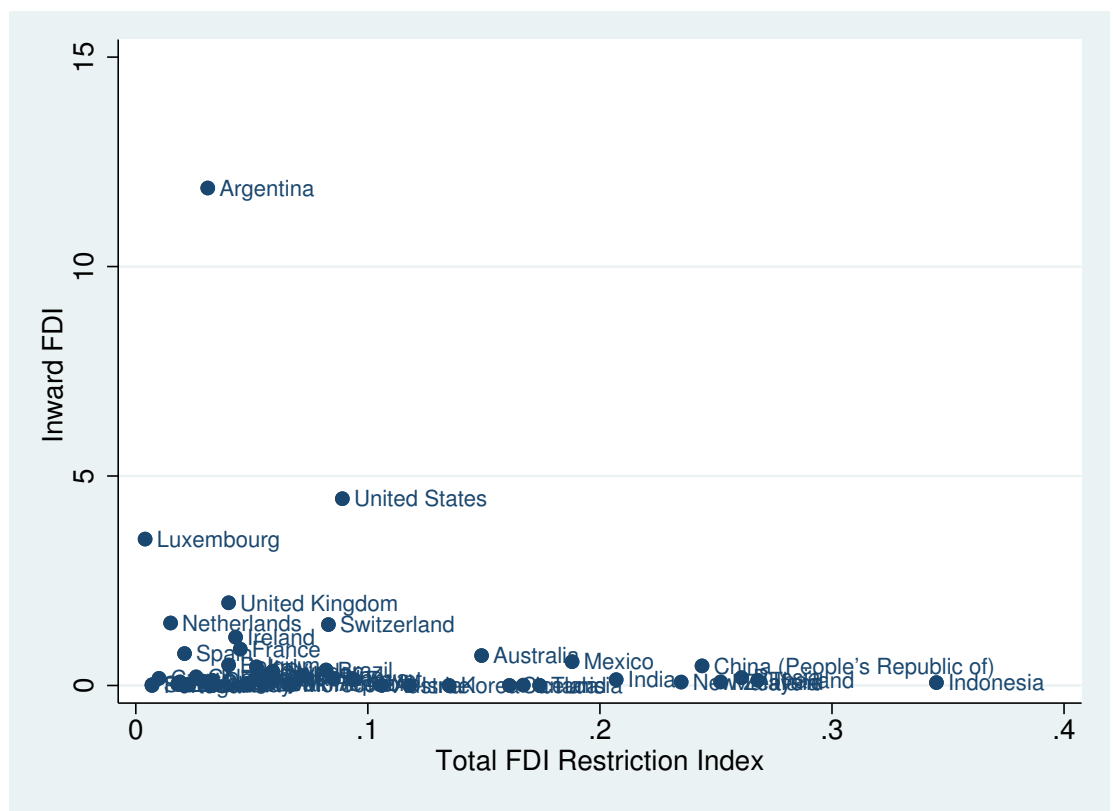

Source: OECD database

Our interest variable captures the level of restrictiveness in FDI. We use FDI Regulatory Restrictiveness Index of OECD. Indeed, this variable measures the restrictiveness of the policies implemented in the FDI sector in 70 countries (36 OECD countries and 34 non-OECD countries). It gauges the restrictiveness of a country's FDI rules by looking at the four main types of restrictions on FDI:

- Foreign equity limitations.

- Screening or approval mechanisms.

- Restrictions on the employment of foreigners as key personnel.

- Operational restrictions, e.g. restrictions on branching and on capital repatriation or on land ownership.

\footnotetext{
18 https://stats . oecd.org/Index . aspx?QueryId=64194.

${ }^{19}$ Benchmark Definition 4th Edition (BMD4).

${ }^{20}$ Sector-specific FDI data are not bilateral so the sectoral analysis will be conducted with the sectoral FDI restriction index.
} 
The restrictions are also quantified in three sectors of activity: primary, secondary and tertiary. Restrictions are evaluated on a 0 (open) to 1 (closed) scale. Data are available for 1997, 2003 and 2006 and uninterrupted annual data for the period 2010-2019. Data collected from OECD FDI Regulatory Restrictiveness Index database.

In addition, bilateral resistance variables such as the bilateral distance between the two capitals and binary variables (common border, language and colonial links) come from CEPII (Centre d' Etudes Prospectives et d' Informations Internationales) database. Binary variables such as regional trade agreements are obtained from the WTO (Regional Trade Agreements Information System, RTA-IS) and information on the signing and ratification of bilateral investment treaties is taken from on UNCTAD's International Investment Agreements database.

We consider the specific characteristics of the destination country that affect inward FDI such as regulatory quality (data available on Worldwide Governance Indicators). It refers to perceptions of the ability of the government to formulate and implement sound policies and regulations that permit and promote private sector development. The indicator is estimated yearly at the country level, in units of a standard normal distribution, ranging from approximately -2.5 to 2.5 .

FDI determinants in destination countries such as tax burden and labour freedom index are collected on The Heritage Foundation database. ${ }^{21}$ Tax burden is a composite measure that reflects marginal tax rates on both personal and corporate income and the overall level of taxation (including direct and indirect taxes) imposed by all levels of government as a percentage of gross domestic product (GDP). The labor freedom component is a quantitative measure that considers various aspects of the legal and regulatory framework of a country's labor market, including regulations concerning minimum wages, laws inhibiting layofs, severance requirements, and measurable regulatory restraints on hiring and hours worked, plus the labor force participation rate as an indicative measure of employment opportunities in the labor market. These two indices are graded on a scale of 0 (less flexible) to 100 (more open or flexible). Productivity are collected on OECD database. ${ }^{22}$ Human capital index in Penn World Table database of Groningen Growth and Development Centre. ${ }^{23}$ Trade openness, GDP of exporting and importing countries are extracted from the World Bank database (World Development Indicators)

\section{FDI Gravity Results and Discussion}

This section presents and analyzes the empirical results. We estimate the effects of restrictive measures on FDI stocks between OECD and emerging countries from 2010 to 2019. Tables 2, 3 and 4 present the baseline gravity model results for cross-border FDI using the OECD FDI restrictiveness index. Table 2 presents the results of restrictions on bilateral FDI among advanced countries (intra-OECD) and tables 3 and 4 respectively the results on cross-border FDI among advanced and big emerging countries and between OECD and middle-income

\footnotetext{
${ }^{21}$ https : //www.heritage.org/index.

${ }^{22}$ It measured by GDP per hour worked (U.S dollars).

${ }^{23}$ This index refers to the number of years of schooling and return on education.
} 
emerging countries (African). ${ }^{24}$ In order to determine whether the effects of FDI restrictions can be expected to differ for developed and developing economies, we include a dummy variable equals 1 if the destination country is an OECD member in year $t$ and an interaction term with the variable of interest capturing their level of FDI restrictiveness (results presented in Tables 3 and 4). We confirmed the validity of our results using a series of robustness tests presented in Tables 5 to 11. We apply the PPML estimator to control for the zero FDI and heteroskedasticity issues, we also include country fixed effects to control for structural multilateral resistance. Therefore, in order to better capture multilateral resistance and produce unbiased estimates, we include country and time fixed effects separately.

\section{i. Baseline results}

In terms of variables of main interest - the FDI restrictiveness indices - we find that global FDI restrictions have a negative and non-significant effect on intra-OECD FDI because the sectoral FDI regulation index is larger than the global index (see Figure 5). Moreover, these restrictions represent a barrier to cross-border FDI among OECD countries and the big emerging countries. The introduction of reforms leading to a 0.05 point reduction in level of FDI restrictiveness could increase bilateral FDI inward stocks by around $17.17 \%$ on average (column 4 of Table 3). ${ }^{25}$ The interaction between our dummy variable and the restrictive measures does not have a significant effect on FDI. The combined negative and significant effect of global restrictive measures and non-significant effect of our interaction term suggests that the negative effects of restrictions on FDI tend to be more accentuated for emerging economies. ${ }^{26}$ This result confirms the findings of Mistura and Roulet (2019). Further, global restrictive measures do not affect cross-border FDI between OECD and African countries (Table 4). ${ }^{27}$

The sectoral analysis of FDI restrictive measures shows significant negative effects of restrictions in the services sector on intra-OECD FDI. The effect of a 0.05 point reduction in FDI restrictions in services is associated with a $17.36 \%$ increase in global FDI (column 4 of table 2). The reason is that services are the largest sector for inward investment in the OECD and also the most restrictive compared to other sectors, which explains the non-significant results (see Table 1 and figure 5). Indeed, the manufacturing sector, excluding defense and military goods, is the most open sector where countries generally allow foreign investment. In the primary sector, the location-specific and licensing-heavy nature of some of such investments (e.g., extractive industries) may offer relatively few alternatives for foreign investors. The existence of numerous taxes and royalties where economic rents are potentially high, as in the extractive industries, to capture a part of such rents for their nationals limits investment in this sector (Mistura and Roulet, 2019). The analysis on FDI across advanced and large emerging countries suggests significant negative effects of restrictive measures in the services sector. A reduction in service sector restrictions by 0.05 points leads to an increase in global inward FDI by $31.31 \%$ on average, and these effects are greater for emerging countries.

Insert Table 1 here.

\footnotetext{
${ }^{24}$ The estimated coefficients from regressions pooling wealthy and poor economies may fail to capture the true relationship between FDI and the explanatory variable of interest (Blonigen and Wang's, 2004).

${ }^{25}$ The percentage change in inward FDI from a 0.05 point reduction in the FDI restrictiveness index is calculated as follows: [exp(-0.05*coefficient) -1$]^{*} 100$.

${ }^{26}$ The reason is that global and sectoral restrictions, especially in services, are very high in emerging countries.

${ }^{27}$ We have a limited sample of African countries, which could explain these results.
} 
Figure 5: OECD and Emerging countries FDI Regulatory Restrictiveness Index in 2019

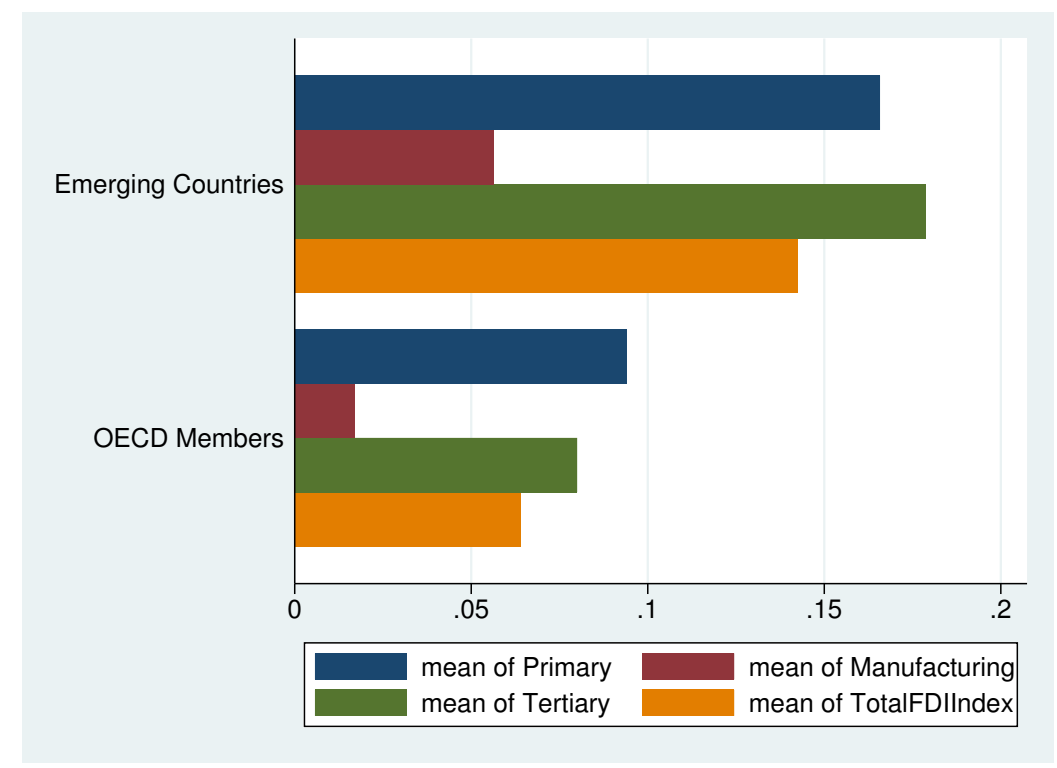

Source: OECD FDI Regulatory Restrictiveness Index databasee

Moreover, restrictions in the services sector hamper bilateral FDI between OECD and African countries, and as before the effects are more pronounced for African countries (column 8 of table 4). Interestingly, restrictive measures in the secondary sector boost FDI between OECD and African countries. Our interaction term shows significant negative effects of these measures for OECD countries and the combined effects show significant positive effects of restrictions in the manufacturing sector for African countries. The negative effects of restrictive measures in the secondary sector on FDI between OECD countries refers to the existing literature on the effects of restrictions in services on the performance of manufacturing firms (Ariu et al., 2019; Ariu et al., 2020; Amara, 2021). Indeed, restrictions on FDI in services impact the productivity of manufacturing firms (increased costs of sourcing services) as they increasingly use services as an important input of manufacturing value added. The positive effect of restrictions in the manufacturing sector for African countries can be explained by the fact that the index in this sector measures FDI restrictions in the food, chemical, metal, and electronics industries. Contrary to OECD countries where these sectors are developed with more competition, they are still nascent in North and South Africa with lower competition. An increase in restrictions in this sector leads to an increase in economic rents from FDI (Rouzet and Spinelli, 2016). One of our robustness tests incorporates restrictions in the mining and natural resources sector (a developed industry in Africa), and we find negative effects on FDI in Africa.

The negative impacts of restrictive measures in FDI are due to high entry costs in the different sectors. In addition to acting as a barrier to entry, this result may also underscore a potential signaling effect of restrictions about the difficulties in doing business as a foreign investor, including outside of the restricted sectors. Services are the sectors that receive the most FDI and thus are the most affected by these restrictions.

Insert Table 2 here. 
Insert Table 3 here.

Insert Table 4 here.

In the different specifications, we also find the following effects: the standard gravity model variables such as distance, common language and colonial links have the expected signs and magnitudes and are statistically significant. Indeed, distance has negative and significant effects on cross-border FDI inflows among advanced and emerging countries as in the theory (Bénassy-Quéré et al., 2005; Basile et al., 2008). Binary variables such as common language and colonial links have positive and more significant effects on FDI between OECD and emerging countries. Moreover, the common border has negative and significant impacts on FDI inflows, which is contrary to the theory. This negative and significant sign is due to the substitutability between trade and FDI, especially between countries that share the same border (Gregori and Nardo, 2021). This can be explained by the European Monetary Union (Brouwer et al., 2008, Martínez-San Román et al., 2016) and the single currency (Camarero et al., 2018; Alfieri, 2020). Regional trade agreements (RTA) have significant negative effects on FDI in advanced countries, while there are significant positive impacts on cross-border FDI among advanced and emerging countries. The negative effect of trade agreements suggests that being a partner in a trade agreement tends to discourage FDI between origin and destination countries, because a trade agreement facilitates access to the destination country's market through other channels, such as exports or greenfield investments (Mistura and Roulet, 2019). Bilateral investment treaties (BIT) have negative and significant effects on cross-border FDI, more meaningful effects on FDI across OECD and emerging countries. The BIT has different characteristics than the RTA, it protects the investor against risks in the market receiving the FDI. It therefore establishes transparency on the host country (Bergstrand and Egger, 2013). These agreements among advanced countries and emerging or developing countries (North-South investment) have much greater effects than North-North agreements (Kox and Rojas, 2019). BITs affect negatively FDI inflows when the political risk in a country is high whereas the opposite occurs when the risk level is low (Tobin and Rose-Ackerman, 2005). ${ }^{28}$

If we consider the determinants and explanatory factors of FDI, the regulatory quality variable is positively related to cross-border FDI, highlighting the proactive role that public administration can exert to stimulate foreign investment (Gregori and Nardo, 2021). Trade openness attracts investment because of a complementarity between FDI and trade (Belke and Clemens, 2018). The dynamism of the destination economy has positive and significant impacts on FDI. These results confirm that the size of the destination country's market boosts cross-border investments by creating additional market shares, economies of scale, or reducing production costs for foreign investors (Eicher et al., 2012). Likewise, the dynamism of investing country is positively related to cross-border flows (Gregori and Nardo, 2021). The productivity measured by the GDP per hour employed is positively associated with FDI. Like the GDP of the destination country, productivity in the destination economy creates economies of scale and reduces production costs, which attracts cross-border FDI. The difference in relative human capital endowment is significant with a negative impact ${ }^{29}$, suggesting possibly the

\footnotetext{
${ }^{28}$ This confirms the negative and more significant effects on cross-border FDI among advanced and emerging countries (where the political risk is higher).

${ }^{29}$ The effect is more significant on FDI among advanced and emerging countries.
} 
predominance of horizontal FDI and M\&A investments (Mistura and Roulet, 2019). As Gregori and Nardo, 2021, the tax indicator does not have a significant effect on FDI flows, explained by the predominance of market factors over institutional aspects in driving cross-border investments (Gherghina, Simionescu and Hudea, 2019). Labour market flexibility attracts cross-border FDI. Indeed, labor market standards and regulations or any limitation placed on employment lead to labor market rigidity, which imposes costs on firms (Nordin et al., 2019). ${ }^{30}$

\section{ii. Robustness check}

In this section, we performed several robustness tests to confirm our baseline results. First, we split our sample in two periods (2010-2014) and (2015-2019) and examine the different effects of restrictive measures on FDI between advanced and emerging countries. This test highlights two trends: the effects of the policy on international guidelines for the compilation of foreign direct investment (FDI) statistics implemented in many countries in 2014 and the impacts of the 2008-2009 financial crisis that led to a stagnation of FDI. ${ }^{31}$ We consider the different trends between 2010-2014 (effect of the crisis) and 2015-2019 (effect of the new policy for the compilation of FDI statistics). The results are presented in Table 5 and show more significant effects in the period 2015 to 2019 and confirm our results found above; however, during this period, global restrictions have negative and significant effects on intra-OECD FDI and on FDI between OECD countries and large emerging economies. Restrictive measures in the post-crisis period had a greater impact on FDI between OECD countries and emerging markets.

Insert Table 5 here.

The second test examines the effects of restrictive measures on FDI between advanced and BRICS countries ${ }^{32}$ considered as large emerging countries and between OECD and emerging countries excluding BRICS. This test shows whether the effects are different among emerging countries. The results reported in table 6 show that restrictions have negative and more significant impacts on BRICS than other emerging countries and confirm that restrictions in the service sector have a significantly negative impact on cross-border FDI.

Insert Table 6 here.

OECD inward and outward FDI in the services sector is the largest in comparison to the other two sectors (accounts for almost $60 \%$ of total FDI, see table 1 ) and considering table 7 , FDI in the financial sector is the biggest of the cross-border FDI in services. The third test looks at the effects of restrictions in the disaggregated financial services sector on intra-OECD FDI. Table 8 presents the results and shows that restrictions in business and other financial services are negatively associated with cross-border FDI (negative and significant results). However, FDI restrictions in the insurance sector have no significant effect and those in the

\footnotetext{
${ }^{30}$ Their study argues that the growth-effect of FDI is possibly influenced by the flexibility of the labor market in the host country.

${ }^{31}$ Gregori and Nardo (2021) observed a stagnation of inward M\&As in EU countries during 2011-14.

${ }^{32}$ Brazil, Russia, India, China and South Africa.
} 
banking sector have a positive and significant impact on intra-OECD FDI, explained by the profit margin of FDI in this sector as a result of restrictions (Rouzet and Spinelli, 2016). ${ }^{33} \mathrm{~A}$ rise of 0.05 points in restrictions in the banking sector is associated with an increase in inward FDI by $28.30 \%$ on average.

Insert Table 8 here.

The two tests below estimate the effects of restrictive measures on FDI between OECD and emerging countries by type of economy. The big emerging countries have economies more oriented to the manufacturing and agricultural sectors than the North and South African countries where the main economic activity is agriculture and natural resources (table 9). In the first part, we study the effects of restrictions in the agricultural and manufacturing sectors on FDI between OECD countries and large emerging economies (results reported in table 10) and the second the effects of restrictions in the agricultural and natural resources sectors (mining, oil and gas, etc.) on FDI among OECD and African countries (table 11).

Insert Table 10 here.

Insert Table 11 here.

The results suggest that FDI restrictions in the manufacturing sector have significant negative effects on FDI between advanced and emerging countries, the effect being more pronounced if the destination country is an emerging country. In addition, restrictive measures in the mining, quarrying, and oil extraction sector have significant negative effects on FDI between advanced and African countries, with higher effects for African countries.

The last test examines the effects of restrictive measures on FDI across advanced and all emerging economies including Africa. North and South African countries are considered upper-middle-income countries according to the World Bank classification. The results presented in table 12 show significant negative impacts on FDI restrictions in the services sector. In addition, measures in the secondary sector are positively associated with inward FDI (significant but low magnitude). The positive impact is mainly due to restrictions in the secondary sector of African countries, as highlighted in our baseline results.

Insert Table 12 here.

These results underscore the implementation by the governments of attractive sectoral regulation of FDI. The effects of FDI vary according to the type of economy, but unanimously, liberalization of the services sector has more beneficial effects on inward FDI in all countries in order to boost the performance of manufacturing industries. The big emerging countries in addition to the services sector should deregulate the manufacturing sector which plays a vital role in economic activity, and for African countries, reforms to liberalize the natural resources sector would further boost inward investment. Governments also need to regulate FDI taking into account the restrictions of other countries, because regulations will affect FDI differently depending on the destination country.

\footnotetext{
${ }^{33}$ They showed that a high level of restrictiveness in the banking sector is associated with less competition in the market, so that incumbent financial institutions raise interest rates to increase their profit margins.
} 


\section{CONCLUSION}

This paper, which investigates the effects of restrictive measures on FDI, contributes to the literature on the impact of restrictions on FDI, but differs from recent studies because it examines the sectoral effects of FDI restrictions on cross-border FDI between advanced and emerging countries.

Using a gravity model we examined the effects of global and sectoral restrictive measures on FDI among OECD countries, between advanced and large emerging countries and finally between advanced and African countries from 2010 to 2019. Our results suggested that global restrictive measures have non-significant negative effects on cross-border FDI between OECD countries, while restrictions on FDI in the services sector are negatively associated with inward FDI. In addition, both overall and service sector restrictions have negative and significant effects on inward FDI among OECD and emerging market countries. In addition, restrictions in the services sector hamper bilateral FDI between OECD and African countries, the effects being more pronounced for African countries. Interestingly, restrictive measures in the manufacturing sector stimulate FDI between advanced and African countries. The effects are significantly negative for OECD countries, so we can conclude that restrictions in this sector stimulate inward FDI in African countries.

The results are robust to the baseline results. Several tests are performed. First, we estimated the effects of global and sectoral restrictions between advanced and emerging countries in the period 2010 to 2014 and 2015 to 2019. The results confirmed our baseline results and showed more significant effects in the period 2015 to 2019. The second test examined the impacts of restrictive measures on the BRICS and on emerging countries excluding the BRICS, the results are more significant on the BRICS than on other emerging countries. The third test evaluated the effects of disaggregated restrictions on intra-OECD FDI, especially in financial services. The results suggested that restrictions in business and other financial services are negatively associated with cross-border FDI. However, restrictions on FDI in the insurance sector have no significant effect and those in the banking sector have a positive and significant impact on intra-OECD FDI. The last two tests showed that restrictive measures in the manufacturing sector have restrictive impacts on inward FDI in emerging economies, particularly in the BRICS, and that restrictions in the mining, quarrying, and oil extraction sector are an obstacle to inward FDI in African countries.

We could improve our study by considering financial FDI such as M\&A. However, there are some important limitations, mainly related to the data. First, FDI restrictions have some limitations, notably that they are time-invariant for some sectors. Second, it would be really interesting to also examine the effects of these restrictive measures on domestic investment in future research.

This paper highlighted the detrimental impact of restrictive measures on cross-border FDI. It showed the negative impacts of sectoral restrictions depending on the type of economy receiving the FDI. From this study, we conclude that the drop of inward FDI in OECD countries since 2016 is due to a rise of restrictive and protectionist policies in order to protect local firms. It is also the result of Donald Trump's tax cuts since 2017. This measure led to repatriation of profits into United States. This decrease is probably due to the trade war between China and United States, which has a considerable effect on production and investment in global value chains. 


\section{REFERENCES}

[1] Ahrend, R. and Goujard, A. 2012. "International Capital Mobility and Financial Fragility: Part 3. How do Structural Policies Affect Financial Crisis Risk? Evidence from Past Crises Across OECD and Emerging Economies". OECD Economics Department Working Papers No. 966, OECD Publishing: Paris.

[2] Alfaro, Laura; Chanda, Areendam; Kalemli-Ozcan, Sebnem and Sayek, Selin. 2004. "FDI and economic growth: the role of local financial markets". Journal of International Economics, vol. 64(1), pages 89-112.

[3] Alfieri, L. 2020. "Heterogeneity of financial institutions in the process of economic and monetary integration in East Asia". The World Economy, Forthcoming.

[4] Arbatli, E. 2011. "Economic policies and FDI inflows to emerging market economies". IMF Working Paper No. 192.

[5] Anderson, J. E. and Van Wincoop, E. 2003. "Gravity with gravitas: A solution to the border puzzle". The American Economic Review., 93[1], 170-192.

[6] Anderson, J. E., M. Larch, and Y. V. Yotov. 2017. "Trade and Investment in the Global Economy". NBER Working Paper 23757, National Bureau of Economic Research.

[7] Arbatli, E. 2011. "Economic policies and FDI inflows to emerging market economies". IMF Working Paper No. 192.

[8] Ariu, Andrea; Breinlich, Holger; Corcos, Gregory and Mion, Giordano. 2019. "The interconnections between services and goods trade at the firm-level". Journal of International Economics, Elsevier, vol. 116(C), pages 173-188.

[9] Ariu, Andrea; Mayneris, Florian; Parenti, Mathieu. 2020. "One way to the top: How services boost the demand for goods". Journal of International Economics, Elsevier, vol. $123(\mathrm{C})$.

[10] Basile, R., Castellani, D. and Zanfei, A. 2008. "Location choices of multinational firms in Europe: The role of EU cohesion policy". Journal of International Economics, 74, 328-340.

[11] Belke, A. H. and Clemens, D. 2018. "Trade and capital flows - Substitutes or complements? An empirical investigation". (Ruhr Economic Papers, No. 776). ISBN 978-3-86788904-9. RWI - Leibniz-Institut fūr Wirtschaftsforschung.

[12] Bénassy-Quéré, Agnes; Fontagne, Lionel and Lahreche-Revil, Amina. 2005. "How Does FDI React to Corporate Taxation?". International Tax and Public Finance, Vol. 12, No. 5, 2005.

[13] Bénassy-Quéré, Agnes; Coupet, Maylis and Mayer, Thierry. 2007. "Institutional Determinants of Foreign Direct Investment". World Economy, Vol. 30, No. 5, pp. 764-782.

[14] Bergstrand, J. and Egger, P. 2007. "A Knowledge-and-Physical-Capital Model of International Trade Flows, Foreign Direct Investment, and Multinational Enterprises". Journal of International Economics, 73, 278-308.

[15] Bergstrand, J. and P. Egger. 2013. "What Determines BITs?". Journal of International Economics, 90(1): 107-122.

[16] Binici, M., Hutchison, M. and Schindler, M. 2009. "Controlling capital? Legal restrictions and the asset composition of international financial flows", IMF Working Paper No. 208. 
[17] Blonigen, B. A. 2005. "A review of the empirical literature on FDI determinants." Atlantic Economic Journal, 33(4), 383-403.

[18] Blonigen, B. A and Piger, J. 2014. "Determinants of foreign direct investment." Canadian Journal of Economics, 47(3), 775- 812.

[19] Bodman, P and Le, T. 2013. "Assessing the roles that absorptive capacity and economic distance play in the foreign direct investment-productivity growth nexus". Applied Economics, 45(8), 1027-1039, DOI: 10.1080/00036846.2011.613789.

[20] Brouwer, J., Paap, R and Viaene, J. M. 2008. "The trade and FDI effects of EMU enlargement." Journal of International Money and Finance, 27(2), 188-208.

[21] Camarero, M., Gómez - Herrera, E., and Tamarit, C. 2018. "New evidence on Trade and FDI: How large is the Euro effect?. Open Economies Review, 29(2), 451-467.

[22] Chakrabarti, A. 2001. "The determinants of foreign direct investment: Sensitivity analysis of cross-country regressions". Kyklos, 54(1), 89-114.

[23] De Sousa, J., Mayer, T and Zignago, S. 2012. "Market access in global and regional trade". Regional Science and Urban Economics, 42(6), 1037- 1052.

[24] Desbordes, Rodolphe and Vicard, Vincent. 2009. "Foreign direct investment and bilateral investment treaties: An international political perspective". Journal of Comparative Economics, vol. 37(3), pages 372-386.

[25] Djankov, S., Ganser, T., McLiesh, C., Ramalho, R. and Shleifer, A. 2010. "The effect of corporate taxes on invest-ment and entrepreneurship". American Economic Journal: Macroeconomics, 2(3), 31-64.

[26] Dritsaki, C., and Stiakakis, E .2014. "Foreign Direct Investments, Exports, and Economic Growth in Croatia: A Time Series Analysis". Procedia Economics and Finance, 14, 181-190.

[27] Egger, Peter and Valeria Merlo. 2007. "The Impact of Bilateral Investment Treaties on FDI Dynamics". The World Economy, vol. 30(10), pages 1536-1549.

[28] Eicher, T. S., Helfman, L., and Lenkoski, A. 2012. "Robust FDI determinants: Bayesian model averaging in the presence of selection bias". Journal of Macroeconomics, 34(3), 637-651.

[29] Ethier and Markusen. 1996. "Multinational Firms, Technology Diffusion and Trade". Journal of International Economic. Vol. 41, No. 1-2, pp. 1-28.

[30] Fernando Mistura and Caroline Roulet. 2019. "The determinants of Foreign Direct Investment: Do statutory restrictions matter?". OECD Working Papers on International Investment 2019/01, OECD Publishing.

[31] Fournier, J.M. 2015. "The negative effect of regulatory divergence on foreign direct investment". OECD Economics Department Working Papers 1268, OECD Publishing.

[32] Gregori, Wildmer and Nardo, Michela. 2021. "The effect of restrictive measures on cross-border investment in the European Union. The World Economy, Forthcoming.

[33] Hale, G and Xu, M. 2016. "FDI effects on the labor market of host countries". Federal Reserve Bank of San Francisco, working paper series, 2016-25.

[34] Gherghina, S., Simionescu, L., and Hudea, O. 2019. "Exploring foreign direct investments - Economic growth nexus. Empirical evidence from Central and Eastern European countries." Sustainability, 11(19), 5421 
[35] Ghosh, M., Syntetos, P. and Wang, W. 2012. "Impact of FDI restrictions on inward FDI in OECD countries". Global Economy Journal, Vol 12(3).

[36] Golub, S. et al. 2003. "The Influence of Policies on Trade and Foreign Direct Investment". OECD Economic Studies, No. 36, pp. 7-83.

[37] Gulen, H and Ion, M. 2015. "Policy uncertainty and corporate investment". Rev. Financ. Stud. 29 (3), 523-564.

[38] Head, Keith and Ries, John. 2008. "FDI as an outcome of the market for corporate control: Theory and evidence". Journal of International Economics, vol. 74(1), pages 2-20.

[39] Heid, B and Larch, M. (2016). "Gravity with unemployment". Journal of International Economics, 101, 70- 85.

[40] Jonathan Batten and Xuan Vinh Vo. 2009. "An analysis of the relationship between foreign direct investment and economic growth". Applied Economics, Taylor and Francis Journals, vol. 41(13), pages 1621-1641.

[41] Kleinert, J. and Toubal, F. 2010. "Gravity for FDI". Review of International Economics, 18, $1-13$.

[42] Koyama, T. and Golub, S. 2006. "OECD's FDI Regulatory Restrictiveness Index: Revision and extension to more economies". OECD Working Paper on International Investment.

[43] Kox, Henk and Rojas-Romagosa, Hugo. 2019. "Gravity Estimations with FDI Bilateral Data: Potential FDI Effects of Deep Preferential Trade Agreements". Robert Schuman Centre for Advanced Studies Research.

[44] Iamsiraroj, S and Doucouliagos, H. 2015. "Does Growth Attract FDI?". Economics, 9(19), 1.

[45] Li, X., and Liu, X. 2005. "Foreign direct investment and economic growth: an increasingly endogenous relationship". World development, 33 (3), 393-407.

[46] Martínez - San Román, V., Bengoa, M., and Sánchez - Robles, B. 2016. "Foreign direct investment, trade integration and the home bias: Evidence from the European Union". Empirical Economics, 50(1), 197-229

[47] Nicoletti, G., Golub, S. S., Hajkova, D., Mirza, D. and Yoo, K.-Y. 2003 "The Influence of Policies on Trade and Foreign Direct Investment". OECD Economic Studies No. 36, 2003/1, OECD Publishing, Paris.

[48] Nurnaddia Nordin; Nurhaiza Nordin; Murni Yunus Mawar and orzalina Zainudin. 2019. "Growth Effect Of Foreign Direct Investment: The Role Of Labor Market Flexibility". Economic Journal of Emerging Markets, Universitas Islam Indonesia, Department of Economics, vol. 11(1), pages 19-31.

[49] Nordås, HK and Rouzet, D. 2017. "The Impact of Services Trade Restrictiveness on Trade Flows". The World Economy, Volume 40, Issue 6, 1155-1183.

[50] OECD. 2015. "Implementing the latest international standards for compiling foreign direct investment statistics". OECD.

[51] Olivero, Marí a Pí a and Yoto V. Yotov. 2012. "Dynamic Gravity: Endogenous Country Size and Asset Accumulation". Canadian Journal of Economics, 2012, 45 (1), 64-92.

[52] Rouzet, D. and F. Spinelli. 2016. "Services Trade Restrictiveness, Mark-Ups and Competition". OECD Trade Policy Papers, No. 194, OECD Publishing, Paris. 
[53] Santos Silva, J and Silvana Tenreyro. 2006. "The Log of Gravity". The Review of Economics and Statistics, 88(4): 6416-658.

[54] Silva, J. S and Tenreyro, S. 2011. Poisson: Some convergence issues. The Stata Journal, 11(2), 207-212.

[55] Tobin, J. and S. Rose-Ackerman. 2005. "Foreign Direct Investment and the Business Environment in Developing Countries: the Impact of Bilateral Investment Treaties". Center for Law, Economics and Public Policy, Research Paper No. 293.

[56] UNCTAD. 2019. "World Investment Report 2019". United Nations Conference On Trade and Development.

[57] Van der Marel Erik and Shepherd Ben. 2013. "Services Trade, Regulation and Regional Integration: Evidence from Sectoral Data". The World Economy, 36, nº11 (2013): 1393-1405.

[58] Wei, Shang-Jin. 2000. "How Taxing is Corruption on International Investors?" . Review of Economics and Statistics. 82 (1): 1-11.

[59] World Bank. 2005. " A better investment climate for everyone". World development report. Washington, DC : World Bank Group.

[60] Yotov, Y.V., Piermartini, R., Monteiro, J-A., Larch, M. 2016. "An advanced guide to trade policy analysis: The structural gravity model". United Nations and World Trade Organization. Geneva.

[61] Zongo Amara. 2021. "The Impact of Services Trade Restrictiveness on Food Trade". International Economics, Vol 166, 71-94. 
Table 1: OECD outward and inward FDI stocks by sector (\% of total FDI)

\begin{tabular}{|c|c|c|c|c|c|c|c|c|}
\hline \multirow[t]{2}{*}{ Years } & \multicolumn{2}{|c|}{2016} & \multicolumn{2}{|c|}{2017} & \multicolumn{2}{|c|}{2018} & \multicolumn{2}{|c|}{2019} \\
\hline & Inward & Outward & Inward & Outward & Inward & Outward & Inward & Outward \\
\hline \multicolumn{9}{|l|}{ Agriculture, forestry, } \\
\hline fishing and mining & 0.73 & 0.29 & 0.82 & 0.3 & 0.79 & 1.1 & 1.08 & 2.14 \\
\hline Manufacturing sector & 23.04 & 21.99 & 23.98 & 22.71 & 22.87 & 23.44 & 23.07 & 20.6 \\
\hline Service sector & 63.48 & 60.46 & 62.44 & 61.75 & 64.22 & 61.23 & 62.47 & 62.38 \\
\hline
\end{tabular}

Source: Author's calculation based on OECD FDI data

${ }^{34}$ The partner country is the world. 
Table 2: Gravity Estimation Results of Impacts of Restrictive Measures on FDI Stocks: Intra-OECD countries

\begin{tabular}{|c|c|c|c|c|c|c|c|c|}
\hline \multirow[t]{2}{*}{$\begin{array}{l}\text { Specification } \\
\text { Dependant variable } \\
\text { Years } \\
\text { Model }\end{array}$} & \multicolumn{8}{|c|}{$\begin{array}{c}\text { PPML Estimate } \\
\frac{F D I_{i j, t}}{\text { GDPdeflator }_{i j, t}} \\
\mathbf{2 0 1 0 - 2 0 1 9}\end{array}$} \\
\hline & (1) & $(2)$ & (3) & (4) & (5) & $(6)$ & $(7)$ & (8) \\
\hline FDIRI Global ${ }_{j, t-1}$ & $\begin{array}{l}-0.9684 \\
(1.1535)\end{array}$ & $\begin{array}{l}-0.7067 \\
(1.1299)\end{array}$ & $\begin{array}{l}-1.5775 \\
(1.2897)\end{array}$ & $\begin{array}{l}-1.4577 \\
(1.2565)\end{array}$ & & & & \\
\hline FDI RI Primary ${ }_{j, t-1}$ & & & & & $\begin{array}{l}1.0655 \\
(0.8421)\end{array}$ & $\begin{array}{l}1.1570 \\
(0.7943)\end{array}$ & $\begin{array}{l}1.1757^{*} \\
(0.6918)\end{array}$ & $\begin{array}{l}1.0851 \\
(0.6599)\end{array}$ \\
\hline FDI RI Secondary $y_{j, t-1}$ & & & & & $\begin{array}{l}0.9040 \\
(1.2758)\end{array}$ & $\begin{array}{l}1.1388 \\
(1.2120)\end{array}$ & $\begin{array}{l}0.4176 \\
(1.6173)\end{array}$ & $\begin{array}{l}0.5394 \\
(1.5702)\end{array}$ \\
\hline FDI RI Tertiary ${ }_{j, t-1}$ & & & & & $\begin{array}{l}-2.6733^{*} \\
(1.4024)\end{array}$ & $\begin{array}{l}-2.6431^{*} \\
(1.3860)\end{array}$ & $\begin{array}{l}-3.3697^{* *} \\
(1.5783)\end{array}$ & $\begin{array}{l}-3.2017^{* *} \\
(1.5114)\end{array}$ \\
\hline $\operatorname{Ln} F D I_{i j, t-1}$ & $\begin{array}{l}1.3921^{* * *} \\
(0.0608)\end{array}$ & $\begin{array}{l}1.4414^{* * *} \\
(0.0634)\end{array}$ & $\begin{array}{l}0.6660^{* * *} \\
(0.0627)\end{array}$ & $\begin{array}{l}0.7409^{* * *} \\
(0.0642)\end{array}$ & $\begin{array}{l}1.3806^{* * *} \\
(0.0593)\end{array}$ & $\begin{array}{l}1.4331^{* * *} \\
(0.0604)\end{array}$ & $\begin{array}{l}0.6574^{* * *} \\
(0.0620)\end{array}$ & $\begin{array}{l}0.7309^{* * *} \\
(0.0641)\end{array}$ \\
\hline Ln distance $_{i j, t-1}$ & $\begin{array}{l}-0.7392^{* * *} \\
(0.1486)\end{array}$ & $\begin{array}{l}-0.6847^{* * *} \\
(0.1264)\end{array}$ & $\begin{array}{l}-0.7486^{* * *} \\
(0.1110)\end{array}$ & $\begin{array}{l}-0.6828^{* * *} \\
(0.1065)\end{array}$ & $\begin{array}{l}-0.7635^{* * *} \\
(0.1595)\end{array}$ & $\begin{array}{l}-0.7065^{* * *} \\
(0.1342)\end{array}$ & $\begin{array}{l}-0.7681^{* * *} \\
(0.1275)\end{array}$ & $\begin{array}{l}-0.7002^{* * *} \\
(0.1214)\end{array}$ \\
\hline Common border ${ }_{i j, t-1}$ & $\begin{array}{l}-0.2457^{* *} \\
(0.1183)\end{array}$ & $\begin{array}{l}-0.2539^{* *} \\
(0.1046)\end{array}$ & $\begin{array}{l}-0.2492^{* *} \\
(0.1138)\end{array}$ & $\begin{array}{l}-0.2408^{* *} \\
(0.1096)\end{array}$ & $\begin{array}{l}-0.2294^{*} \\
(0.1253)\end{array}$ & $\begin{array}{l}-0.2344^{* *} \\
(0.1103)\end{array}$ & $\begin{array}{l}-0.2210^{* *} \\
(0.1093)\end{array}$ & $\begin{array}{l}-0.2150^{* *} \\
(0.1056)\end{array}$ \\
\hline Common $\operatorname{lang}_{i j, t-1}$ & $\begin{array}{l}0.1162 \\
(0.1175)\end{array}$ & $\begin{array}{l}0.0851 \\
(0.1110)\end{array}$ & $\begin{array}{l}0.1324 \\
(0.1060)\end{array}$ & $\begin{array}{l}0.1198 \\
(0.1004)\end{array}$ & $\begin{array}{l}0.1096 \\
(0.1208)\end{array}$ & $\begin{array}{l}0.0790 \\
(0.1119)\end{array}$ & $\begin{array}{l}0.1419 \\
(0.1059)\end{array}$ & $\begin{array}{l}0.1291 \\
(0.1005)\end{array}$ \\
\hline Colonial links $s_{i j, t-1}$ & $\begin{array}{l}0.0798 \\
(0.1753)\end{array}$ & $\begin{array}{l}0.0705 \\
(0.1621)\end{array}$ & $\begin{array}{l}0.2398^{* *} \\
(0.1181)\end{array}$ & $\begin{array}{l}0.2322^{* *} \\
(0.1159)\end{array}$ & $\begin{array}{l}0.0469 \\
(0.1795)\end{array}$ & $\begin{array}{l}0.0365 \\
(0.1641)\end{array}$ & $\begin{array}{l}0.1867 \\
(0.1158)\end{array}$ & $\begin{array}{l}0.1835 \\
(0.1137)\end{array}$ \\
\hline$R T A_{i j, t-1}$ & $\begin{array}{l}-0.4967^{* * *} \\
(0.1446)\end{array}$ & $\begin{array}{l}-0.4430^{* * *} \\
(0.1438)\end{array}$ & $\begin{array}{l}0.1999 \\
(0.1238)\end{array}$ & $\begin{array}{l}0.2427^{* *} \\
(0.1136)\end{array}$ & $\begin{array}{l}-0.5057^{* * *} \\
(0.1519)\end{array}$ & $\begin{array}{l}-0.4543^{* * *} \\
(0.1526)\end{array}$ & $\begin{array}{l}0.2070 \\
(0.1401)\end{array}$ & $\begin{array}{l}0.2499^{*} \\
(0.1286)\end{array}$ \\
\hline$B I T_{i j, t-1}$ & $\begin{array}{c}-0.2125^{*} \\
(0.1151)\end{array}$ & $\begin{array}{l}-0.1991^{*} \\
(0.1092)\end{array}$ & $\begin{array}{l}-0.2181 \\
(0.1500)\end{array}$ & $\begin{array}{l}-0.1987 \\
(0.1425)\end{array}$ & $\begin{array}{l}-0.2631^{* *} \\
(0.1091)\end{array}$ & $\begin{array}{l}-0.2516^{* *} \\
(0.1039)\end{array}$ & $\begin{array}{l}-0.3515^{* *} \\
(0.1704)\end{array}$ & $\begin{array}{l}-0.3218^{* *} \\
(0.1620)\end{array}$ \\
\hline $\operatorname{Ln} G D P_{i, t-1}$ & $\begin{array}{l}0.2056^{* * *} \\
(0.0267)\end{array}$ & $\begin{array}{l}0.1414 \\
(0.1014)\end{array}$ & $\begin{array}{l}0.2175^{* * *} \\
(0.0255)\end{array}$ & $\begin{array}{l}-0.2783 \\
(0.1864)\end{array}$ & $\begin{array}{l}0.2044^{* * *} \\
(0.0265)\end{array}$ & $\begin{array}{l}0.1346 \\
(0.1007)\end{array}$ & $\begin{array}{l}0.2164^{* * *} \\
(0.0254)\end{array}$ & $\begin{array}{l}-0.2785 \\
(0.1871)\end{array}$ \\
\hline $\operatorname{Ln} G D P_{j, t-1}$ & $\begin{array}{l}0.6167^{* * *} \\
(0.1129)\end{array}$ & $\begin{array}{l}0.6371^{* * *} \\
(0.1073)\end{array}$ & $\begin{array}{l}1.6049^{* * *} \\
(0.1455)\end{array}$ & $\begin{array}{l}1.5614^{* * *} \\
(0.1427)\end{array}$ & $\begin{array}{l}0.5655^{* * *} \\
(0.1183)\end{array}$ & $\begin{array}{l}0.5830^{* * *} \\
(0.1129)\end{array}$ & $\begin{array}{l}1.5211^{* * *} \\
(0.1428)\end{array}$ & $\begin{array}{l}1.4865^{* * *} \\
(0.1407)\end{array}$ \\
\hline Trade openness $_{j, t-1}$ & $\begin{array}{l}0.3600^{* * *} \\
(0.0912)\end{array}$ & $\begin{array}{l}0.3741^{* * *} \\
(0.0925)\end{array}$ & $\begin{array}{l}0.9315^{* * *} \\
(0.1011)\end{array}$ & $\begin{array}{l}0.9049^{* * *} \\
(0.1001)\end{array}$ & $\begin{array}{l}0.3490^{* * *} \\
(0.0882)\end{array}$ & $\begin{array}{l}0.3634^{* * *} \\
(0.0879)\end{array}$ & $\begin{array}{l}0.9139^{* * *} \\
(0.0974)\end{array}$ & $\begin{array}{l}0.8896^{* * *} \\
(0.0967)\end{array}$ \\
\hline Regulatory quality $_{j, t-1}$ & $\begin{array}{l}0.1178^{* * *} \\
(0.0367)\end{array}$ & $\begin{array}{l}0.0555 \\
(0.0408)\end{array}$ & $\begin{array}{l}0.1755^{* * *} \\
(0.0425)\end{array}$ & $\begin{array}{l}0.1206^{* * *} \\
(0.0442)\end{array}$ & $\begin{array}{l}0.1173^{* * *} \\
(0.0356)\end{array}$ & $\begin{array}{l}0.0524 \\
(0.0392)\end{array}$ & $\begin{array}{l}0.1763^{* * *} \\
(0.0412)\end{array}$ & $\begin{array}{l}0.1209^{* * *} \\
(0.0430)\end{array}$ \\
\hline Ln productivity ${ }_{j, t-1}$ & $\begin{array}{l}0.0196 \\
(0.5484)\end{array}$ & $\begin{array}{l}0.2710 \\
(0.5456)\end{array}$ & $\begin{array}{l}0.6613 \\
(0.4474)\end{array}$ & $\begin{array}{l}0.8190^{*} \\
(0.4410)\end{array}$ & $\begin{array}{l}-0.0842 \\
(0.5182)\end{array}$ & $\begin{array}{l}0.1468 \\
(0.5127)\end{array}$ & $\begin{array}{l}0.4299 \\
(0.4412)\end{array}$ & $\begin{array}{l}0.5964 \\
(0.4350)\end{array}$ \\
\hline Ln tax burden $_{j, t-1}$ & $\begin{array}{l}0.0129 \\
(0.6223)\end{array}$ & $\begin{array}{l}0.1087 \\
(0.5920)\end{array}$ & $\begin{array}{l}0.0588 \\
(0.6089)\end{array}$ & $\begin{array}{l}0.1611 \\
(0.6004)\end{array}$ & $\begin{array}{l}0.2634 \\
(0.5915)\end{array}$ & $\begin{array}{l}0.3527 \\
(0.5499)\end{array}$ & $\begin{array}{l}0.2314 \\
(0.5867)\end{array}$ & $\begin{array}{l}0.3245 \\
(0.5758)\end{array}$ \\
\hline$H C D_{i j, t-1}$ & $\begin{array}{l}-0.9895 \\
(0.9527)\end{array}$ & $\begin{array}{l}-1.7054^{*} \\
(0.9159)\end{array}$ & $\begin{array}{l}0.2990 \\
(1.2344)\end{array}$ & $\begin{array}{l}-0.0398 \\
(1.1792)\end{array}$ & $\begin{array}{l}-1.1331 \\
(0.9418)\end{array}$ & $\begin{array}{l}-1.8124^{* *} \\
(0.9034)\end{array}$ & $\begin{array}{l}-0.0916 \\
(1.2924)\end{array}$ & $\begin{array}{l}-0.3689 \\
(1.2312)\end{array}$ \\
\hline Ln Labor freedom ${ }_{j, t-1}$ & $\begin{array}{l}0.7091^{*} \\
(0.3874)\end{array}$ & $\begin{array}{l}0.5527^{*} \\
(0.3199)\end{array}$ & $\begin{array}{l}1.9088^{* * *} \\
(0.4627)\end{array}$ & $\begin{array}{l}1.7763^{* * *} \\
(0.4482)\end{array}$ & $\begin{array}{l}0.7295^{*} \\
(0.3991)\end{array}$ & $\begin{array}{l}0.5615^{*} \\
(0.3293)\end{array}$ & $\begin{array}{l}1.9387^{* * *} \\
(0.4669)\end{array}$ & $\begin{array}{l}1.8071^{* * *} \\
(0.4547)\end{array}$ \\
\hline $\begin{array}{l}\text { Time - FE } \\
\text { Country - FE }\end{array}$ & $\begin{array}{l}\text { No } \\
\text { No }\end{array}$ & $\begin{array}{l}\text { Yes } \\
\text { No }\end{array}$ & $\begin{array}{l}\text { No } \\
\text { Yes }\end{array}$ & $\begin{array}{l}\text { Yes } \\
\text { Yes }\end{array}$ & $\begin{array}{l}\mathrm{No} \\
\mathrm{No}\end{array}$ & $\begin{array}{l}\text { Yes } \\
\text { No }\end{array}$ & $\begin{array}{l}\text { No } \\
\text { Yes }\end{array}$ & $\begin{array}{l}\text { Yes } \\
\text { Yes }\end{array}$ \\
\hline$R^{2}$ & 0.7644 & 0.7742 & 0.8330 & 0.8371 & 0.7656 & 0.7754 & 0.8345 & 0.8384 \\
\hline Observations & 12391 & 12391 & 12391 & 12391 & 12391 & 12391 & 12391 & 12391 \\
\hline
\end{tabular}


Table 3: Gravity Estimation Results of Impacts of Restrictive Measures on FDI Stocks: OECD vs. Emerging countries

\begin{tabular}{|c|c|c|c|c|c|c|c|c|}
\hline \multirow{3}{*}{$\begin{array}{l}\text { Model } \\
\text { FDIRI Global } \\
j, t-1\end{array}$} & \multicolumn{4}{|c|}{ FDI RI global } & \multicolumn{4}{|c|}{ Sectoral FDI RI } \\
\hline & (1) & (2) & & & (5) & (6) & (7) & (8) \\
\hline & $\begin{array}{l}-0.8966 \\
(1.2328)\end{array}$ & $\begin{array}{l}-0.6555 \\
(1.3337)\end{array}$ & $\begin{array}{l}-2.7090^{* * *} \\
(0.8676)\end{array}$ & $\begin{array}{l}-2.8372^{* * *} \\
(0.8605)\end{array}$ & & & & \\
\hline FDI RI Primary $y_{j, t-1}$ & & & & & $\begin{array}{l}3.6750^{* *} \\
(1.8083)\end{array}$ & $\begin{array}{l}2.4437 \\
(2.1133)\end{array}$ & $\begin{array}{l}0.7382 \\
(1.6106)\end{array}$ & $\begin{array}{l}1.9517 \\
(1.6061)\end{array}$ \\
\hline FDI RI Secondary $y_{j, t-1}$ & & & & & $\begin{array}{l}3.1933 \\
(2.6091)\end{array}$ & $\begin{array}{l}3.9684 \\
(2.7213)\end{array}$ & $\begin{array}{l}2.4651 \\
(1.5354)\end{array}$ & $\begin{array}{l}2.2995 \\
(1.6283)\end{array}$ \\
\hline FDI RI Tertiary $j_{j, t-1}$ & & & & & $\begin{array}{l}-6.1587^{* *} \\
(2.7217)\end{array}$ & $\begin{array}{l}-5.0693^{*} \\
(2.9055)\end{array}$ & $\begin{array}{l}-4.1793^{* *} \\
(1.7590)\end{array}$ & $\begin{array}{l}-5.4537^{* * *} \\
(1.9009)\end{array}$ \\
\hline OECD dum ${ }_{j} *$ FDI RI Global & $\begin{array}{l}-0.4176 \\
(2.6573)\end{array}$ & $\begin{array}{l}-0.9677 \\
(2.6496)\end{array}$ & $\begin{array}{l}1.0522 \\
(1.6975)\end{array}$ & $\begin{array}{l}1.8073 \\
(1.9091)\end{array}$ & & & & \\
\hline 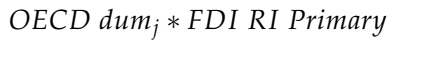 & & & & & $\begin{array}{l}-1.5790 \\
(2.5561)\end{array}$ & $\begin{array}{l}-0.1979 \\
(2.8042)\end{array}$ & $\begin{array}{l}0.8708 \\
(1.7777)\end{array}$ & $\begin{array}{l}-0.3874 \\
(1.8106)\end{array}$ \\
\hline 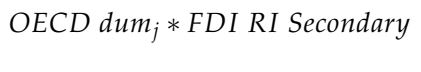 & & & & & $\begin{array}{l}-2.9205 \\
(3.3093)\end{array}$ & $\begin{array}{l}-3.3730 \\
(3.2836)\end{array}$ & $\begin{array}{l}-2.3615 \\
(2.5308)\end{array}$ & $\begin{array}{l}-1.9885 \\
(2.6015)\end{array}$ \\
\hline OECD dum ${ }_{j} *$ FDI RI Tertiary & & & & & $\begin{array}{l}2.5216 \\
(3.6011)\end{array}$ & $\begin{array}{l}0.7075 \\
(3.7849)\end{array}$ & $\begin{array}{l}0.5918 \\
(2.4709)\end{array}$ & $\begin{array}{l}2.2627 \\
(2.8830)\end{array}$ \\
\hline OECD dum & $\begin{array}{l}-0.3455 \\
(0.4544)\end{array}$ & $\begin{array}{l}-0.5656 \\
(0.4343)\end{array}$ & $\begin{array}{l}0.2383 \\
(0.2899)\end{array}$ & $\begin{array}{l}1.6942^{* * *} \\
(0.5514)\end{array}$ & $\begin{array}{l}-0.3795 \\
(0.4242)\end{array}$ & $\begin{array}{l}-0.6101 \\
(0.4061)\end{array}$ & $\begin{array}{l}0.1558 \\
(0.3015)\end{array}$ & $\begin{array}{l}1.4498^{* * *} \\
(0.5021)\end{array}$ \\
\hline $\operatorname{Ln} F D I_{i j, t-1}$ & $\begin{array}{l}0.1768^{* * *} \\
(0.0634)\end{array}$ & $\begin{array}{l}0.1169 \\
(0.0731)\end{array}$ & $\begin{array}{l}0.2169^{* * *} \\
(0.0449)\end{array}$ & $\begin{array}{l}0.1037^{* *} \\
(0.0482)\end{array}$ & $\begin{array}{l}0.1697^{* * *} \\
(0.0645)\end{array}$ & $\begin{array}{l}0.1053 \\
(0.0747)\end{array}$ & $\begin{array}{l}0.2132^{* * *} \\
(0.0430)\end{array}$ & $\begin{array}{l}0.1031^{* *} \\
(0.0457)\end{array}$ \\
\hline$L n$ distance $_{i j, t-1}$ & $\begin{array}{l}-1.9369^{* * *} \\
(0.2594)\end{array}$ & $\begin{array}{l}-1.9332^{* * *} \\
(0.2639)\end{array}$ & $\begin{array}{l}-1.0958^{* * *} \\
(0.1336)\end{array}$ & $\begin{array}{l}-1.1267^{* * *} \\
(0.1373)\end{array}$ & $\begin{array}{l}-1.9735^{* * *} \\
(0.2662)\end{array}$ & $\begin{array}{l}-1.9679^{* * *} \\
(0.2711)\end{array}$ & $\begin{array}{l}-1.1196^{* * *} \\
(0.1449)\end{array}$ & $\begin{array}{l}-1.1546^{* * *} \\
(0.1504)\end{array}$ \\
\hline Common border $_{i j, t-1}$ & $\begin{array}{l}-0.5249^{*} \\
(0.2757)\end{array}$ & $\begin{array}{l}-0.4980^{*} \\
(0.2754)\end{array}$ & $\begin{array}{l}-0.4240^{* * *} \\
(0.1497)\end{array}$ & $\begin{array}{l}-0.4442^{* * *} \\
(0.1512)\end{array}$ & $\begin{array}{l}-0.4977^{*} \\
(0.2833)\end{array}$ & $\begin{array}{l}-0.4692^{*} \\
(0.2834)\end{array}$ & $\begin{array}{l}-0.3903^{* * *} \\
(0.1444)\end{array}$ & $\begin{array}{l}-0.4130^{* * *} \\
(0.1456)\end{array}$ \\
\hline Common lang $i j, t-1$ & $\begin{array}{l}0.5088^{*} \\
(0.2708)\end{array}$ & $\begin{array}{l}0.5194^{*} \\
(0.2709)\end{array}$ & $\begin{array}{l}0.3148^{* *} \\
(0.1485)\end{array}$ & $\begin{array}{l}0.2863^{*} \\
(0.1499)\end{array}$ & $\begin{array}{l}0.5073^{*} \\
(0.2722)\end{array}$ & $\begin{array}{l}0.5180^{*} \\
(0.2717)\end{array}$ & $\begin{array}{l}0.3263^{* *} \\
(0.1469)\end{array}$ & $\begin{array}{l}0.3000^{* *} \\
(0.1485)\end{array}$ \\
\hline Colonial links $s_{i j, t-1}$ & $\begin{array}{l}0.6041^{*} \\
(0.3408)\end{array}$ & $\begin{array}{l}0.5745^{*} \\
(0.3441)\end{array}$ & $\begin{array}{l}0.3702^{* *} \\
(0.1551)\end{array}$ & $\begin{array}{l}0.3773^{* *} \\
(0.1575)\end{array}$ & $\begin{array}{l}0.5405 \\
(0.3492)\end{array}$ & $\begin{array}{l}0.5022 \\
(0.3526)\end{array}$ & $\begin{array}{l}0.3104^{* *} \\
(0.1485)\end{array}$ & $\begin{array}{l}0.3199^{* *} \\
(0.1534)\end{array}$ \\
\hline$B I T_{i j, t-1}$ & $\begin{array}{l}-0.6934^{* * *} \\
(0.1708)\end{array}$ & $\begin{array}{l}-0.7063^{* * *} \\
(0.1692)\end{array}$ & $\begin{array}{l}-0.3866^{* *} \\
(0.1730)\end{array}$ & $\begin{array}{l}-0.3391^{*} \\
(0.1782)\end{array}$ & $\begin{array}{l}-0.7346^{* * *} \\
(0.1692)\end{array}$ & $\begin{array}{l}-0.7567^{* * *} \\
(0.1676)\end{array}$ & $\begin{array}{l}-0.5114^{* * *} \\
(0.1833)\end{array}$ & $\begin{array}{l}-0.4623^{* *} \\
(0.1909)\end{array}$ \\
\hline$R T A_{i j, t-1}$ & $\begin{array}{l}-0.6204^{* *} \\
(0.2515)\end{array}$ & $\begin{array}{l}-0.6385^{* *} \\
(0.2530)\end{array}$ & $\begin{array}{l}0.3709^{* * *} \\
(0.1398)\end{array}$ & $\begin{array}{l}0.3363^{* *} \\
(0.1447)\end{array}$ & $\begin{array}{l}-0.6671^{* *} \\
(0.2608)\end{array}$ & $\begin{array}{l}-0.6846^{* * *} \\
(0.2626)\end{array}$ & $\begin{array}{l}0.3624^{* *} \\
(0.1526)\end{array}$ & $\begin{array}{l}0.3220^{* *} \\
(0.1580)\end{array}$ \\
\hline $\operatorname{Ln} G D P_{i, t-1}$ & $\begin{array}{l}0.8362^{* * *} \\
(0.2577)\end{array}$ & $\begin{array}{l}0.8386^{* * *} \\
(0.2558)\end{array}$ & $\begin{array}{l}0.2004^{* * *} \\
(0.0300)\end{array}$ & $\begin{array}{l}-0.1195^{*} \\
(0.0702)\end{array}$ & $\begin{array}{l}0.8210^{* * *} \\
(0.2589)\end{array}$ & $\begin{array}{l}0.8242^{* * *} \\
(0.2558)\end{array}$ & $\begin{array}{l}0.2028^{* * *} \\
(0.0302)\end{array}$ & $\begin{array}{l}-0.0990 \\
(0.0698)\end{array}$ \\
\hline$L n G D P_{j, t-1}$ & $\begin{array}{l}1.9802^{* * *} \\
(0.1802)\end{array}$ & $\begin{array}{l}1.9635^{* * *} \\
(0.1778)\end{array}$ & $\begin{array}{l}2.4362^{* * *} \\
(0.1315)\end{array}$ & $\begin{array}{l}2.4201^{* * *} \\
(0.1279)\end{array}$ & $\begin{array}{l}1.8389^{* * *} \\
(0.1735)\end{array}$ & $\begin{array}{l}1.8193^{* * *} \\
(0.1706)\end{array}$ & $\begin{array}{l}2.2892^{* * *} \\
(0.1277)\end{array}$ & $\begin{array}{l}2.2802^{* * *} \\
(0.1284)\end{array}$ \\
\hline Trade openness $s_{j, t-1}$ & $\begin{array}{l}1.1750^{* * *} \\
(0.1777)\end{array}$ & $\begin{array}{l}1.1578^{* * *} \\
(0.1775)\end{array}$ & $\begin{array}{l}1.4634^{* * *} \\
(0.1156)\end{array}$ & $\begin{array}{l}1.4140^{* * *} \\
(0.1158)\end{array}$ & $\begin{array}{l}1.1263^{* * *} \\
(0.1769)\end{array}$ & $\begin{array}{l}1.1083^{* * *} \\
(0.1761)\end{array}$ & $\begin{array}{l}1.4033^{* * *} \\
(0.1113)\end{array}$ & $\begin{array}{l}1.3548^{* * *} \\
(0.1132)\end{array}$ \\
\hline Regulatory quality $y_{j, t-1}$ & $\begin{array}{l}0.1976^{* *} \\
(0.0864)\end{array}$ & $\begin{array}{l}0.2004^{* *} \\
(0.0907)\end{array}$ & $\begin{array}{l}0.1847^{* * *} \\
(0.0632)\end{array}$ & $\begin{array}{l}0.1654^{* *} \\
(0.0650)\end{array}$ & $\begin{array}{l}0.1744^{* *} \\
(0.0814)\end{array}$ & $\begin{array}{l}0.1799^{* *} \\
(0.0856)\end{array}$ & $\begin{array}{l}0.1708^{* * *} \\
(0.0607)\end{array}$ & $\begin{array}{l}0.1545^{* *} \\
(0.0621)\end{array}$ \\
\hline Ln productivity $j_{j, t-1}$ & $\begin{array}{l}-0.0406 \\
(0.1155)\end{array}$ & $\begin{array}{l}-0.1748 \\
(0.1360)\end{array}$ & $\begin{array}{l}0.2163^{* * *} \\
(0.0730)\end{array}$ & $\begin{array}{l}0.7602^{* * *} \\
(0.1843)\end{array}$ & $\begin{array}{l}0.0354 \\
(0.1133)\end{array}$ & $\begin{array}{l}-0.1158 \\
(0.1430)\end{array}$ & $\begin{array}{l}0.2344^{* * *} \\
(0.0720)\end{array}$ & $\begin{array}{l}0.7258^{* * *} \\
(0.1713)\end{array}$ \\
\hline Ln tax burden ${ }_{j, t-1}$ & $\begin{array}{l}-0.9732 \\
(0.8637)\end{array}$ & $\begin{array}{l}-1.0849 \\
(0.8601)\end{array}$ & $\begin{array}{l}-0.3006 \\
(0.6583)\end{array}$ & $\begin{array}{l}-0.1956 \\
(0.6736)\end{array}$ & $\begin{array}{l}-0.4617 \\
(0.8747)\end{array}$ & $\begin{array}{l}-0.5172 \\
(0.8856)\end{array}$ & $\begin{array}{l}0.0377 \\
(0.6469)\end{array}$ & $\begin{array}{l}0.1495 \\
(0.6670)\end{array}$ \\
\hline$H C D_{i j, t-1}$ & $\begin{array}{l}-6.6256^{* * *} \\
(1.0754)\end{array}$ & $\begin{array}{l}-6.8341^{* * *} \\
(1.0605)\end{array}$ & $\begin{array}{l}-1.0753 \\
(1.1411)\end{array}$ & $\begin{array}{l}-0.4566 \\
(1.1578)\end{array}$ & $\begin{array}{l}-6.7128^{* * *} \\
(1.1023)\end{array}$ & $\begin{array}{l}-6.9120^{* * *} \\
(1.0865)\end{array}$ & $\begin{array}{l}-1.2443 \\
(1.1580)\end{array}$ & $\begin{array}{l}-0.6850 \\
(1.1653)\end{array}$ \\
\hline Ln Labor freedom $_{j, t-1}$ & $\begin{array}{l}1.7859^{* * *} \\
(0.6236)\end{array}$ & $\begin{array}{l}1.9592^{* * *} \\
(0.6439)\end{array}$ & $\begin{array}{l}2.3610^{* * *} \\
(0.5189)\end{array}$ & $\begin{array}{l}2.4041^{* * *} \\
(0.5323)\end{array}$ & $\begin{array}{l}1.8480^{* * *} \\
(0.6469)\end{array}$ & $\begin{array}{l}2.0308^{* * *} \\
(0.6710)\end{array}$ & $\begin{array}{l}2.3490^{* * *} \\
(0.5195)\end{array}$ & $\begin{array}{l}2.3783^{* * *} \\
(0.5384)\end{array}$ \\
\hline $\begin{array}{l}\text { Time-FE } \\
\text { Country -FE } \\
R^{2} \\
\text { Observations }\end{array}$ & $\begin{array}{l}\text { No } \\
\text { No } \\
0.5113 \\
19449\end{array}$ & $\begin{array}{l}\text { Yes } \\
\text { No } \\
0.5213 \\
19449\end{array}$ & $\begin{array}{l}\text { No } \\
\text { Yes } \\
0.7877 \\
19449\end{array}$ & $\begin{array}{l}\text { Yes } \\
\text { Yes } \\
0.7993 \\
19449\end{array}$ & $\begin{array}{l}\text { No } \\
\text { No } \\
0.5149 \\
19449\end{array}$ & $\begin{array}{l}\text { Yes } \\
\text { No } \\
0.5254 \\
19449\end{array}$ & $\begin{array}{l}\text { No } \\
\text { Yes } \\
0.7901 \\
19449\end{array}$ & $\begin{array}{l}\text { Yes } \\
\text { Yes } \\
0.8015 \\
19449\end{array}$ \\
\hline
\end{tabular}


Table 4: Gravity Estimation Results of Impacts of Restrictive Measures on FDI Stocks: OECD vs. Africa countries

\begin{tabular}{|c|c|c|c|c|c|c|c|c|}
\hline \multirow[b]{2}{*}{ Model } & \multicolumn{4}{|c|}{ FDI RI global } & \multicolumn{4}{|c|}{ Sectoral FDI RI } \\
\hline & $(1)$ & (2) & (3) & (4) & (5) & (6) & (7) & $(8)$ \\
\hline FDIRI Global ${ }_{j, t-1}$ & $\begin{array}{l}-2.5944 \\
(3.6069)\end{array}$ & $\begin{array}{l}4.2008 \\
(5.6213)\end{array}$ & $\begin{array}{l}-0.9225 \\
(3.5504)\end{array}$ & $\begin{array}{l}-1.6162 \\
(3.7637)\end{array}$ & & & & \\
\hline FDI RI Primary ${ }_{j, t-1}$ & & & & & $\begin{array}{l}2.1988 \\
(6.4698)\end{array}$ & $\begin{array}{l}-15.8533 \\
(19.2624)\end{array}$ & $\begin{array}{l}2.2433 \\
(4.1203)\end{array}$ & $\begin{array}{l}3.2496 \\
(4.0849)\end{array}$ \\
\hline FDI RI Secondary $y_{j, t-1}$ & & & & & $\begin{array}{l}18.9025 \\
(14.9815)\end{array}$ & $\begin{array}{l}-61.7042 \\
(46.0373)\end{array}$ & $\begin{array}{l}24.6712^{* *} \\
(9.6302)\end{array}$ & $\begin{array}{l}34.5852^{* * *} \\
(12.5787)\end{array}$ \\
\hline FDI RI Tertiary $y_{j, t-1}$ & & & & & $\begin{array}{l}-11.5606 \\
(9.9856)\end{array}$ & $\begin{array}{l}34.9320 \\
(26.9728)\end{array}$ & $\begin{array}{l}-13.7118^{* *} \\
(6.6913)\end{array}$ & $\begin{array}{l}-20.7709^{* *} \\
(9.0402)\end{array}$ \\
\hline OECD dum $m_{j} *$ FDI RI Global & $\begin{array}{l}0.3457 \\
(4.5099)\end{array}$ & $\begin{array}{l}-6.3800 \\
(6.1340)\end{array}$ & $\begin{array}{l}-0.7046 \\
(4.2073)\end{array}$ & $\begin{array}{l}-0.0712 \\
(4.4800)\end{array}$ & & & & \\
\hline 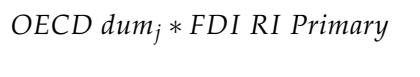 & & & & & $\begin{array}{l}0.4262 \\
(6.9738)\end{array}$ & $\begin{array}{l}19.0093 \\
(19.3923)\end{array}$ & $\begin{array}{l}-0.4726 \\
(4.2288)\end{array}$ & $\begin{array}{l}-1.5105 \\
(4.2092)\end{array}$ \\
\hline OECD dum $m_{j} *$ FDI RI Secondary & & & & & $\begin{array}{l}-19.3509 \\
(14.8862)\end{array}$ & $\begin{array}{l}62.0336 \\
(46.4781)\end{array}$ & $\begin{array}{l}-25.3630^{* * *} \\
(9.7697)\end{array}$ & $\begin{array}{l}-34.9111^{* * *} \\
(12.8049)\end{array}$ \\
\hline OECD dum $_{j} *$ FDI RI Tertiary & & & & & $\begin{array}{l}7.1248 \\
(10.2036)\end{array}$ & $\begin{array}{l}-40.4939 \\
(27.3846)\end{array}$ & $\begin{array}{l}10.4122 \\
(7.0042)\end{array}$ & $\begin{array}{l}17.1271^{*} \\
(9.6787)\end{array}$ \\
\hline OECD dum & $\begin{array}{l}0.9745^{*} \\
(0.5710)\end{array}$ & $\begin{array}{l}-0.2000 \\
(0.4262)\end{array}$ & $\begin{array}{l}1.1963^{* *} \\
(0.5064)\end{array}$ & $\begin{array}{l}1.9968^{*} \\
(1.1026)\end{array}$ & $\begin{array}{l}0.6024 \\
(0.4660)\end{array}$ & $\begin{array}{l}0.3135 \\
(0.5090)\end{array}$ & $\begin{array}{l}0.6126 \\
(0.4326)\end{array}$ & $\begin{array}{l}0.9346^{*} \\
(0.4899)\end{array}$ \\
\hline $\operatorname{Ln} F D I_{i j, t-1}$ & $\begin{array}{l}0.1614^{* *} \\
(0.0664)\end{array}$ & $\begin{array}{l}0.0909 \\
(0.0755)\end{array}$ & $\begin{array}{l}0.1970^{* * *} \\
(0.0460)\end{array}$ & $\begin{array}{l}0.0983^{* *} \\
(0.0489)\end{array}$ & $\begin{array}{l}0.1471^{* *} \\
(0.0680)\end{array}$ & $\begin{array}{l}0.0609 \\
(0.0781)\end{array}$ & $\begin{array}{l}0.1953^{* * *} \\
(0.0436)\end{array}$ & $\begin{array}{l}0.0960^{* *} \\
(0.0460)\end{array}$ \\
\hline Ln distance $_{i j, t-1}$ & $\begin{array}{l}-2.0158^{* * *} \\
(0.3097)\end{array}$ & $\begin{array}{l}-2.0291^{* * *} \\
(0.3126)\end{array}$ & $\begin{array}{l}-1.0735^{* * *} \\
(0.1492)\end{array}$ & $\begin{array}{l}-1.0968^{* * *} \\
(0.1550)\end{array}$ & $\begin{array}{l}-2.0293^{* * *} \\
(0.3105)\end{array}$ & $\begin{array}{l}-2.0688^{* * *} \\
(0.3099)\end{array}$ & $\begin{array}{l}-1.0890^{* * *} \\
(0.1630)\end{array}$ & $\begin{array}{l}-1.1107^{* * *} \\
(0.1723)\end{array}$ \\
\hline Common border $r_{i j, t-1}$ & $\begin{array}{l}-0.3751 \\
(0.2878)\end{array}$ & $\begin{array}{l}-0.3838 \\
(0.2874)\end{array}$ & $\begin{array}{l}-0.3946^{* *} \\
(0.1593)\end{array}$ & $\begin{array}{l}-0.4014^{* *} \\
(0.1602)\end{array}$ & $\begin{array}{l}-0.3320 \\
(0.2994)\end{array}$ & $\begin{array}{l}-0.3521 \\
(0.2985)\end{array}$ & $\begin{array}{l}-0.3441^{* *} \\
(0.1539)\end{array}$ & $\begin{array}{l}-0.3476^{* *} \\
(0.1542)\end{array}$ \\
\hline Common $\operatorname{lang}_{i j, t-1}$ & $\begin{array}{l}0.4299 \\
(0.2751)\end{array}$ & $\begin{array}{l}0.4519 \\
(0.2764)\end{array}$ & $\begin{array}{l}0.2730^{*} \\
(0.1535)\end{array}$ & $\begin{array}{l}0.2564^{*} \\
(0.1530)\end{array}$ & $\begin{array}{l}0.4255 \\
(0.2757)\end{array}$ & $\begin{array}{l}0.4391 \\
(0.2754)\end{array}$ & $\begin{array}{l}0.2751^{*} \\
(0.1509)\end{array}$ & $\begin{array}{l}0.2567^{*} \\
(0.1510)\end{array}$ \\
\hline Colonial links $s_{i j, t-1}$ & $\begin{array}{l}0.5617 \\
(0.3478)\end{array}$ & $\begin{array}{l}0.5116 \\
(0.3472)\end{array}$ & $\begin{array}{l}0.3795^{* *} \\
(0.1585)\end{array}$ & $\begin{array}{l}0.3816^{* *} \\
(0.1581)\end{array}$ & $\begin{array}{l}0.4791 \\
(0.3557)\end{array}$ & $\begin{array}{l}0.3929 \\
(0.3608)\end{array}$ & $\begin{array}{l}0.3200^{* *} \\
(0.1512)\end{array}$ & $\begin{array}{l}0.3222^{* *} \\
(0.1531)\end{array}$ \\
\hline$R T A_{i j, t-1}$ & $\begin{array}{l}-1.0383^{* * *} \\
(0.3298)\end{array}$ & $\begin{array}{l}-1.0083^{* * *} \\
(0.3221)\end{array}$ & $\begin{array}{l}0.4031^{* *} \\
(0.1568)\end{array}$ & $\begin{array}{l}0.3800^{* *} \\
(0.1650)\end{array}$ & $\begin{array}{l}-1.0757^{* * *} \\
(0.3391)\end{array}$ & $\begin{array}{l}-1.0353^{* * * *} \\
(0.3348)\end{array}$ & $\begin{array}{l}0.4143^{* *} \\
(0.1743)\end{array}$ & $\begin{array}{l}0.3940^{* *} \\
(0.1846)\end{array}$ \\
\hline$B I T_{i j, t-1}$ & $\begin{array}{l}-0.6872^{* * *} \\
(0.1853)\end{array}$ & $\begin{array}{l}-0.7202^{* * *} \\
(0.1858)\end{array}$ & $\begin{array}{l}-0.3623^{*} \\
(0.2012)\end{array}$ & $\begin{array}{c}-0.3486^{*} \\
(0.2064)\end{array}$ & $\begin{array}{l}-0.7402^{* * *} \\
(0.1824)\end{array}$ & $\begin{array}{l}-0.7920^{* * *} \\
(0.1838)\end{array}$ & $\begin{array}{l}-0.5241^{* *} \\
(0.2171)\end{array}$ & $\begin{array}{l}-0.5198^{* *} \\
(0.2239)\end{array}$ \\
\hline $\operatorname{Ln} G D P_{i, t-1}$ & $\begin{array}{l}0.7381^{* * *} \\
(0.2615)\end{array}$ & $\begin{array}{l}0.8008^{* * *} \\
(0.2094)\end{array}$ & $\begin{array}{l}0.2211^{* * *} \\
(0.0310)\end{array}$ & $\begin{array}{l}0.1099 \\
(0.1160)\end{array}$ & $\begin{array}{l}0.7229^{* * *} \\
(0.2605)\end{array}$ & $\begin{array}{l}0.8408^{* * *} \\
(0.2208)\end{array}$ & $\begin{array}{l}0.2225^{* * *} \\
(0.0307)\end{array}$ & $\begin{array}{l}0.1055 \\
(0.0978)\end{array}$ \\
\hline $\operatorname{Ln} G D P_{j, t-1}$ & $\begin{array}{l}1.8161^{* * *} \\
(0.1725)\end{array}$ & $\begin{array}{l}1.9712^{* * *} \\
(0.1715)\end{array}$ & $\begin{array}{l}2.4428^{* * *} \\
(0.1431)\end{array}$ & $\begin{array}{l}2.4123^{* * *} \\
(0.1469)\end{array}$ & $\begin{array}{l}1.6377^{* * *} \\
(0.1690)\end{array}$ & $\begin{array}{l}1.8315^{* * *} \\
(0.1787)\end{array}$ & $\begin{array}{l}2.2595^{* * *} \\
(0.1434)\end{array}$ & $\begin{array}{l}2.2303^{* * *} \\
(0.1461)\end{array}$ \\
\hline Trade openness $j_{j, t-1}$ & $\begin{array}{l}1.0658^{* * *} \\
(0.1745)\end{array}$ & $\begin{array}{l}1.2087^{* * *} \\
(0.1805)\end{array}$ & $\begin{array}{l}1.4650^{* * *} \\
(0.1161)\end{array}$ & $\begin{array}{l}1.4150^{* * *} \\
(0.1235)\end{array}$ & $\begin{array}{l}1.0249^{* * *} \\
(0.1737)\end{array}$ & $\begin{array}{l}1.2151^{* * *} \\
(0.1897)\end{array}$ & $\begin{array}{l}1.3935^{* * *} \\
(0.1112)\end{array}$ & $\begin{array}{l}1.3391^{* * *} \\
(0.1159)\end{array}$ \\
\hline Regulatory quality $y_{j, t-1}$ & $\begin{array}{l}0.1396 \\
(0.0967)\end{array}$ & $\begin{array}{l}0.2267^{* *} \\
(0.1059)\end{array}$ & $\begin{array}{l}0.1623^{* *} \\
(0.0645)\end{array}$ & $\begin{array}{l}0.1628^{* *} \\
(0.0675)\end{array}$ & $\begin{array}{l}0.1320 \\
(0.0883)\end{array}$ & $\begin{array}{l}0.2294^{* *} \\
(0.0988)\end{array}$ & $\begin{array}{l}0.1575^{* *} \\
(0.0620)\end{array}$ & $\begin{array}{l}0.1589^{* *} \\
(0.0648)\end{array}$ \\
\hline Ln productivity $y_{j, t-1}$ & $\begin{array}{l}0.5257^{* *} \\
(0.2137)\end{array}$ & $\begin{array}{l}-0.5647 \\
(0.5692)\end{array}$ & $\begin{array}{l}0.5537^{* * *} \\
(0.1551)\end{array}$ & $\begin{array}{l}0.8370^{* *} \\
(0.3921)\end{array}$ & $\begin{array}{l}0.5485^{* *} \\
(0.2419)\end{array}$ & $\begin{array}{l}-0.9420 \\
(0.7252)\end{array}$ & $\begin{array}{l}0.5923^{* * *} \\
(0.1529)\end{array}$ & $\begin{array}{l}0.8760^{* * *} \\
(0.3095)\end{array}$ \\
\hline Ln tax burden $_{j, t-1}$ & $\begin{array}{l}-0.5215 \\
(0.9023)\end{array}$ & $\begin{array}{l}-1.2559 \\
(1.0013)\end{array}$ & $\begin{array}{l}-0.0989 \\
(0.7090)\end{array}$ & $\begin{array}{l}-0.0404 \\
(0.7608)\end{array}$ & $\begin{array}{l}-0.0899 \\
(0.8914)\end{array}$ & $\begin{array}{l}-0.8208 \\
(1.0320)\end{array}$ & $\begin{array}{l}0.1228 \\
(0.6879)\end{array}$ & $\begin{array}{l}0.2298 \\
(0.7243)\end{array}$ \\
\hline$H C D_{i j, t-1}$ & $\begin{array}{l}-6.1623^{* * *} \\
(1.3752)\end{array}$ & $\begin{array}{l}-6.0969^{* * *} \\
(1.3453)\end{array}$ & $\begin{array}{l}-0.5337 \\
(1.5348)\end{array}$ & $\begin{array}{l}-0.1014 \\
(1.5285)\end{array}$ & $\begin{array}{l}-6.2865^{* * *} \\
(1.3563)\end{array}$ & $\begin{array}{l}-6.2358^{* * *} \\
(1.2903)\end{array}$ & $\begin{array}{l}-1.0182 \\
(1.5545)\end{array}$ & $\begin{array}{l}-0.5708 \\
(1.5509)\end{array}$ \\
\hline Ln Labor freedom $_{j, t-1}$ & $\begin{array}{l}1.7078^{* * *} \\
(0.6427)\end{array}$ & $\begin{array}{l}1.9831^{* * *} \\
(0.6534)\end{array}$ & $\begin{array}{l}2.5221^{* * *} \\
(0.5548)\end{array}$ & $\begin{array}{l}2.6334^{* * * *} \\
(0.5807)\end{array}$ & $\begin{array}{l}1.8549^{* * *} \\
(0.6566)\end{array}$ & $\begin{array}{l}2.2188^{* * *} \\
(0.6646)\end{array}$ & $\begin{array}{l}2.5635^{* * * *} \\
(0.5495)\end{array}$ & $\begin{array}{l}2.6697^{* * * *} \\
(0.5742)\end{array}$ \\
\hline $\begin{array}{l}\text { Time-FE } \\
\text { Country - FE } \\
R^{2} \\
\text { Observations }\end{array}$ & $\begin{array}{l}\text { No } \\
\text { No } \\
0.5173 \\
15213 \\
\end{array}$ & $\begin{array}{l}\text { Yes } \\
\text { No } \\
0.5343 \\
15213 \\
\end{array}$ & $\begin{array}{l}\text { No } \\
\text { Yes } \\
0.7955 \\
15213 \\
\end{array}$ & $\begin{array}{l}\text { Yes } \\
\text { Yes } \\
0.8039 \\
15213\end{array}$ & $\begin{array}{l}\text { No } \\
\text { No } \\
0.5221 \\
15213\end{array}$ & $\begin{array}{l}\text { Yes } \\
\text { No } \\
0.5420 \\
15213\end{array}$ & $\begin{array}{l}\text { No } \\
\text { Yes } \\
0.7982 \\
15213\end{array}$ & $\begin{array}{l}\text { Yes } \\
\text { Yes } \\
0.8070 \\
15213\end{array}$ \\
\hline
\end{tabular}


Table 5: Splitting the Time into Two Sub-Periods

\begin{tabular}{|c|c|c|c|c|c|c|c|c|c|c|c|c|}
\hline \multirow[b]{3}{*}{ Model } & \multicolumn{6}{|c|}{ 2010-2014 } & \multicolumn{6}{|c|}{ 2015-2019 } \\
\hline & \multicolumn{2}{|c|}{ OECD } & \multicolumn{2}{|c|}{$\begin{array}{l}\text { OECD vs } \\
\text { Emerging }\end{array}$} & \multicolumn{2}{|c|}{$\begin{array}{c}\text { OECD vs } \\
\text { Africa }\end{array}$} & \multicolumn{2}{|c|}{ OECD } & \multicolumn{2}{|c|}{$\begin{array}{l}\text { OECD vs } \\
\text { Emerging }\end{array}$} & \multicolumn{2}{|c|}{$\begin{array}{c}\text { OECD vs } \\
\text { Africa }\end{array}$} \\
\hline & $(1)$ & $(2)$ & (3) & $(4)$ & (5) & $(6)$ & $(7)$ & (8) & (9) & (10) & (11) & (12) \\
\hline FDI RI Global Glt-1 & $\begin{array}{l}-0.8035 \\
(1.5949)\end{array}$ & & $\begin{array}{l}-2.9042^{* * *} \\
(0.8700)\end{array}$ & & $\begin{array}{l}1.7913 \\
(3.6596)\end{array}$ & & $\begin{array}{l}-0.6455^{* *} \\
(0.2530)\end{array}$ & & $\begin{array}{l}-2.9875^{* * *} \\
(1.0427)\end{array}$ & & $\begin{array}{l}-2.1790 \\
(4.4139)\end{array}$ & \\
\hline FDI RI Primary & & $\begin{array}{l}0.3649 \\
(0.9116)\end{array}$ & & $\begin{array}{l}-0.7730 \\
(1.8619)\end{array}$ & & $\begin{array}{l}0.5863 \\
(4.7161)\end{array}$ & & $\begin{array}{l}0.4354^{* *} \\
(0.1771)\end{array}$ & & $\begin{array}{l}2.4512 \\
(1.6878)\end{array}$ & & $\begin{array}{l}4.0204 \\
(4.4847)\end{array}$ \\
\hline FDI RI Secondary & & $\begin{array}{l}-3.4786 \\
(2.3337)\end{array}$ & & $\begin{array}{l}4.7204^{* *} \\
(1.8759)\end{array}$ & & $\begin{array}{l}31.1855^{* *} \\
(14.1754)\end{array}$ & & $\begin{array}{l}0.2651 \\
(0.3253)\end{array}$ & & $\begin{array}{l}0.4153 \\
(1.8262)\end{array}$ & & $\begin{array}{l}32.8165^{* *} \\
(13.2715)\end{array}$ \\
\hline FDI RI Tertiary & & $\begin{array}{l}0.6948 \\
(2.1852)\end{array}$ & & $\begin{array}{l}--4.4398^{* *} \\
(2.0285)\end{array}$ & & $\begin{array}{l}-13.7059 \\
(10.3219)\end{array}$ & & $\begin{array}{l}-1.2520^{* * *} \\
(0.2832)\end{array}$ & & $\begin{array}{l}-4.8909^{* *} \\
(2.1449)\end{array}$ & & $\begin{array}{l}-18.3208^{*} \\
(10.0437)\end{array}$ \\
\hline OECD dum ${ }_{j} *$ & & & & & & & & & & & & \\
\hline FDI RI Global & & & $\begin{array}{l}2.6453 \\
(1.9471)\end{array}$ & & $\begin{array}{l}-2.6827 \\
(4.2966)\end{array}$ & & & & $\begin{array}{l}1.4609 \\
(2.2472)\end{array}$ & & $\begin{array}{l}0.1616 \\
(5.3016)\end{array}$ & \\
\hline$O E C D d u m_{j} *$ & & & & & & & & & & & & \\
\hline FDI RI Primary & & & & $\begin{array}{l}1.1214 \\
(2.0444)\end{array}$ & & $\begin{array}{l}-0.1415 \\
(4.7030)\end{array}$ & & & & $\begin{array}{l}-0.2583 \\
(1.9557)\end{array}$ & & $\begin{array}{l}-1.6392 \\
(4.7076)\end{array}$ \\
\hline$O E C D d u m_{j} *$ & & & & & & & & & & & & \\
\hline FDI RI Secondary & & & & $\begin{array}{l}-7.9898^{* * *} \\
(2.9645)\end{array}$ & & $\begin{array}{l}-35.0520^{* *} \\
(14.3767)\end{array}$ & & & & $\begin{array}{l}1.2850 \\
(2.7646)\end{array}$ & & $\begin{array}{l}-31.6584^{* *} \\
(13.5071)\end{array}$ \\
\hline OECD dum $m_{j}$ & & & & & & & & & & & & \\
\hline FDI RI Tertiary & & & & $\begin{array}{l}5.5254^{*} \\
(3.1115)\end{array}$ & & $\begin{array}{l}14.6667 \\
(10.6817)\end{array}$ & & & & $\begin{array}{l}-0.2923 \\
(3.0882)\end{array}$ & & $\begin{array}{l}12.6691 \\
(10.7487)\end{array}$ \\
\hline OECD dum & & & $\begin{array}{l}1.4975^{* * *} \\
(0.4943)\end{array}$ & $\begin{array}{l}1.2408^{* *} \\
(0.4877)\end{array}$ & $\begin{array}{l}1.0291^{*} \\
(0.5762)\end{array}$ & $\begin{array}{l}0.7246 \\
(0.4855)\end{array}$ & & & $\begin{array}{l}1.0888 \\
(1.2144)\end{array}$ & $\begin{array}{l}0.5874 \\
(0.9019)\end{array}$ & $\begin{array}{l}1.5750 \\
(1.5839)\end{array}$ & $\begin{array}{l}0.3426 \\
(0.6826)\end{array}$ \\
\hline$R^{2}$ & 0.7646 & 0.7655 & 0.7672 & 0.7687 & 0.7740 & 0.7756 & 0.9522 & 0.9523 & 0.8324 & 0.8365 & 0.8436 & 0.8448 \\
\hline Observations & 6161 & 6161 & 9355 & 9355 & 7568 & 7568 & 6230 & 6230 & 9445 & 9445 & 7645 & 7645 \\
\hline
\end{tabular}

Notes: The dependent variable is bilateral FDI stocks. Columns (1), (2), (3), (4), (5), and (6) represent the results of restrictive measures' impact in the period 2010-2104 and the other columns indicate the effects in 2015-2019. For space reasons, the results of the other control variables are omitted and the estimations include both country and time fixed effects. Standard errors are reported in parentheses and clustered by countrypair level. ${ }^{*}, * * * *$ denote signicance respectively at the $10 \%, 5 \%$ and $1 \%$ levels. 
Table 6: Gravity Estimation Results of Impacts of Restrictive Measures on FDI Stocks: OECD vs. BRICS and others Emerging Countries

\begin{tabular}{|c|c|c|c|c|c|c|c|c|}
\hline \multirow[b]{3}{*}{ Model } & \multicolumn{4}{|c|}{ BRICS countries } & \multicolumn{4}{|c|}{ Emerging excluding BRICS } \\
\hline & \multicolumn{2}{|c|}{ FDI RI global } & \multicolumn{2}{|c|}{ Sectoral FDI RI } & \multicolumn{2}{|c|}{ FDI RI global } & \multicolumn{2}{|c|}{ Sectoral FDI RI } \\
\hline & $(1)$ & (2) & (3) & (4) & (5) & (6) & (7) & (8) \\
\hline FDIRI Global ${ }_{j, t-1}$ & $\begin{array}{l}0.0643 \\
(1.5592)\end{array}$ & $\begin{array}{l}-3.6988^{* * *} \\
(1.0036)\end{array}$ & & & $\begin{array}{l}4.1624 \\
(3.7510)\end{array}$ & $\begin{array}{l}-0.5836 \\
(1.4247)\end{array}$ & & \\
\hline FDI RI Primary ${ }_{j, t-1}$ & & & $\begin{array}{l}1.8398 \\
(2.3826)\end{array}$ & $\begin{array}{l}2.9083 \\
(1.7918)\end{array}$ & & & $\begin{array}{l}0.9789 \\
(8.3325)\end{array}$ & $\begin{array}{l}2.0527 \\
(2.4692)\end{array}$ \\
\hline FDI RI Secondary ${ }_{j, t-1}$ & & & $\begin{array}{l}-1.3180 \\
(2.9618)\end{array}$ & $\begin{array}{l}4.2798^{* *} \\
(1.9205)\end{array}$ & & & $\begin{array}{l}28.6969 \\
(21.3504)\end{array}$ & $\begin{array}{l}8.8480 \\
(8.0209)\end{array}$ \\
\hline FDI RI Tertiary ${ }_{j, t-1}$ & & & $\begin{array}{l}-0.5023 \\
(4.5422)\end{array}$ & $\begin{array}{l}-8.7256^{* * *} \\
(2.6022)\end{array}$ & & & $\begin{array}{l}-7.2014^{* *} \\
(3.6155)\end{array}$ & $\begin{array}{l}-5.6583 \\
(3.5065)\end{array}$ \\
\hline 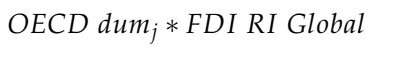 & $\begin{array}{l}-2.2348 \\
(2.7489)\end{array}$ & $\begin{array}{l}2.5939 \\
(1.9748)\end{array}$ & & & $\begin{array}{l}-6.3781 \\
(3.9922)\end{array}$ & $\begin{array}{l}-1.0063 \\
(2.3426)\end{array}$ & & \\
\hline 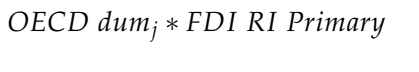 & & & $\begin{array}{l}0.2945 \\
(3.1266)\end{array}$ & $\begin{array}{l}-1.3183 \\
(1.9792)\end{array}$ & & & $\begin{array}{l}1.9154 \\
(8.5453)\end{array}$ & $\begin{array}{l}-0.3630 \\
(2.6292)\end{array}$ \\
\hline OECD dum $_{j}$ FDI RI Secondary & & & $\begin{array}{l}2.6654 \\
(3.8246)\end{array}$ & $\begin{array}{l}-4.0174 \\
(2.8371)\end{array}$ & & & $\begin{array}{l}-28.6064 \\
(21.1684)\end{array}$ & $\begin{array}{l}-8.8681 \\
(8.3190)\end{array}$ \\
\hline OECD dum $_{j}$ FDI RI Tertiary & & & $\begin{array}{l}-4.6841 \\
(5.4679) \\
\end{array}$ & $\begin{array}{l}5.3995 \\
(3.4629)\end{array}$ & & & $\begin{array}{l}2.0828 \\
(4.2043)\end{array}$ & $\begin{array}{l}1.9990 \\
(4.2348)\end{array}$ \\
\hline OECD dum & $\begin{array}{l}-1.5258^{* * *} \\
(0.4154)\end{array}$ & $\begin{array}{l}1.1180^{*} \\
(0.6439)\end{array}$ & $\begin{array}{l}-1.2906^{* * *} \\
(0.3991)\end{array}$ & $\begin{array}{l}0.6786 \\
(0.5045)\end{array}$ & $\begin{array}{l}0.6778 \\
(0.5587)\end{array}$ & $\begin{array}{l}2.7841^{* * *} \\
(0.8244)\end{array}$ & $\begin{array}{l}0.4047 \\
(0.5338)\end{array}$ & $\begin{array}{l}2.4006^{\text {*** }} \\
(0.7038)\end{array}$ \\
\hline $\operatorname{Ln} F D I_{i j, t-1}$ & $\begin{array}{l}0.0992 \\
(0.0724)\end{array}$ & $\begin{array}{l}0.1003^{* *} \\
(0.0479)\end{array}$ & $\begin{array}{l}0.0871 \\
(0.0741)\end{array}$ & $\begin{array}{l}0.0979 * * \\
(0.0452)\end{array}$ & $\begin{array}{l}0.0945 \\
(0.0762)\end{array}$ & $\begin{array}{l}0.0955^{*} \\
(0.0490)\end{array}$ & $\begin{array}{l}0.0761 \\
(0.0779)\end{array}$ & $\begin{array}{l}0.0941^{* *} \\
(0.0461)\end{array}$ \\
\hline Ln distance dij,t-1 $_{1}$ & $\begin{array}{l}-1.9008^{* * *} \\
(0.2753)\end{array}$ & $\begin{array}{l}-1.1124^{* * *} \\
(0.1413)\end{array}$ & $\begin{array}{l}-1.9283^{* * *} \\
(0.2816)\end{array}$ & $\begin{array}{l}-1.1421^{* * *} \\
(0.1543)\end{array}$ & $\begin{array}{l}-1.9148^{* * *} \\
(0.2918)\end{array}$ & $\begin{array}{l}-1.1058^{* * *} \\
(0.1519)\end{array}$ & $\begin{array}{l}-1.9452^{* * *} \\
(0.2962)\end{array}$ & $\begin{array}{l}-1.1328^{* * *} \\
(0.1683)\end{array}$ \\
\hline Common border ${ }_{i j, t-1}$ & $\begin{array}{c}-0.4804^{*} \\
(0.2778)\end{array}$ & $\begin{array}{l}-0.4245^{* * *} \\
(0.1530)\end{array}$ & $\begin{array}{l}-0.4516 \\
(0.2864)\end{array}$ & $\begin{array}{l}-0.3922^{* * *} \\
(0.1472)\end{array}$ & $\begin{array}{l}-0.4263 \\
(0.2881)\end{array}$ & $\begin{array}{l}-0.4216^{* * *} \\
(0.1590)\end{array}$ & $\begin{array}{l}-0.3842 \\
(0.2989)\end{array}$ & $\begin{array}{l}-0.3759^{* *} \\
(0.1515)\end{array}$ \\
\hline Common $\operatorname{lang}_{i j, t-1}$ & $\begin{array}{l}0.5240^{*} \\
(0.2721)\end{array}$ & $\begin{array}{l}0.2685^{*} \\
(0.1515)\end{array}$ & $\begin{array}{l}0.5160^{*} \\
(0.2718)\end{array}$ & $\begin{array}{l}0.2867^{*} \\
(0.1507)\end{array}$ & $\begin{array}{l}0.5071^{*} \\
(0.2843)\end{array}$ & $\begin{array}{l}0.2776^{*} \\
(0.1528)\end{array}$ & $\begin{array}{l}0.4996^{*} \\
(0.2852)\end{array}$ & $\begin{array}{l}0.2779^{*} \\
(0.1511)\end{array}$ \\
\hline $\begin{array}{l}\text { Colonial links }{ }_{i j, t-1} \\
\text { RTA }_{i j, t-1}\end{array}$ & $\begin{array}{l}0.5421 \\
(0.3455) \\
-0.6561^{* *} \\
(0.2591)\end{array}$ & $\begin{array}{l}0.3781^{* *} \\
(0.1569) \\
0.3362^{* *} \\
(0.1495)\end{array}$ & $\begin{array}{l}0.4658 \\
(0.3544) \\
-0.7011^{* * *} \\
(0.2688)\end{array}$ & $\begin{array}{l}0.3217^{* *} \\
(0.1523) \\
0.3249^{* *} \\
(0.1650)\end{array}$ & $\begin{array}{l}0.5796 \\
(0.3552) \\
-0.7178^{* *} \\
(0.2830)\end{array}$ & $\begin{array}{l}0.3791^{* *} \\
(0.1592) \\
0.3958^{* *} \\
(0.1618)\end{array}$ & $\begin{array}{l}0.4821 \\
(0.3625) \\
-0.7604^{* * *} \\
(0.2911)\end{array}$ & $\begin{array}{l}0.3153^{* *} \\
(0.1535) \\
0.3923^{* *} \\
(0.1795)\end{array}$ \\
\hline$B I T_{i j, t-1}$ & $\begin{array}{l}-0.7016^{* * *} \\
(0.1722)\end{array}$ & $\begin{array}{l}-0.3301^{*} \\
(0.1831)\end{array}$ & $\begin{array}{l}-0.7481^{* * *} \\
(0.1699)\end{array}$ & $\begin{array}{l}-0.4597^{* *} \\
(0.1978)\end{array}$ & $\begin{array}{l}-0.7425^{* * *} \\
(0.1825)\end{array}$ & $\begin{array}{c}-0.3570^{*} \\
(0.2012)\end{array}$ & $\begin{array}{l}-0.8080^{* * *} \\
(0.1809)\end{array}$ & $\begin{array}{l}-0.5139^{* *} \\
(0.2204)\end{array}$ \\
\hline $\operatorname{Ln} G D P_{i, t-1}$ & $\begin{array}{l}0.8474^{* * *} \\
(0.2334)\end{array}$ & $\begin{array}{l}-0.0899 \\
(0.0837)\end{array}$ & $\begin{array}{l}0.8368^{* * *} \\
(0.2319)\end{array}$ & $\begin{array}{l}-0.0771 \\
(0.0794)\end{array}$ & $\begin{array}{l}0.7964^{* * *} \\
(0.2658)\end{array}$ & $\begin{array}{l}-0.1296 \\
(0.0933)\end{array}$ & $\begin{array}{l}0.7860^{* * *} \\
(0.2514)\end{array}$ & $\begin{array}{l}-0.0814 \\
(0.0885)\end{array}$ \\
\hline $\operatorname{Ln} G D P_{j, t-1}$ & $\begin{array}{l}2.0854^{* * *} \\
(0.1824)\end{array}$ & $\begin{array}{l}2.4323^{* * *} \\
(0.1325)\end{array}$ & $\begin{array}{l}1.9580^{* * *} \\
(0.1820)\end{array}$ & $\begin{array}{l}2.2805^{* * *} \\
(0.1338)\end{array}$ & $\begin{array}{l}1.9212^{* * *} \\
(0.1766)\end{array}$ & $\begin{array}{l}2.4128^{* * *} \\
(0.1402)\end{array}$ & $\begin{array}{l}1.7696^{* * *} \\
(0.1713)\end{array}$ & $\begin{array}{l}2.2578^{* * *} \\
(0.1418)\end{array}$ \\
\hline Trade openness $_{j, t-1}$ & $\begin{array}{l}1.2512^{* * *} \\
(0.1780)\end{array}$ & $\begin{array}{l}1.4381^{* * *} \\
(0.1160)\end{array}$ & $\begin{array}{l}1.2087^{* * *} \\
(0.1788)\end{array}$ & $\begin{array}{l}1.3695^{* * *} \\
(0.1142)\end{array}$ & $\begin{array}{l}1.1718^{* * *} \\
(0.1802)\end{array}$ & $\begin{array}{l}1.4125^{* * *} \\
(0.1187)\end{array}$ & $\begin{array}{l}1.1625^{* * *} \\
(0.1845)\end{array}$ & $\begin{array}{l}1.3610^{* * *} \\
(0.1136)\end{array}$ \\
\hline Regulatory quality $_{j, t-1}$ & $\begin{array}{l}0.2356^{* *} \\
(0.0957)\end{array}$ & $\begin{array}{l}0.1869^{* * *} \\
(0.0673)\end{array}$ & $\begin{array}{l}0.2121^{* *} \\
(0.0914)\end{array}$ & $\begin{array}{l}0.1733^{* * *} \\
(0.0647)\end{array}$ & $\begin{array}{l}0.2152^{* *} \\
(0.0967)\end{array}$ & $\begin{array}{l}0.1597^{* *} \\
(0.0661)\end{array}$ & $\begin{array}{l}0.2188^{* *} \\
(0.0924)\end{array}$ & $\begin{array}{l}0.1599 * * \\
(0.0637)\end{array}$ \\
\hline Ln productivity pr,t-1 $_{1}$ & $\begin{array}{l}-0.5885^{* * *} \\
(0.2093)\end{array}$ & $\begin{array}{l}0.6638^{* * *} \\
(0.2233)\end{array}$ & $\begin{array}{l}-0.5925^{* *} \\
(0.2904)\end{array}$ & $\begin{array}{l}0.6601^{* * *} \\
(0.1875)\end{array}$ & $\begin{array}{l}-0.5148 \\
(0.3685)\end{array}$ & $\begin{array}{l}0.8445^{* * *} \\
(0.3029)\end{array}$ & $\begin{array}{l}-0.7243 \\
(0.4934)\end{array}$ & $\begin{array}{l}0.7039^{* *} \\
(0.2760)\end{array}$ \\
\hline Ln tax burden $_{j, t-1}$ & $\begin{array}{l}-1.4698 \\
(0.9033)\end{array}$ & $\begin{array}{l}-0.2544 \\
(0.6799)\end{array}$ & $\begin{array}{l}-0.8940 \\
(0.9463)\end{array}$ & $\begin{array}{l}0.1406 \\
(0.6715)\end{array}$ & $\begin{array}{l}-1.0732 \\
(0.9222)\end{array}$ & $\begin{array}{l}-0.0828 \\
(0.7308)\end{array}$ & $\begin{array}{l}-0.6601 \\
(0.9579)\end{array}$ & $\begin{array}{l}0.1601 \\
(0.7126)\end{array}$ \\
\hline$H C D_{i j, t-1}$ & $\begin{array}{l}-6.1903^{* * *} \\
(1.0716)\end{array}$ & $\begin{array}{l}-0.4411 \\
(1.2010)\end{array}$ & $\begin{array}{l}-6.3859^{* * *} \\
(1.0858)\end{array}$ & $\begin{array}{l}-0.4920 \\
(1.2232)\end{array}$ & $\begin{array}{l}-7.1014^{* * *} \\
(1.2259)\end{array}$ & $\begin{array}{l}0.0522 \\
(1.4662)\end{array}$ & $\begin{array}{l}-7.2965^{* * *} \\
(1.2285)\end{array}$ & $\begin{array}{l}-0.4484 \\
(1.4856)\end{array}$ \\
\hline Ln Labor freedom $_{j, t-1}$ & $\begin{array}{l}2.0855^{* * *} \\
(0.6565)\end{array}$ & $\begin{array}{l}2.5584^{* * *} \\
(0.5395)\end{array}$ & $\begin{array}{l}2.1380^{* * *} \\
(0.6784)\end{array}$ & $\begin{array}{l}2.5483^{* * *} \\
(0.5431)\end{array}$ & $\begin{array}{l}2.1289^{* * *} \\
(0.6574)\end{array}$ & $\begin{array}{l}2.6242^{* * *} \\
(0.5673)\end{array}$ & $\begin{array}{l}2.3356^{* * *} \\
(0.6896)\end{array}$ & $\begin{array}{l}2.6650^{* * *} \\
(0.5693)\end{array}$ \\
\hline $\begin{array}{l}\text { Time - FE } \\
\text { Country - FE }\end{array}$ & $\begin{array}{l}\text { Yes } \\
\text { No }\end{array}$ & $\begin{array}{l}\text { Yes } \\
\text { Yes }\end{array}$ & $\begin{array}{l}\text { Yes } \\
\text { No }\end{array}$ & $\begin{array}{l}\text { Yes } \\
\text { Yes }\end{array}$ & $\begin{array}{l}\text { Yes } \\
\text { No }\end{array}$ & $\begin{array}{l}\text { Yes } \\
\text { Yes }\end{array}$ & $\begin{array}{l}\text { Yes } \\
\text { No }\end{array}$ & $\begin{array}{l}\text { Yes } \\
\text { Yes }\end{array}$ \\
\hline $\begin{array}{l}R^{2} \\
\text { Observations }\end{array}$ & $\begin{array}{l}0.5141 \\
16627 \\
\end{array}$ & $\begin{array}{l}0.7938 \\
16627\end{array}$ & $\begin{array}{l}0.5183 \\
16627 \\
\end{array}$ & $\begin{array}{l}0.7967 \\
16627\end{array}$ & $\begin{array}{l}0.5269 \\
16275 \\
\end{array}$ & $\begin{array}{l}0.8041 \\
16275\end{array}$ & $\begin{array}{l}0.5333 \\
16275\end{array}$ & $\begin{array}{l}0.8065 \\
16275\end{array}$ \\
\hline
\end{tabular}


Table 7: OECD outward and inward FDI by service sector (\% of service FDI)

\begin{tabular}{l|llllll}
\hline \hline & Years & 2015 & 2016 & 2017 & 2018 & 2019 \\
\hline $\begin{array}{l}\text { Financial } \\
\text { and insurance } \\
\text { activities }\end{array}$ & Inward & 60.57 & 62.2 & 62.04 & 55.07 & 59.57 \\
\hline $\begin{array}{l}\text { Wholesale and retail } \\
\text { trade repair of motor } \\
\text { vehicles and motorcycles }\end{array}$ & Outward & 65.44 & 65.71 & 66.87 & 65.19 & 68.25 \\
\hline $\begin{array}{l}\text { Transportation } \\
\text { and storage }\end{array}$ & Outward & 11.89 & 11.49 & 13.79 & 12.57 & 13.6 \\
& Inward & 2.25 & 8.94 & 8.56 & 9.03 & 7.83 \\
\hline \hline
\end{tabular}

Source: Author's calculation based on OECD FDI data 
Table 8: The Impact of FDI Restrictions in the Financial Sector on FDI Stocks: IntraOECD

\begin{tabular}{|c|c|c|c|c|c|c|c|c|}
\hline \multirow{3}{*}{$\begin{array}{l}\text { Specification } \\
\text { Dependant variable } \\
\text { Years } \\
\text { Model }\end{array}$} & \multicolumn{8}{|c|}{$\begin{array}{c}\text { PPML Estimate } \\
\frac{\text { FDI }_{i j, t}}{\text { GDPdeflator }_{i j, t}} \\
\mathbf{2 0 1 0 - 2 0 1 9}\end{array}$} \\
\hline & \multicolumn{4}{|c|}{ Global financial sector } & \multicolumn{4}{|c|}{ Disaggregated financial sector } \\
\hline & $(1)$ & $(2)$ & (3) & $(4)$ & $(5)$ & $(6)$ & $(7)$ & $(8)$ \\
\hline FDIRI Financial ${ }_{j, t-1}$ & $\begin{array}{l}-0.5106 \\
(1.4064)\end{array}$ & $\begin{array}{l}-0.2140 \\
(1.4145)\end{array}$ & $\begin{array}{l}-0.0402 \\
(1.5903)\end{array}$ & $\begin{array}{l}-0.0667 \\
(1.5515)\end{array}$ & & & & \\
\hline FDI RI Banking $g_{j, t-1}$ & & & & & $\begin{array}{l}0.5432 \\
(1.5084)\end{array}$ & $\begin{array}{l}0.2900 \\
(1.5149)\end{array}$ & $\begin{array}{l}5.2978^{* * *} \\
(1.4446)\end{array}$ & $\begin{array}{l}4.9846^{* * *} \\
(1.3903)\end{array}$ \\
\hline FDI RI Insurance $_{j, t-1}$ & & & & & $\begin{array}{l}1.3693 \\
(1.7819)\end{array}$ & $\begin{array}{l}2.0304 \\
(1.6664)\end{array}$ & $\begin{array}{l}-2.1418 \\
(2.2261)\end{array}$ & $\begin{array}{l}-1.8860 \\
(2.1842)\end{array}$ \\
\hline FDI RI Other finance fit,-1 & & & & & $\begin{array}{l}-1.9266^{*} \\
(1.1159)\end{array}$ & $\begin{array}{l}-1.8297^{*} \\
(1.0111)\end{array}$ & $\begin{array}{l}-5.8821^{* * *} \\
(1.4426)\end{array}$ & $\begin{array}{l}-5.6653^{* * *} \\
(1.3660)\end{array}$ \\
\hline FDI RI Business services ${ }_{j, t-1}$ & & & & & $\begin{array}{l}-1.4061^{\text {*** }} \\
(0.5220)\end{array}$ & $\begin{array}{l}-1.2451^{* *} \\
(0.4949)\end{array}$ & $\begin{array}{l}-2.6909^{* * *} \\
(0.7163)\end{array}$ & $\begin{array}{l}-2.4932^{* * *} \\
(0.7058)\end{array}$ \\
\hline $\operatorname{Ln} F D I_{i j, t-1}$ & $\begin{array}{l}1.3941^{* * *} \\
(0.0608)\end{array}$ & $\begin{array}{l}1.4429^{* * *} \\
(0.0632)\end{array}$ & $\begin{array}{l}0.6669^{* * *} \\
(0.0623)\end{array}$ & $\begin{array}{l}0.7428^{* * *} \\
(0.0641)\end{array}$ & $\begin{array}{l}1.3746^{* * *} \\
(0.0586)\end{array}$ & $\begin{array}{l}1.4238^{* * *} \\
(0.0621)\end{array}$ & $\begin{array}{l}0.6155^{* * *} \\
(0.0600)\end{array}$ & $\begin{array}{l}0.6797^{* * *} \\
(0.0639)\end{array}$ \\
\hline Ln distance $_{i j, t-1}$ & $\begin{array}{l}-0.7444^{* * *} \\
(0.1468)\end{array}$ & $\begin{array}{l}-0.6897^{* * *} \\
(0.1233)\end{array}$ & $\begin{array}{l}-0.7825^{* * *} \\
(0.1072)\end{array}$ & $\begin{array}{l}-0.7114^{* * *} \\
(0.1047)\end{array}$ & $\begin{array}{l}-0.7823^{* * *} \\
(0.1345)\end{array}$ & $\begin{array}{l}-0.7397^{* * *} \\
(0.1097)\end{array}$ & $\begin{array}{l}-0.8609^{* * *} \\
(0.1200)\end{array}$ & $\begin{array}{l}-0.8068^{* * *} \\
(0.1164)\end{array}$ \\
\hline Common border $r_{i j, t-1}$ & $\begin{array}{l}-0.2543^{* *} \\
(0.1187)\end{array}$ & $\begin{array}{l}-0.2626^{* *} \\
(0.1056)\end{array}$ & $\begin{array}{l}-0.2819^{* *} \\
(0.1141)\end{array}$ & $\begin{array}{l}-0.2707^{* *} \\
(0.1092)\end{array}$ & $\begin{array}{c}-0.2109^{*} \\
(0.1173)\end{array}$ & $\begin{array}{l}-0.2232^{* *} \\
(0.1038)\end{array}$ & $\begin{array}{c}-0.2030^{*} \\
(0.1157)\end{array}$ & $\begin{array}{l}-0.1996^{*} \\
(0.1130)\end{array}$ \\
\hline Common lang $_{i j, t-1}$ & $\begin{array}{l}0.1098 \\
(0.1180)\end{array}$ & $\begin{array}{l}0.0793 \\
(0.1115)\end{array}$ & $\begin{array}{l}0.1088 \\
(0.1109)\end{array}$ & $\begin{array}{l}0.0989 \\
(0.1049)\end{array}$ & $\begin{array}{l}0.1156 \\
(0.1161)\end{array}$ & $\begin{array}{l}0.0793 \\
(0.1081)\end{array}$ & $\begin{array}{l}0.1527 \\
(0.1127)\end{array}$ & $\begin{array}{l}0.1380 \\
(0.1082)\end{array}$ \\
\hline Colonial links $s_{i j, t-1}$ & $\begin{array}{l}0.0846 \\
(0.1764)\end{array}$ & $\begin{array}{l}0.0752 \\
(0.1635)\end{array}$ & $\begin{array}{l}0.2522^{* *} \\
(0.1221)\end{array}$ & $\begin{array}{l}0.2438^{* *} \\
(0.1197)\end{array}$ & $\begin{array}{l}0.0573 \\
(0.1723)\end{array}$ & $\begin{array}{l}0.0475 \\
(0.1600)\end{array}$ & $\begin{array}{l}0.1931^{*} \\
(0.1155)\end{array}$ & $\begin{array}{l}0.1888^{*} \\
(0.1143)\end{array}$ \\
\hline$R T A_{i j, t-1}$ & $\begin{array}{l}-0.4974^{* * *} \\
(0.1392)\end{array}$ & $\begin{array}{l}-0.4432^{* * *} \\
(0.1379)\end{array}$ & $\begin{array}{l}0.1647 \\
(0.1203)\end{array}$ & $\begin{array}{l}0.2137^{*} \\
(0.1123)\end{array}$ & $\begin{array}{l}-0.5291^{* * *} \\
(0.1374)\end{array}$ & $\begin{array}{l}-0.4747^{* * *} \\
(0.1334)\end{array}$ & $\begin{array}{l}0.1311 \\
(0.1285)\end{array}$ & $\begin{array}{l}0.1687 \\
(0.1211)\end{array}$ \\
\hline$B I T_{i j, t-1}$ & $\begin{array}{l}-0.2043^{*} \\
(0.1124)\end{array}$ & $\begin{array}{l}-0.1899^{*} \\
(0.1064)\end{array}$ & $\begin{array}{l}-0.1643 \\
(0.1534)\end{array}$ & $\begin{array}{l}-0.1503 \\
(0.1454)\end{array}$ & $\begin{array}{l}-0.2381^{* *} \\
(0.1001)\end{array}$ & $\begin{array}{l}-0.2342^{* *} \\
(0.0946)\end{array}$ & $\begin{array}{l}-0.1655 \\
(0.1860)\end{array}$ & $\begin{array}{l}-0.1598 \\
(0.1775)\end{array}$ \\
\hline $\operatorname{Ln} G D P_{i, t-1}$ & $\begin{array}{l}0.2057^{* * *} \\
(0.0267)\end{array}$ & $\begin{array}{l}0.1428 \\
(0.1017)\end{array}$ & $\begin{array}{l}0.2177^{* * *} \\
(0.0255)\end{array}$ & $\begin{array}{l}-0.2773 \\
(0.1867)\end{array}$ & $\begin{array}{l}0.2072^{* * *} \\
(0.0275)\end{array}$ & $\begin{array}{l}0.1494 \\
(0.1064)\end{array}$ & $\begin{array}{l}0.2162^{* * *} \\
(0.0256)\end{array}$ & $\begin{array}{l}-0.2623 \\
(0.1843)\end{array}$ \\
\hline $\operatorname{Ln} G D P_{j, t-1}$ & $\begin{array}{l}0.6205^{* * *} \\
(0.1141)\end{array}$ & $\begin{array}{l}0.6434^{* * *} \\
(0.1095)\end{array}$ & $\begin{array}{l}1.6250^{* * *} \\
(0.1431)\end{array}$ & $\begin{array}{l}1.5791^{* * *} \\
(0.1399)\end{array}$ & $\begin{array}{l}0.4719^{* * *} \\
(0.1046)\end{array}$ & $\begin{array}{l}0.5214^{* * *} \\
(0.0984)\end{array}$ & $\begin{array}{l}1.1968^{* * *} \\
(0.1268)\end{array}$ & $\begin{array}{l}1.1815^{\text {*** }} \\
(0.1252)\end{array}$ \\
\hline Trade openness $s_{j, t-1}$ & $\begin{array}{l}0.3725^{* * *} \\
(0.0917)\end{array}$ & $\begin{array}{l}0.3866^{* * *} \\
(0.0938)\end{array}$ & $\begin{array}{l}0.9617^{* * *} \\
(0.1005)\end{array}$ & $\begin{array}{l}0.9320^{* * *} \\
(0.0988)\end{array}$ & $\begin{array}{l}0.2868^{* * *} \\
(0.0861)\end{array}$ & $\begin{array}{l}0.3086^{* * *} \\
(0.0876)\end{array}$ & $\begin{array}{l}0.7429^{* * *} \\
(0.0924)\end{array}$ & $\begin{array}{l}0.7265^{* * *} \\
(0.0916)\end{array}$ \\
\hline Regulatory quality $y_{j-1}$ & $\begin{array}{l}0.1148^{* * *} \\
(0.0361)\end{array}$ & $\begin{array}{l}0.0529 \\
(0.0403)\end{array}$ & $\begin{array}{l}0.1705^{* * *} \\
(0.0425)\end{array}$ & $\begin{array}{l}0.1157^{* * *} \\
(0.0443)\end{array}$ & $\begin{array}{l}0.0995^{* * *} \\
(0.0368)\end{array}$ & $\begin{array}{l}0.0387 \\
(0.0397)\end{array}$ & $\begin{array}{l}0.1143^{* * *} \\
(0.0378)\end{array}$ & $\begin{array}{l}0.0610 \\
(0.0405)\end{array}$ \\
\hline Ln productivity prt $_{-1}$ & $\begin{array}{l}0.0505 \\
(0.5397)\end{array}$ & $\begin{array}{l}0.2934 \\
(0.5372)\end{array}$ & $\begin{array}{l}0.7395^{*} \\
(0.4165)\end{array}$ & $\begin{array}{l}0.8965^{* *} \\
(0.4096)\end{array}$ & $\begin{array}{l}0.1869 \\
(0.5504)\end{array}$ & $\begin{array}{l}0.4409 \\
(0.5389)\end{array}$ & $\begin{array}{l}0.9066^{* *} \\
(0.4369)\end{array}$ & $\begin{array}{l}1.0488^{* *} \\
(0.4262)\end{array}$ \\
\hline Ln tax burden ${ }_{j, t-1}$ & $\begin{array}{l}-0.0927 \\
(0.6541)\end{array}$ & $\begin{array}{l}0.0213 \\
(0.6232)\end{array}$ & $\begin{array}{l}-0.1190 \\
(0.6335)\end{array}$ & $\begin{array}{l}-0.0018 \\
(0.6250)\end{array}$ & $\begin{array}{l}-0.5972 \\
(0.8737)\end{array}$ & $\begin{array}{l}-0.3109 \\
(0.8334)\end{array}$ & $\begin{array}{l}-1.6285^{* *} \\
(0.8286)\end{array}$ & $\begin{array}{c}-1.3788^{*} \\
(0.8336)\end{array}$ \\
\hline$H C D_{i j, t-1}$ & $\begin{array}{l}-0.9563 \\
(0.9467)\end{array}$ & $\begin{array}{c}-1.6821^{*} \\
(0.9099)\end{array}$ & $\begin{array}{l}0.3661 \\
(1.2280)\end{array}$ & $\begin{array}{l}0.0255 \\
(1.1694)\end{array}$ & $\begin{array}{l}-1.0666 \\
(0.9583)\end{array}$ & $\begin{array}{l}-1.8185^{* *} \\
(0.9254)\end{array}$ & $\begin{array}{l}0.2139 \\
(1.3182)\end{array}$ & $\begin{array}{l}-0.1305 \\
(1.2719)\end{array}$ \\
\hline Ln Labor freedom frt $_{j, 1}$ & $\begin{array}{l}0.6489^{*} \\
(0.3857)\end{array}$ & $\begin{array}{l}0.5062 \\
(0.3144)\end{array}$ & $\begin{array}{l}1.8040^{* * *} \\
(0.4476)\end{array}$ & $\begin{array}{l}1.6772^{* * *} \\
(0.4324)\end{array}$ & $\begin{array}{l}0.8444^{*} \\
(0.4975)\end{array}$ & $\begin{array}{l}0.6977^{*} \\
(0.4198)\end{array}$ & $\begin{array}{l}1.8467^{* * *} \\
(0.5470)\end{array}$ & $\begin{array}{l}1.7227^{* * *} \\
(0.5369)\end{array}$ \\
\hline Time - FE & No & Yes & $\begin{array}{l}\text { No } \\
\text { Yes }\end{array}$ & Yes & No & Yes & No & Yes \\
\hline$R^{2}$ & 0.7643 & $\begin{array}{l}\text { No } \\
0.7742\end{array}$ & $\begin{array}{l}\text { Yes } \\
0.8326\end{array}$ & $\begin{array}{l}\text { Yes } \\
0.8368\end{array}$ & 0.7663 & 0.7760 & $\begin{array}{l}\text { res } \\
0.8398\end{array}$ & $\begin{array}{l}\text { Yes } \\
0.8431\end{array}$ \\
\hline Observations & 12391 & 12391 & 12391 & 12391 & 12391 & 12391 & 12391 & 12391 \\
\hline
\end{tabular}


Table 9: Exports of Primary and Manufacturing Goods from 2015-2019

\begin{tabular}{l|lll}
\hline \hline Countries & Years & $\begin{array}{l}\text { Primary commodities } \\
\text { precious stones and } \\
\text { non-monetary gold }\end{array}$ & $\begin{array}{l}\text { Manufactued } \\
\text { goods }\end{array}$ \\
\hline Africa & 2015 & $5,68 \mathrm{E}+04$ & $2,77 \mathrm{E}+04$ \\
Emerging & 2015 & $1,32 \mathrm{E}+06$ & $9,07 \mathrm{E}+05$ \\
\hline Africa & 2016 & $5,56 \mathrm{E}+04$ & $2,77 \mathrm{E}+04$ \\
Emerging & 2016 & $1,26 \mathrm{E}+06$ & $8,46 \mathrm{E}+05$ \\
\hline Africa & 2017 & $6,58 \mathrm{E}+04$ & $2,91 \mathrm{E}+04$ \\
Emerging & 2017 & $1,48 \mathrm{E}+06$ & $9,23 \mathrm{E}+05$ \\
\hline Africa & 2018 & $6,82 \mathrm{E}+04$ & $3,19 \mathrm{E}+04$ \\
Emerging & 2018 & $1,60 \mathrm{E}+06$ & $9,89 \mathrm{E}+05$ \\
\hline Africa & 2019 & $6,57 \mathrm{E}+04$ & $2,93 \mathrm{E}+04$ \\
Emerging & 2019 & $1,49 \mathrm{E}+06$ & $9,83 \mathrm{E}+05$ \\
\hline \hline
\end{tabular}

Africa includes North and South African countries. Emerging countries include Central and South Asia, Eastern and South-Eastern Asia and Latin America

Source: Author's calculation based on UNCTAD data 
Table 10: The Impact of FDI Restrictive Measures in the Agricultural and Manufacturing Sectors on FDI Stocks: OECD vs. Emerging Countries

\begin{tabular}{|c|c|c|c|c|c|c|c|c|}
\hline \multirow{2}{*}{$\begin{array}{l}\text { Specification } \\
\text { Dependant variable } \\
\text { Years } \\
\text { Model }\end{array}$} & \multirow{2}{*}{\multicolumn{8}{|c|}{$\begin{array}{c}\text { PPML Estimate } \\
\frac{F D I_{i j, t}}{\text { GDPdeflator }_{i, j, t}} \\
\mathbf{2 0 1 0 - 2 0 1 9}\end{array}$}} \\
\hline & & & & & & & & \\
\hline $\begin{array}{l}\text { Model } \\
\text { FDI RI Agriculture }{ }_{j, t-1}\end{array}$ & $\begin{array}{l}(1) \\
0.5197 \\
(0.6648)\end{array}$ & $\begin{array}{l}(2) \\
0.8793 \\
(0.7391)\end{array}$ & $\begin{array}{l}(3) \\
-0.1722 \\
(0.6100)\end{array}$ & $\begin{array}{l}(4) \\
-0.6223 \\
(0.6176)\end{array}$ & $\begin{array}{l}(5) \\
1.1153 \\
(0.8349)\end{array}$ & $\begin{array}{l}(6) \\
1.9881^{* *} \\
(0.9649)\end{array}$ & $\begin{array}{l}(7) \\
0.2157 \\
(0.8271)\end{array}$ & $\begin{array}{l}(8) \\
0.2306 \\
(0.8243)\end{array}$ \\
\hline FDI RI Manufacturing ${ }_{j, t-1}$ & $\begin{array}{l}-1.7103 \\
(1.9333)\end{array}$ & $\begin{array}{l}-0.9988 \\
(2.0439)\end{array}$ & $\begin{array}{l}-2.5898^{*} \\
(1.3222)\end{array}$ & $\begin{array}{l}-2.7588^{* *} \\
(1.3264)\end{array}$ & $\begin{array}{l}-3.4662 \\
(2.3242)\end{array}$ & $\begin{array}{l}-1.5959 \\
(2.2909)\end{array}$ & $\begin{array}{l}-4.8008^{* * *} \\
(1.5543)\end{array}$ & $\begin{array}{l}-4.8333^{* * *} \\
(1.6202)\end{array}$ \\
\hline OECD dum ${ }_{j} *$ FDI RI Agriculture & $\begin{array}{l}-0.9399 \\
(1.3006)\end{array}$ & $\begin{array}{l}-1.4405 \\
(1.3662)\end{array}$ & $\begin{array}{l}-1.2059 \\
(0.9178)\end{array}$ & $\begin{array}{l}-0.5464 \\
(0.9725)\end{array}$ & $\begin{array}{l}-1.4877 \\
(1.4050)\end{array}$ & $\begin{array}{l}-2.9163^{*} \\
(1.5840)\end{array}$ & $\begin{array}{l}-1.5352 \\
(1.0672)\end{array}$ & $\begin{array}{l}-1.3641 \\
(1.0940)\end{array}$ \\
\hline OECD dum ${ }_{j} *$ FDI RI Manufacturing & $\begin{array}{l}3.5029 \\
(3.3960)\end{array}$ & $\begin{array}{l}2.3922 \\
(3.4249)\end{array}$ & $\begin{array}{l}2.9871 \\
(2.1544)\end{array}$ & $\begin{array}{l}3.8300^{*} \\
(2.1974)\end{array}$ & $\begin{array}{l}5.2172 \\
(3.6057)\end{array}$ & $\begin{array}{l}2.6126 \\
(3.5207)\end{array}$ & $\begin{array}{l}5.2991^{* *} \\
(2.2957)\end{array}$ & $\begin{array}{l}5.7823^{* *} \\
(2.3892)\end{array}$ \\
\hline$O E C D d u m_{j}$ & $\begin{array}{l}-0.3915 \\
(0.3540)\end{array}$ & $\begin{array}{l}-0.5786^{*} \\
(0.3421)\end{array}$ & $\begin{array}{l}0.5501^{* *} \\
(0.2419)\end{array}$ & $\begin{array}{l}2.1064^{* * *} \\
(0.6114)\end{array}$ & $\begin{array}{l}-0.4175 \\
(0.3527)\end{array}$ & $\begin{array}{l}-1.6086^{* * *} \\
(0.3982)\end{array}$ & $\begin{array}{l}0.1650 \\
(0.2385)\end{array}$ & $\begin{array}{l}1.8455^{* *} \\
(0.8667)\end{array}$ \\
\hline$L n F D I_{i j, t-1}$ & $\begin{array}{l}0.1807^{* * *} \\
(0.0644)\end{array}$ & $\begin{array}{l}0.1214 \\
(0.0745)\end{array}$ & $\begin{array}{l}0.2175^{* * *} \\
(0.0454)\end{array}$ & $\begin{array}{l}0.1026^{* *} \\
(0.0488)\end{array}$ & $\begin{array}{l}0.1667^{* * *} \\
(0.0642)\end{array}$ & $\begin{array}{l}0.1039 \\
(0.0741)\end{array}$ & $\begin{array}{l}0.2051^{* * *} \\
(0.0448)\end{array}$ & $\begin{array}{l}0.1018^{* *} \\
(0.0486)\end{array}$ \\
\hline Ln distance $_{i j, t-1}$ & $\begin{array}{l}-1.9593^{* * *} \\
(0.2646)\end{array}$ & $\begin{array}{l}-1.9546^{* * *} \\
(0.2688)\end{array}$ & $\begin{array}{l}-1.0663^{* * *} \\
(0.1383)\end{array}$ & $\begin{array}{l}-1.0953^{* * *} \\
(0.1402)\end{array}$ & $\begin{array}{l}-1.9180^{* * *} \\
(0.2732)\end{array}$ & $\begin{array}{l}-1.9208^{* * *} \\
(0.2790)\end{array}$ & $\begin{array}{l}-1.0580^{* * *} \\
(0.1407)\end{array}$ & $\begin{array}{l}-1.0837^{* * *} \\
(0.1436)\end{array}$ \\
\hline Common border $r_{i j, t-1}$ & $\begin{array}{l}-0.5461^{*} \\
(0.2790)\end{array}$ & $\begin{array}{l}-0.5182^{*} \\
(0.2785)\end{array}$ & $\begin{array}{l}-0.4234^{* * *} \\
(0.1573)\end{array}$ & $\begin{array}{l}-0.4494^{* * *} \\
(0.1584)\end{array}$ & $\begin{array}{l}-0.5201^{*} \\
(0.2798)\end{array}$ & $\begin{array}{l}-0.5043^{*} \\
(0.2804)\end{array}$ & $\begin{array}{l}-0.4192^{* * *} \\
(0.1594)\end{array}$ & $\begin{array}{l}-0.4303^{* * *} \\
(0.1600)\end{array}$ \\
\hline Common lang $i j, t-1$ & $\begin{array}{l}0.4760^{*} \\
(0.2802)\end{array}$ & $\begin{array}{l}0.4889^{*} \\
(0.2805)\end{array}$ & $\begin{array}{l}0.2905^{*} \\
(0.1536)\end{array}$ & $\begin{array}{l}0.2638^{*} \\
(0.1542)\end{array}$ & $\begin{array}{l}0.4652^{*} \\
(0.2799)\end{array}$ & $\begin{array}{l}0.4938^{*} \\
(0.2811)\end{array}$ & $\begin{array}{l}0.2723^{*} \\
(0.1547)\end{array}$ & $\begin{array}{l}0.2433 \\
(0.1556)\end{array}$ \\
\hline Colonial links $s_{i j, t-1}$ & $\begin{array}{l}0.6308^{*} \\
(0.3474)\end{array}$ & $\begin{array}{l}0.6007^{*} \\
(0.3506)\end{array}$ & $\begin{array}{l}0.4069^{* * *} \\
(0.1514)\end{array}$ & $\begin{array}{l}0.4085^{* * *} \\
(0.1527)\end{array}$ & $\begin{array}{l}0.6041^{*} \\
(0.3505)\end{array}$ & $\begin{array}{l}0.5666 \\
(0.3526)\end{array}$ & $\begin{array}{l}0.4019^{* * *} \\
(0.1521)\end{array}$ & $\begin{array}{l}0.4067^{* * *} \\
(0.1525)\end{array}$ \\
\hline$R T A_{i j, t-1}$ & $\begin{array}{l}-0.6103^{* *} \\
(0.2523)\end{array}$ & $\begin{array}{l}-0.6306^{* *} \\
(0.2540)\end{array}$ & $\begin{array}{l}0.3817^{* * *} \\
(0.1413)\end{array}$ & $\begin{array}{l}0.3511^{* *} \\
(0.1468)\end{array}$ & $\begin{array}{l}-0.6441^{* *} \\
(0.2610)\end{array}$ & $\begin{array}{l}-0.6491^{* *} \\
(0.2613)\end{array}$ & $\begin{array}{l}0.3780^{* * *} \\
(0.1451)\end{array}$ & $\begin{array}{l}0.3439^{* *} \\
(0.1510)\end{array}$ \\
\hline$B I T_{i j, t-1}$ & $\begin{array}{l}-0.6762^{* * *} \\
(0.1701)\end{array}$ & $\begin{array}{l}-0.6871^{* * *} \\
(0.1683)\end{array}$ & $\begin{array}{l}-0.3457^{* *} \\
(0.1677)\end{array}$ & $\begin{array}{l}-0.3075^{*} \\
(0.1697)\end{array}$ & $\begin{array}{l}-0.6454^{* * *} \\
(0.1742)\end{array}$ & $\begin{array}{l}-0.6676^{* * *} \\
(0.1730)\end{array}$ & $\begin{array}{l}-0.3193^{*} \\
(0.1731)\end{array}$ & $\begin{array}{l}-0.2900^{*} \\
(0.1748)\end{array}$ \\
\hline Ln GDP $P_{i, t-1}$ & $\begin{array}{l}0.8340^{* * *} \\
(0.2573)\end{array}$ & $\begin{array}{l}0.8367^{* * *} \\
(0.2553)\end{array}$ & $\begin{array}{l}0.1939^{* * *} \\
(0.0291)\end{array}$ & $\begin{array}{l}-0.1300^{*} \\
(0.0734)\end{array}$ & $\begin{array}{l}0.8303^{* * *} \\
(0.2566)\end{array}$ & $\begin{array}{l}0.8507^{* * *} \\
(0.2322)\end{array}$ & $\begin{array}{l}0.1815^{* * *} \\
(0.0278)\end{array}$ & $\begin{array}{l}-0.1137 \\
(0.0980)\end{array}$ \\
\hline $\operatorname{Ln} G D P_{j, t-1}$ & $\begin{array}{l}2.0384^{* * *} \\
(0.1861)\end{array}$ & $\begin{array}{l}2.0145^{* * *} \\
(0.1830)\end{array}$ & $\begin{array}{l}2.4175^{* * *} \\
(0.1287)\end{array}$ & $\begin{array}{l}2.4056^{* * *} \\
(0.1278)\end{array}$ & $\begin{array}{l}2.0629^{* * *} \\
(0.1882)\end{array}$ & $\begin{array}{l}2.1486^{* * *} \\
(0.1893)\end{array}$ & $\begin{array}{l}2.4730^{* * *} \\
(0.1322)\end{array}$ & $\begin{array}{l}2.4147^{* * *} \\
(0.1320)\end{array}$ \\
\hline Trade openness $j_{j, t-1}$ & $\begin{array}{l}1.2286^{* * *} \\
(0.1711)\end{array}$ & $\begin{array}{l}1.2098^{* * *} \\
(0.1711)\end{array}$ & $\begin{array}{l}1.4655^{* * *} \\
(0.1130)\end{array}$ & $\begin{array}{l}1.4102^{* * *} \\
(0.1145)\end{array}$ & $\begin{array}{l}1.2512^{* * *} \\
(0.1716)\end{array}$ & $\begin{array}{l}1.3123^{* * *} \\
(0.1738)\end{array}$ & $\begin{array}{l}1.5089^{* * *} \\
(0.1130)\end{array}$ & $\begin{array}{l}1.4267^{* * *} \\
(0.1170)\end{array}$ \\
\hline Regulatory quality $y_{j, t-1}$ & $\begin{array}{l}0.1632^{*} \\
(0.0838)\end{array}$ & $\begin{array}{l}0.1615^{*} \\
(0.0864)\end{array}$ & $\begin{array}{l}0.1508^{* *} \\
(0.0623)\end{array}$ & $\begin{array}{l}0.1312^{* *} \\
(0.0633)\end{array}$ & $\begin{array}{l}0.1664^{*} \\
(0.0861)\end{array}$ & $\begin{array}{l}0.1874^{* *} \\
(0.0896)\end{array}$ & $\begin{array}{l}0.1613^{* *} \\
(0.0637)\end{array}$ & $\begin{array}{l}0.1473^{* *} \\
(0.0643)\end{array}$ \\
\hline Ln productivity $j_{j, t-1}$ & $\begin{array}{l}-0.0913 \\
(0.1144)\end{array}$ & $\begin{array}{l}-0.2436^{*} \\
(0.1456)\end{array}$ & $\begin{array}{l}0.1941^{* * *} \\
(0.0744)\end{array}$ & $\begin{array}{l}0.7953^{* * *} \\
(0.2137)\end{array}$ & $\begin{array}{l}-0.0796 \\
(0.1176)\end{array}$ & $\begin{array}{l}-0.6819^{* * *} \\
(0.2179)\end{array}$ & $\begin{array}{l}0.1623^{* *} \\
(0.0797)\end{array}$ & $\begin{array}{l}0.7530^{* *} \\
(0.2998)\end{array}$ \\
\hline Ln tax burden $_{j, t-1}$ & $\begin{array}{l}-1.3062 \\
(0.9781)\end{array}$ & $\begin{array}{l}-1.4412 \\
(0.9733)\end{array}$ & $\begin{array}{l}-0.5393 \\
(0.6867)\end{array}$ & $\begin{array}{l}-0.3775 \\
(0.7153)\end{array}$ & $\begin{array}{l}-1.3303 \\
(0.9801)\end{array}$ & $\begin{array}{l}-1.8883^{*} \\
(1.0297)\end{array}$ & $\begin{array}{l}-0.5805 \\
(0.6904)\end{array}$ & $\begin{array}{l}-0.3932 \\
(0.7337)\end{array}$ \\
\hline$H C D_{i j, t-1}$ & $\begin{array}{l}-6.6406^{* * *} \\
(1.0768)\end{array}$ & $\begin{array}{l}-6.8512^{* * *} \\
(1.0651)\end{array}$ & $\begin{array}{l}-1.1348 \\
(1.1547)\end{array}$ & $\begin{array}{l}-0.4977 \\
(1.1720)\end{array}$ & $\begin{array}{l}-6.0828^{* * *} \\
(1.0807)\end{array}$ & $\begin{array}{l}-6.2345^{* * *} \\
(1.0705)\end{array}$ & $\begin{array}{l}-1.2969 \\
(1.2277)\end{array}$ & $\begin{array}{l}-0.7618 \\
(1.2444)\end{array}$ \\
\hline Ln Labor freedom $_{j, t-1}$ & $\begin{array}{l}1.5927^{* *} \\
(0.6547)\end{array}$ & $\begin{array}{l}1.7265^{* *} \\
(0.6774)\end{array}$ & $\begin{array}{l}2.0407^{* * *} \\
(0.5275)\end{array}$ & $\begin{array}{l}2.1382^{* * *} \\
(0.5319)\end{array}$ & $\begin{array}{l}1.6244^{* *} \\
(0.6616)\end{array}$ & $\begin{array}{l}1.7586^{* *} \\
(0.6903)\end{array}$ & $\begin{array}{l}2.1515^{* * *} \\
(0.5357)\end{array}$ & $\begin{array}{l}2.2519^{* * *} \\
(0.5386)\end{array}$ \\
\hline $\begin{array}{l}\text { Time - FE } \\
\text { Country - FE }\end{array}$ & $\begin{array}{l}\text { No } \\
\text { No }\end{array}$ & $\begin{array}{l}\text { Yes } \\
\text { No }\end{array}$ & $\begin{array}{l}\text { No } \\
\text { Yes }\end{array}$ & $\begin{array}{l}\text { Yes } \\
\text { Yes }\end{array}$ & $\begin{array}{l}\text { No } \\
\text { No }\end{array}$ & $\begin{array}{l}\text { Yes } \\
\text { No }\end{array}$ & $\begin{array}{l}\text { No } \\
\text { Yes }\end{array}$ & $\begin{array}{l}\text { Yes } \\
\text { Yes }\end{array}$ \\
\hline $\begin{array}{l}R^{2} \\
\text { Observations }\end{array}$ & $\begin{array}{l}0.5114 \\
19449\end{array}$ & $\begin{array}{l}0.5213 \\
19449\end{array}$ & $\begin{array}{l}0.7875 \\
19449\end{array}$ & $\begin{array}{l}0.7991 \\
19449\end{array}$ & 0.4996 & 0.5144 & 0.7834 & 0.7935 \\
\hline
\end{tabular}


Table 11: The Impact of FDI Restrictive Measures in the Agriculuture and Mining sectors on FDI stocks: OECD vs. Africa Countries

\begin{tabular}{|c|c|c|c|c|}
\hline \multirow{2}{*}{$\begin{array}{l}\text { Specification } \\
\text { Dependant variable } \\
\text { Years } \\
\text { Model }\end{array}$} & \multicolumn{4}{|c|}{$\begin{array}{l}\text { PPML Estimate } \\
\frac{F D I_{i, t}}{\text { GDPdeflator }_{i, j, t}} \\
\mathbf{2 0 1 0 - 2 0 1 9}\end{array}$} \\
\hline & (1) & (2) $\quad \mathrm{U}$ & (3) & (4) \\
\hline FDI RI Agriculture ${ }_{j, t-1}$ & $\begin{array}{l}4.4306 \\
(6.3253)\end{array}$ & $\begin{array}{l}-15.9606 \\
(15.4882)\end{array}$ & $\begin{array}{l}6.7824 \\
(5.2212)\end{array}$ & $\begin{array}{l}6.8618 \\
(5.0804)\end{array}$ \\
\hline FDI RI Mining Quarrying ${ }_{j, t-1}$ & $\begin{array}{l}-52.9798^{*} \\
(29.1565)\end{array}$ & $\begin{array}{l}71.6922 \\
(60.2865)\end{array}$ & $\begin{array}{l}-53.0927^{* *} \\
(23.6493)\end{array}$ & $\begin{array}{l}-56.3174^{* *} \\
(23.4842)\end{array}$ \\
\hline OECD dum ${ }_{j} *$ FDI RI Agriculture & $\begin{array}{l}-4.7502 \\
(6.4052)\end{array}$ & $\begin{array}{l}15.4586 \\
(15.4586)\end{array}$ & $\begin{array}{l}-8.0206 \\
(5.2854)\end{array}$ & $\begin{array}{l}-8.1342 \\
(5.1392)\end{array}$ \\
\hline OECD dum $_{j}$ FDI RI Mining Quarrying & $\begin{array}{l}48.1582^{*} \\
(29.0632)\end{array}$ & $\begin{array}{l}-76.4974 \\
(60.0520)\end{array}$ & $\begin{array}{l}51.4118^{* *} \\
(23.5483)\end{array}$ & $\begin{array}{l}54.7172^{* *} \\
(23.4172)\end{array}$ \\
\hline OECD dum & $\begin{array}{l}0.7574 \\
(0.5399)\end{array}$ & $\begin{array}{l}-0.8539 \\
(0.6191)\end{array}$ & $\begin{array}{l}0.9605^{* *} \\
(0.4485)\end{array}$ & $\begin{array}{l}1.6248^{*} \\
(0.9838)\end{array}$ \\
\hline $\operatorname{Ln} F D I_{i j, t-1}$ & $\begin{array}{l}0.1508^{* *} \\
(0.0674)\end{array}$ & $\begin{array}{l}0.0772 \\
(0.0771)\end{array}$ & $\begin{array}{l}0.1953^{* * *} \\
(0.0449)\end{array}$ & $\begin{array}{l}0.0958^{* *} \\
(0.0478)\end{array}$ \\
\hline Ln distance $e_{i j, t-1}$ & $\begin{array}{l}-1.9904^{* * *} \\
(0.2999)\end{array}$ & $\begin{array}{l}-2.0189^{* * *} \\
(0.3024)\end{array}$ & $\begin{array}{l}-0.9990^{* * *} \\
(0.1539)\end{array}$ & $\begin{array}{l}-1.0245^{* * *} \\
(0.1596)\end{array}$ \\
\hline Common border $r_{i j, t-1}$ & $\begin{array}{l}-0.3151 \\
(0.2694)\end{array}$ & $\begin{array}{l}-0.3267 \\
(0.2687)\end{array}$ & $\begin{array}{l}-0.3415^{* *} \\
(0.1601)\end{array}$ & $\begin{array}{l}-0.3537^{* *} \\
(0.1618)\end{array}$ \\
\hline Common lang lij,t-1 $_{1}$ & $\begin{array}{l}0.4399 \\
(0.2704)\end{array}$ & $\begin{array}{l}0.4564^{*} \\
(0.2715)\end{array}$ & $\begin{array}{l}0.2757^{*} \\
(0.1485)\end{array}$ & $\begin{array}{l}0.2597^{*} \\
(0.1489)\end{array}$ \\
\hline Colonial links $s_{i j, t-1}$ & $\begin{array}{l}0.5229 \\
(0.3518)\end{array}$ & $\begin{array}{l}0.4702 \\
(0.3523)\end{array}$ & $\begin{array}{l}0.3969^{* * *} \\
(0.1455)\end{array}$ & $\begin{array}{l}0.3983^{* * *} \\
(0.1458)\end{array}$ \\
\hline$R T A_{i j, t-1}$ & $\begin{array}{l}-1.1363^{* * *} \\
(0.3677)\end{array}$ & $\begin{array}{l}-1.1015^{* * *} \\
(0.3591)\end{array}$ & $\begin{array}{l}0.4250^{* * *} \\
(0.1649)\end{array}$ & $\begin{array}{l}0.4031^{* *} \\
(0.1738)\end{array}$ \\
\hline$B I T_{i j, t-1}$ & $\begin{array}{l}-0.6916^{* * *} \\
(0.1816)\end{array}$ & $\begin{array}{l}-0.7232^{* * *} \\
(0.1836)\end{array}$ & $\begin{array}{l}-0.3477^{*} \\
(0.1896)\end{array}$ & $\begin{array}{l}-0.3333^{*} \\
(0.1924)\end{array}$ \\
\hline $\operatorname{Ln} G D P_{i, t-1}$ & $\begin{array}{l}0.7136^{* * *} \\
(0.2589)\end{array}$ & $\begin{array}{l}0.7984^{* * *} \\
(0.2105)\end{array}$ & $\begin{array}{l}0.2226^{* * *} \\
(0.0311)\end{array}$ & $\begin{array}{l}0.1268 \\
(0.1059)\end{array}$ \\
\hline$L n G D P_{j, t-1}$ & $\begin{array}{l}1.9473^{* * *} \\
(0.1782)\end{array}$ & $\begin{array}{l}2.1159^{* * *} \\
(0.1731)\end{array}$ & $\begin{array}{l}2.4856^{* * *} \\
(0.1535)\end{array}$ & $\begin{array}{l}2.4634^{* * *} \\
(0.1594)\end{array}$ \\
\hline Trade openness $j_{j, t-1}$ & $\begin{array}{l}1.1237^{* * *} \\
(0.1727)\end{array}$ & $\begin{array}{l}1.2692^{* * *} \\
(0.1810)\end{array}$ & $\begin{array}{l}1.4884^{* * *} \\
(0.1156)\end{array}$ & $\begin{array}{l}1.4489^{* * *} \\
(0.1253)\end{array}$ \\
\hline Regulatory quality $y_{j, t-1}$ & $\begin{array}{l}0.1141 \\
(0.0873)\end{array}$ & $\begin{array}{l}0.1766^{*} \\
(0.0966)\end{array}$ & $\begin{array}{l}0.1310^{* *} \\
(0.0613)\end{array}$ & $\begin{array}{l}0.1300^{* *} \\
(0.0631)\end{array}$ \\
\hline Ln productivity $y_{j, t-1}$ & $\begin{array}{l}0.4983^{* *} \\
(0.2014)\end{array}$ & $\begin{array}{l}-0.6048 \\
(0.5201)\end{array}$ & $\begin{array}{l}0.4996^{* * *} \\
(0.1597)\end{array}$ & $\begin{array}{l}0.7315^{* *} \\
(0.3582)\end{array}$ \\
\hline Ln tax burden $_{j, t-1}$ & $\begin{array}{l}-0.4218 \\
(0.9737)\end{array}$ & $\begin{array}{l}-1.1113 \\
(1.0413)\end{array}$ & $\begin{array}{l}-0.2210 \\
(0.7134)\end{array}$ & $\begin{array}{l}-0.2156 \\
(0.7604)\end{array}$ \\
\hline$H C D_{i j, t-1}$ & $\begin{array}{l}-6.0677^{* * *} \\
(1.3539)\end{array}$ & $\begin{array}{l}-5.9650^{* * *} \\
(1.3248)\end{array}$ & $\begin{array}{l}-0.3543 \\
(1.5101)\end{array}$ & $\begin{array}{l}0.0549 \\
(1.5138)\end{array}$ \\
\hline Ln Labor freedom frt $_{j, 1}$ & $\begin{array}{l}2.0241^{* * *} \\
(0.7318)\end{array}$ & $\begin{array}{l}2.2859^{* * *} \\
(0.7600)\end{array}$ & $\begin{array}{l}2.4499^{* * *} \\
(0.5708)\end{array}$ & $\begin{array}{l}2.5550^{* * *} \\
(0.5907)\end{array}$ \\
\hline $\begin{array}{l}\text { Time - FE } \\
\text { Country }-F E \\
R^{2} \\
\text { Observations }\end{array}$ & $\begin{array}{l}\text { No } \\
\text { No } \\
0.5211 \\
15213\end{array}$ & $\begin{array}{l}\text { Yes } \\
\text { No } \\
0.5383 \\
15213\end{array}$ & $\begin{array}{l}\text { No } \\
\text { Yes } \\
0.7967 \\
15213\end{array}$ & $\begin{array}{l}\text { Yes } \\
\text { Yes } \\
0.8052 \\
15213\end{array}$ \\
\hline
\end{tabular}

Notes: The dependent variable is bilateral FDI stocks. Standard errors are reported respectively at the 10\%

in parentheses and clustered by country- pair level. ${ }^{*}, * *, * *$ denote signicance, $5 \%$ and $1 \%$ levels 
Table 12: Gravity Estimation Results of Impacts of Restrictive Measures on FDI Stocks: $\mathrm{OECD}$ vs. All emerging countries including Africa

\begin{tabular}{|c|c|c|c|c|c|c|c|c|}
\hline \multirow{3}{*}{$\begin{array}{l}\text { Model } \\
\text { FDIRI Global }{ }_{j, t-1}\end{array}$} & \multicolumn{4}{|c|}{ FDI RI global } & \multicolumn{4}{|c|}{ Sectoral FDI RI } \\
\hline & & (2) & (3) & & (5) & (6) & $(7)$ & (8) \\
\hline & $\begin{array}{l}-1.1256 \\
(1.2473)\end{array}$ & $\begin{array}{l}-0.9743 \\
(1.3225)\end{array}$ & $\begin{array}{l}-2.9996^{* * *} \\
(0.8606)\end{array}$ & $\begin{array}{l}-2.9961^{* * *} \\
(0.8572)\end{array}$ & & & & \\
\hline FDI RI Primary $y_{j, t-1}$ & & & & & $\begin{array}{l}3.3042^{*} \\
(1.8542)\end{array}$ & $\begin{array}{l}2.1786 \\
(2.1177)\end{array}$ & $\begin{array}{l}0.0024 \\
(1.6079)\end{array}$ & $\begin{array}{l}1.1242 \\
(1.5991)\end{array}$ \\
\hline FDI RI Secondary $y_{j, t-1}$ & & & & & $\begin{array}{l}4.5390^{*} \\
(2.7509)\end{array}$ & $\begin{array}{l}5.2919^{*} \\
(2.8590)\end{array}$ & $\begin{array}{l}3.5005^{* *} \\
(1.5584)\end{array}$ & $\begin{array}{l}3.1564^{*} \\
(1.6280)\end{array}$ \\
\hline FDI RI Tertiary $y_{j, t-1}$ & & & & & $\begin{array}{l}-6.7533^{* *} \\
(2.8166)\end{array}$ & $\begin{array}{l}-5.8418^{* *} \\
(2.9723)\end{array}$ & $\begin{array}{l}-4.2562^{* *} \\
(1.7295)\end{array}$ & $\begin{array}{l}-5.2182^{* * *} \\
(1.8172)\end{array}$ \\
\hline OECD dum ${ }_{j} *$ FDI RI Global & $\begin{array}{l}-0.3845 \\
(2.6583)\end{array}$ & $\begin{array}{l}-0.7965 \\
(2.6414)\end{array}$ & $\begin{array}{l}1.2851 \\
(1.6949)\end{array}$ & $\begin{array}{l}1.7642 \\
(1.8593)\end{array}$ & & & & \\
\hline OECD dum $_{j}$ FDI RI Primary & & & & & $\begin{array}{l}-1.1610 \\
(2.5509)\end{array}$ & $\begin{array}{l}0.1110 \\
(2.7796)\end{array}$ & $\begin{array}{l}1.6178 \\
(1.7773)\end{array}$ & $\begin{array}{l}0.4286 \\
(1.8011)\end{array}$ \\
\hline OECD dum ${ }_{j} *$ FDI RI Secondary & & & & & $\begin{array}{l}-4.3517 \\
(3.4762)\end{array}$ & $\begin{array}{l}-4.7945 \\
(3.4757)\end{array}$ & $\begin{array}{l}-3.5131 \\
(2.5677)\end{array}$ & $\begin{array}{l}-2.8719 \\
(2.5993)\end{array}$ \\
\hline OECD dum ${ }_{j} *$ FDI RI Tertiary & & & & & $\begin{array}{l}2.9679 \\
(3.6022)\end{array}$ & $\begin{array}{l}1.3991 \\
(3.7607)\end{array}$ & $\begin{array}{l}0.7142 \\
(2.4712)\end{array}$ & $\begin{array}{l}1.8804 \\
(2.7528)\end{array}$ \\
\hline$O E C D d u m_{j}$ & $\begin{array}{l}-0.2421 \\
(0.4680)\end{array}$ & $\begin{array}{l}-0.4509 \\
(0.4486)\end{array}$ & $\begin{array}{l}0.2990 \\
(0.3004)\end{array}$ & $\begin{array}{l}1.7348^{* * *} \\
(0.5517)\end{array}$ & $\begin{array}{l}-0.3226 \\
(0.4281)\end{array}$ & $\begin{array}{l}-0.5497 \\
(0.4119)\end{array}$ & $\begin{array}{l}0.1778 \\
(0.3083)\end{array}$ & $\begin{array}{l}1.4397^{* * *} \\
(0.4985)\end{array}$ \\
\hline Ln $F D I_{i j, t-1}$ & $\begin{array}{l}0.1954^{* * *} \\
(0.0636)\end{array}$ & $\begin{array}{l}0.1366^{*} \\
(0.0730)\end{array}$ & $\begin{array}{l}0.2163^{* * *} \\
(0.0447)\end{array}$ & $\begin{array}{l}0.1035^{* *} \\
(0.0481)\end{array}$ & $\begin{array}{l}0.1868^{* * *} \\
(0.0648)\end{array}$ & $\begin{array}{l}0.1236^{*} \\
(0.0748)\end{array}$ & $\begin{array}{l}0.2113^{* * *} \\
(0.0428)\end{array}$ & $\begin{array}{l}0.1020^{* *} \\
(0.0456)\end{array}$ \\
\hline Ln distance $i j, t-1$ & $\begin{array}{l}-1.9771^{* * *} \\
(0.2636)\end{array}$ & $\begin{array}{l}-1.9741^{* * *} \\
(0.2680)\end{array}$ & $\begin{array}{l}-1.1012^{* * *} \\
(0.1328)\end{array}$ & $\begin{array}{l}-1.1291^{* * *} \\
(0.1368)\end{array}$ & $\begin{array}{l}-2.0136^{* * *} \\
(0.2704)\end{array}$ & $\begin{array}{l}-2.0097^{* * *} \\
(0.2753)\end{array}$ & $\begin{array}{l}-1.1251^{* * *} \\
(0.1438)\end{array}$ & $\begin{array}{l}-1.1560^{* * *} \\
(0.1498)\end{array}$ \\
\hline Common border ${ }_{i j, t-1}$ & $\begin{array}{l}-0.4961^{*} \\
(0.2731)\end{array}$ & $\begin{array}{l}-0.4713^{*} \\
(0.2728)\end{array}$ & $\begin{array}{l}-0.4307^{* * *} \\
(0.1490)\end{array}$ & $\begin{array}{l}-0.4493^{* * *} \\
(0.1505)\end{array}$ & $\begin{array}{l}-0.4683^{*} \\
(0.2808)\end{array}$ & $\begin{array}{l}-0.4430 \\
(0.2811)\end{array}$ & $\begin{array}{l}-0.3969^{* * *} \\
(0.1441)\end{array}$ & $\begin{array}{l}-0.4154^{* * *} \\
(0.1450)\end{array}$ \\
\hline Common $\operatorname{lang}_{i j, t-1}$ & $\begin{array}{l}0.4742^{*} \\
(0.2649)\end{array}$ & $\begin{array}{l}0.4856^{*} \\
(0.2653)\end{array}$ & $\begin{array}{l}0.3260^{* *} \\
(0.1477)\end{array}$ & $\begin{array}{l}0.3006^{* *} \\
(0.1486)\end{array}$ & $\begin{array}{l}0.4747^{*} \\
(0.2662)\end{array}$ & $\begin{array}{l}0.4869^{*} \\
(0.2662)\end{array}$ & $\begin{array}{l}0.3371^{* *} \\
(0.1462)\end{array}$ & $\begin{array}{l}0.3126^{* *} \\
(0.1474)\end{array}$ \\
\hline Colonial links $s_{i j, t-1}$ & $\begin{array}{l}0.6043^{*} \\
(0.3346)\end{array}$ & $\begin{array}{l}0.5744^{*} \\
(0.3379)\end{array}$ & $\begin{array}{l}0.3842^{* *} \\
(0.1545)\end{array}$ & $\begin{array}{l}0.3895^{* *} \\
(0.1563)\end{array}$ & $\begin{array}{l}0.5380 \\
(0.3441)\end{array}$ & $\begin{array}{l}0.4997 \\
(0.3476)\end{array}$ & $\begin{array}{l}0.3246^{* *} \\
(0.1485)\end{array}$ & $\begin{array}{l}0.3320^{* *} \\
(0.1524)\end{array}$ \\
\hline$R T A_{i j, t-1}$ & $\begin{array}{l}-0.6711^{* * *} \\
(0.2485)\end{array}$ & $\begin{array}{l}-0.6902^{* * *} \\
(0.2498)\end{array}$ & $\begin{array}{l}0.3709^{* * *} \\
(0.1392)\end{array}$ & $\begin{array}{l}0.3399^{* *} \\
(0.1445)\end{array}$ & $\begin{array}{l}-0.7202^{* * *} \\
(0.2586)\end{array}$ & $\begin{array}{l}-0.7397^{* * *} \\
(0.2602)\end{array}$ & $\begin{array}{l}0.3622^{* *} \\
(0.1519)\end{array}$ & $\begin{array}{l}0.3256^{* *} \\
(0.1579)\end{array}$ \\
\hline$B I T_{i j, t-1}$ & $\begin{array}{l}-0.7235^{* * *} \\
(0.1672)\end{array}$ & $\begin{array}{l}-0.7344^{* * *} \\
(0.1657)\end{array}$ & $\begin{array}{l}-0.3811^{* *} \\
(0.1716)\end{array}$ & $\begin{array}{l}-0.3403^{*} \\
(0.1762)\end{array}$ & $\begin{array}{l}-0.7611^{* * *} \\
(0.1659)\end{array}$ & $\begin{array}{l}-0.7801^{* * *} \\
(0.1645)\end{array}$ & $\begin{array}{l}-0.5056^{* * *} \\
(0.1816)\end{array}$ & $\begin{array}{l}-0.4657^{* *} \\
(0.1883)\end{array}$ \\
\hline $\operatorname{Ln} G D P_{i, t-1}$ & $\begin{array}{l}0.8493^{* * *} \\
(0.2575)\end{array}$ & $\begin{array}{l}0.8505^{* * *} \\
(0.2566)\end{array}$ & $\begin{array}{l}0.2065^{* * *} \\
(0.0305)\end{array}$ & $\begin{array}{l}-0.0635 \\
(0.0680)\end{array}$ & $\begin{array}{l}0.8338^{* * *} \\
(0.2589)\end{array}$ & $\begin{array}{l}0.8358^{* * *} \\
(0.2569)\end{array}$ & $\begin{array}{l}0.2093^{* * *} \\
(0.0306)\end{array}$ & $\begin{array}{l}-0.0390 \\
(0.0669)\end{array}$ \\
\hline $\operatorname{Ln} G D P_{j, t-1}$ & $\begin{array}{l}1.9525^{* * *} \\
(0.1788)\end{array}$ & $\begin{array}{l}1.9383^{* * *} \\
(0.1762)\end{array}$ & $\begin{array}{l}2.4245^{* * *} \\
(0.1309)\end{array}$ & $\begin{array}{l}2.4079^{* * *} \\
(0.1273)\end{array}$ & $\begin{array}{l}1.8073^{* * *} \\
(0.1721)\end{array}$ & $\begin{array}{l}1.7914^{* * *} \\
(0.1691)\end{array}$ & $\begin{array}{l}2.2793^{* * *} \\
(0.1268)\end{array}$ & $\begin{array}{l}2.2682^{* * *} \\
(0.1273)\end{array}$ \\
\hline Trade openness $j_{j, t-1}$ & $\begin{array}{l}1.1521^{* * *} \\
(0.1775)\end{array}$ & $\begin{array}{l}1.1366^{* * *} \\
(0.1772)\end{array}$ & $\begin{array}{l}1.4490^{* * *} \\
(0.1164)\end{array}$ & $\begin{array}{l}1.3982^{* * *} \\
(0.1166)\end{array}$ & $\begin{array}{l}1.1033^{* * *} \\
(0.1766)\end{array}$ & $\begin{array}{l}1.0873^{* * *} \\
(0.1759)\end{array}$ & $\begin{array}{l}1.3928^{* * *} \\
(0.1119)\end{array}$ & $\begin{array}{l}1.3415^{* * *} \\
(0.1135)\end{array}$ \\
\hline Regulatory quality $_{j, t-1}$ & $\begin{array}{l}0.2005^{* *} \\
(0.0867)\end{array}$ & $\begin{array}{l}0.1978^{* *} \\
(0.0908)\end{array}$ & $\begin{array}{l}0.1790^{* * *} \\
(0.0626)\end{array}$ & $\begin{array}{l}0.1621^{* *} \\
(0.0645)\end{array}$ & $\begin{array}{l}0.1771^{* *} \\
(0.0814)\end{array}$ & $\begin{array}{l}0.1773^{* *} \\
(0.0855)\end{array}$ & $\begin{array}{l}0.1664^{* * *} \\
(0.0601)\end{array}$ & $\begin{array}{l}0.1525^{* *} \\
(0.0617)\end{array}$ \\
\hline Ln productivity prt-1 $_{1}$ & $\begin{array}{l}0.0368 \\
(0.1197)\end{array}$ & $\begin{array}{l}-0.0820 \\
(0.1348)\end{array}$ & $\begin{array}{l}0.2615^{* * *} \\
(0.0763)\end{array}$ & $\begin{array}{l}0.7824^{* * *} \\
(0.1792)\end{array}$ & $\begin{array}{l}0.1217 \\
(0.1154)\end{array}$ & $\begin{array}{l}-0.0155 \\
(0.1401)\end{array}$ & $\begin{array}{l}0.2806^{* * *} \\
(0.0752)\end{array}$ & $\begin{array}{l}0.7370^{* * *} \\
(0.1621)\end{array}$ \\
\hline Ln tax burden $_{j, t-1}$ & $\begin{array}{l}-0.9246 \\
(0.8583)\end{array}$ & $\begin{array}{l}-1.0305 \\
(0.8586)\end{array}$ & $\begin{array}{l}-0.2375 \\
(0.6579)\end{array}$ & $\begin{array}{l}-0.1279 \\
(0.6719)\end{array}$ & $\begin{array}{l}-0.3930 \\
(0.8710)\end{array}$ & $\begin{array}{l}-0.4514 \\
(0.8866)\end{array}$ & $\begin{array}{l}0.0872 \\
(0.6451)\end{array}$ & $\begin{array}{l}0.2146 \\
(0.6649)\end{array}$ \\
\hline$H C D_{i j, t-1}$ & $\begin{array}{l}-7.1570^{* * *} \\
(1.0189)\end{array}$ & $\begin{array}{l}-7.3917^{* * *} \\
(1.0036)\end{array}$ & $\begin{array}{l}-0.8946 \\
(1.1099)\end{array}$ & $\begin{array}{l}-0.3179 \\
(1.1202)\end{array}$ & $\begin{array}{l}-7.2453^{* * *} \\
(1.0396)\end{array}$ & $\begin{array}{l}-7.4677^{* * *} \\
(1.0243)\end{array}$ & $\begin{array}{l}-1.0193 \\
(1.1249)\end{array}$ & $\begin{array}{l}-0.5228 \\
(1.1260)\end{array}$ \\
\hline Ln Labor freedom $_{j, t-1}$ & $\begin{array}{l}1.8006^{* * *} \\
(0.6231)\end{array}$ & $\begin{array}{l}1.9630^{* * *} \\
(0.6433)\end{array}$ & $\begin{array}{l}2.3156^{* * *} \\
(0.5164)\end{array}$ & $\begin{array}{l}2.3632^{* * *} \\
(0.5304)\end{array}$ & $\begin{array}{l}1.8708^{* * *} \\
(0.6430)\end{array}$ & $\begin{array}{l}2.0389^{* * *} \\
(0.6668)\end{array}$ & $\begin{array}{l}2.3132^{* * *} \\
(0.5148)\end{array}$ & $\begin{array}{l}2.3505^{* * *} \\
(0.5338)\end{array}$ \\
\hline $\begin{array}{l}\text { Time -FE } \\
\text { Country - FE } \\
R^{2} \\
\text { Observations }\end{array}$ & $\begin{array}{l}\text { No } \\
\text { No } \\
0.5190 \\
21566\end{array}$ & $\begin{array}{l}\text { Yes } \\
\text { No } \\
0.5282 \\
21566 \\
\end{array}$ & $\begin{array}{l}\text { No } \\
\text { Yes } \\
0.7932 \\
21566\end{array}$ & $\begin{array}{l}\text { Yes } \\
\text { Yes } \\
0.8039 \\
21566\end{array}$ & $\begin{array}{l}\text { No } \\
\text { No } \\
0.5228 \\
21566 \\
\end{array}$ & $\begin{array}{l}\text { Yes } \\
\text { No } \\
0.5324 \\
21566 \\
\end{array}$ & $\begin{array}{l}\text { No } \\
\text { Yes } \\
0.7956 \\
21566 \\
\end{array}$ & $\begin{array}{l}\text { Yes } \\
\text { Yes } \\
0.8061 \\
21566\end{array}$ \\
\hline
\end{tabular}


Table .13: OECD, Emerging and Africa Countries

\begin{tabular}{l|l|l}
\hline \hline OECD & Emerging & Africa \\
\hline Austria & Argentina & Egypt \\
Belgium & Brazil & Morocco \\
Canada & China & South Africa \\
Chile & Colombia & Tunisia \\
Czech Republic & $\begin{array}{l}\text { India } \\
\text { Indonesia }\end{array}$ & \\
Denmark & Malaysia & \\
Estonia & Russia & \\
Finland & South Africa & \\
France & Thailand & \\
Germany & & \\
Greece & & \\
Hungary & & \\
Iceland & \\
Ireland & \\
Israel & \\
Italy & \\
Japan & \\
Korea & \\
Latvia & \\
Lithuania & \\
Luxembourg & \\
Mexico & \\
Netherlands & \\
New Zealand & \\
Norway & \\
Poland & \\
Portugal & \\
Slovak Republic & & \\
Slovenia & & \\
Spain & \\
Sweden & \\
Switzerland & \\
Turkey & \\
United Kingdom & \\
United States & & \\
\hline \hline
\end{tabular}




\section{A. Appendix}

Table A.1: Variable Description and Sources

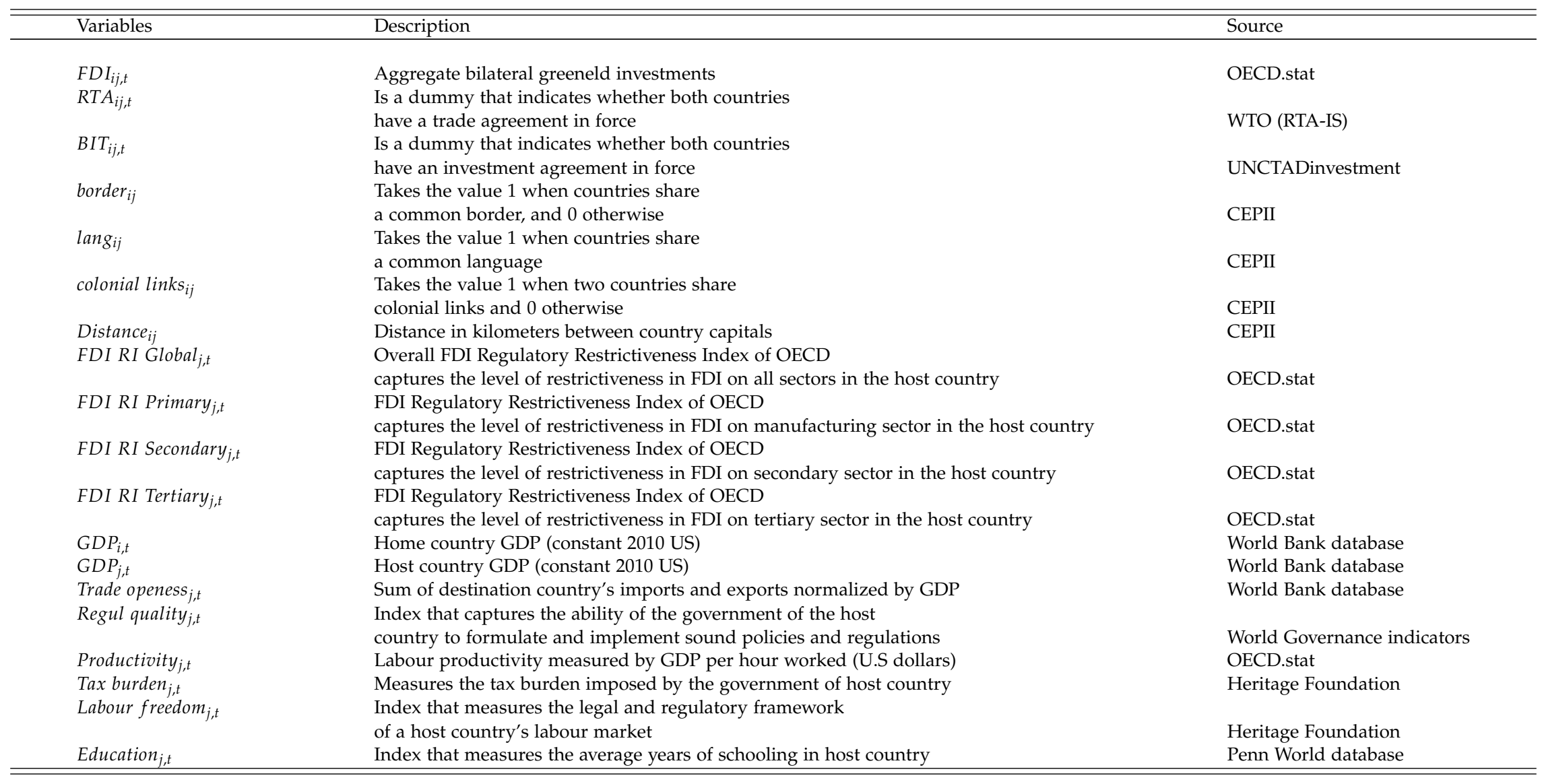


Table A.2: Descriptive Statistics

\begin{tabular}{|c|c|c|c|c|c|}
\hline Variables & obs. & Mean & Std. Dev. & Min & Max \\
\hline \multicolumn{6}{|l|}{ Bilateral FDI } \\
\hline$F D I_{i j, t}$ & 21,960 & 7345.433 & 44071.73 & 0 & 1056271 \\
\hline \multicolumn{6}{|c|}{ Traditional variables of the gravity model } \\
\hline$B I T_{i j, t}$ & 21,960 & 0.5297814 & 0.4991236 & 0 & 1 \\
\hline$R T A_{i j, t}$ & 21,960 & 0.6142077 & 0.486793 & 0 & 1 \\
\hline border $_{i j}$ & 21,960 & 0.0441712 & 0.20548 & 0 & 1 \\
\hline $\operatorname{lang}_{i j}$ & 21,960 & 0.0619308 & 0.2410353 & 0 & 1 \\
\hline colonial links $_{i j}$ & 21,960 & 0.0350638 & 0.1839452 & 0 & 1 \\
\hline Ln distance $_{i j}$ & 21,960 & 3.613527 & 0.4664477 & 1.775372 & 4.29195 \\
\hline$L n G D P_{j, t}$ & 21,960 & 11.65486 & 0.6676412 & 10.1362 & 13.26245 \\
\hline $\operatorname{Ln} G D P_{i, t}$ & 21,960 & 10.85451 & 2.929926 & 1.011451 & 13.26245 \\
\hline \multicolumn{6}{|c|}{ Host country specific characteristics } \\
\hline Regul quality $_{j, t}$ & 21,960 & 0.9679318 & 0.739656 & -1.074257 & 2.088636 \\
\hline \multicolumn{6}{|c|}{ FDI determinants in Host country } \\
\hline Productivity $_{j, t}$ & 21,959 & 7476.289 & 15497.5 & 19.43301 & 59390.48 \\
\hline Tax burden $_{j, t}$ & 21,960 & 68.28214 & 12.28882 & 35.9 & 93.6 \\
\hline 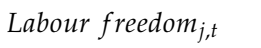 & 21,960 & 62.14343 & 14.75172 & 21.7 & 98.5 \\
\hline Education $_{j, t}$ & 21,864 & 3.165414 & 0.4624206 & 1.750288 & 3.89154 \\
\hline Education $_{i, t}$ & 21,760 & 3.121759 & 0.5139138 & 1.750288 & 3.89154 \\
\hline Trade openess $s_{j, t}$ & 21,864 & 0.9518639 & 0.6097027 & 0.2248623 & 4.08362 \\
\hline \multicolumn{6}{|c|}{ FDI Regulatory Restrictiveness Index } \\
\hline FDI RI Global $_{j, t}$ & 21,960 & 0.089699 & 0.0878699 & 0.004 & 0.435 \\
\hline FDI RI Primary $y_{j, t}$ & 21,960 & 0.1192143 & 0.1168962 & 0 & 0.495 \\
\hline FDI RI Secondary $j_{j, t}$ & 21,960 & 0.0403809 & 0.0612678 & 0 & 0.295 \\
\hline FDI RI Tertiary $j_{j, t}$ & 21,960 & 0.1095849 & 0.1073558 & 0.007 & 0.506 \\
\hline
\end{tabular}


Table A.3: Cross-Correlation Table

\begin{tabular}{|c|c|c|c|c|c|c|c|c|c|c|c|c|c|c|c|c|c|c|c|c|}
\hline Variables & $F D I$ & BIT & $R T A$ & border & lang & $\begin{array}{l}\text { colonial } \\
\text { links }\end{array}$ & $\begin{array}{l}\text { Ln dis } \\
\text { tance }\end{array}$ & $\begin{array}{l}\text { Product } \\
\text { ivity }\end{array}$ & $\begin{array}{l}\text { Tax } \\
\text { burden }\end{array}$ & $\begin{array}{l}\text { Labour } \\
\text { freedom }\end{array}$ & $\begin{array}{l}\text { Regul } \\
\text { quality }\end{array}$ & $L n G D P_{j}$ & Ln $G D P_{i}$ & $\begin{array}{l}\text { FDI RI } \\
\text { Global }\end{array}$ & $\begin{array}{l}\text { FDI Pri } \\
\text { mary }\end{array}$ & $\begin{array}{l}\text { FDI Secon } \\
\text { dary }\end{array}$ & $\begin{array}{l}\text { FDI Tert } \\
\text { iary }\end{array}$ & $\begin{array}{l}\text { Educa } \\
\text { tion }_{i}\end{array}$ & $\begin{array}{l}\text { Educa } \\
\text { tion }_{j}\end{array}$ & $\begin{array}{l}\text { Trade } \\
\text { openess }\end{array}$ \\
\hline$F D I$ & 1.000 & & & & & & & & & & & & & & & & & & & \\
\hline BIT & -0.039 & 1.000 & & & & & & & & & & & & & & & & & & \\
\hline RTA & -0.015 & 0.290 & 1.000 & & & & & & & & & & & & & & & & & \\
\hline border & 0.110 & 0.096 & 0.105 & 1.000 & & & & & & & & & & & & & & & & \\
\hline lang & 0.150 & -0.097 & -0.008 & 0.202 & 1.000 & & & & & & & & & & & & & & & \\
\hline colonial links & 0.105 & 0.006 & -0.016 & 0.224 & 0.269 & 1.000 & & & & & & & & & & & & & & \\
\hline Ln distance & -0.105 & -0.428 & -0.527 & -0.393 & -0.048 & -0.088 & 1.000 & & & & & & & & & & & & & \\
\hline Productivity & -0.052 & -0.059 & -0.250 & -0.044 & -0.002 & 0.017 & 0.199 & 1.000 & & & & & & & & & & & & \\
\hline Tax burden & -0.063 & -0.070 & -0.105 & -0.056 & -0.041 & -0.015 & 0.142 & 0.320 & 1.000 & & & & & & & & & & & \\
\hline Labor freedom & 0.068 & -0.157 & -0.159 & -0.032 & 0.077 & 0.004 & 0.144 & -0.130 & 0.017 & 1.000 & & & & & & & & & & \\
\hline Regulatory quality & 0.069 & 0.018 & 0.162 & 0.051 & 0.034 & -0.004 & -0.137 & -0.705 & -0.339 & 0.296 & 1.000 & & & & & & & & & \\
\hline $\operatorname{Ln} G D P_{j}$ & 0.124 & -0.056 & -0.237 & 0.019 & 0.069 & 0.053 & 0.173 & 0.047 & -0.244 & 0.176 & -0.044 & 1.000 & & & & & & & & \\
\hline $\operatorname{Ln} G D P_{i}$ & 0.002 & -0.027 & -0.108 & -0.009 & 0.020 & 0.013 & 0.065 & 0.127 & 0.050 & -0.034 & -0.122 & -0.015 & 1.000 & & & & & & & \\
\hline FDI RI Overal & -0.042 & -0.166 & -0.316 & -0.076 & 0.018 & -0.025 & 0.311 & 0.390 & 0.272 & 0.136 & -0.391 & 0.227 & 0.073 & 1.000 & & & & & & \\
\hline FDI RI Primary & -0.005 & -0.146 & -0.255 & -0.077 & 0.021 & -0.011 & 0.307 & 0.264 & 0.141 & 0.122 & -0.288 & 0.277 & 0.054 & 0.886 & 1.000 & & & & & \\
\hline FDI RI Secondary & -0.040 & -0.151 & -0.241 & -0.051 & 0.026 & -0.028 & 0.254 & 0.192 & 0.160 & 0.226 & -0.180 & 0.070 & 0.036 & 0.841 & 0.694 & 1.000 & & & & \\
\hline FDI RI Tertiary & -0.052 & -0.154 & -0.332 & -0.076 & 0.013 & -0.025 & 0.298 & 0.469 & 0.341 & 0.100 & -0.467 & 0.237 & 0.083 & 0.970 & 0.801 & 0.743 & 1.000 & & & \\
\hline Education $_{i}$ & 0.112 & 0.024 & 0.128 & 0.066 & 0.021 & -0.003 & -0.180 & 0.181 & 0.066 & -0.035 & -0.155 & 0.014 & -0.025 & 0.102 & 0.081 & 0.055 & 0.117 & 1.000 & & \\
\hline Education $_{j}$ & 0.082 & 0.035 & 0.045 & 0.082 & -0.014 & 0.012 & -0.147 & -0.463 & -0.223 & 0.354 & 0.665 & 0.028 & -0.132 & -0.326 & -0.302 & -0.119 & -0.375 & -0.127 & 1.000 & \\
\hline Trade openess & 0.049 & 0.170 & 0.196 & 0.044 & 0.011 & -0.041 & -0.270 & -0.239 & 0.043 & -0.060 & 0.289 & -0.529 & -0.061 & -0.303 & -0.290 & -0.232 & -0.294 & -0.050 & 0.232 & 1.000 \\
\hline
\end{tabular}


GREThA UMR CNRS 5113

Université de Bordeaux

Avenue Léon Duguit

33608 Pessac - France

Tel : + 33 (0) 5.56.84.25.75

http://gretha.u-bordeaux.fr/

\section{LAREFI}

Université de Bordeaux

Avenue Léon Duguit

33608 Pessac - France

Tel : +33 (0)5.56.84.25.37

http://larefi.u-bordeaux.fr/

\section{Derniers numéros - Last issues}

- 2021-08 Addressing social desirability bias in child labor measurement : an application to cocoa farms in Côte d'Ivoire

by Marine JOUVIN

- 2021-07 Environmental policy and the CO2 emissions embodied in international trade by Koutchogna Kokou Edem ASSOGBAVI, Stéphane DEES

- 2021-06 Global Account Imbalances since the Global Financial Crisis: Determinants, Implications and Challenges for the Global Economy

by Koutchogna Kokou Edem ASSOGBAVI

- 2021-05 A method to reduce false positives in a patent query

by Johannes VAN DER POL, Jean-Paul RAMESHKOUMAR

- 2021-04 Extending A Regional Innovation Network: A Technology Intelligence Approach by Johannes VAN DER POL, Jean-Paul RAMESHKOUMAR, Sarah TEULIERE, Thierry BAZERQUE

- 2021-03 Introducing Environmental Ethics into Economic Analysis: Some insights from Hans Jonas' Imperative of Responsibility

by Damien BAZIN, Sylvie FERRARI, Richard B. HOWARTH

- 2021-02 The missing link: international migration in global clusters of innovation

by Massimiliano CODA-ZABET'TA, Christian CHACUA, Francesco LISSONI, Ernest MIGUELEZ, Julio RAFFO, Deyun YIN

- 2021-01 The Impact of Services Trade Restrictiveness on Food Trade

by Amara ZONGO

- 2020-21 Zero Rating, Content Quality and Network Capacity

by Emmanuel LORENZON

Ion LAPTEACRU and Ernest MIGUELEZ are the scientific coordinators of the Bordeaux Economics Working Papers. The layout and distribution are provided by Cyril MESMER and Julie VISSAGUET. 